\title{
'Be(com)ing' Ngāti Kahungunu in the Diaspora: Iwi Identity and Social Organisation in Wellington
}

\section{Christina M. González}

A thesis submitted in fulfilment of a Master of Arts (MA) in Māori Studies

Victoria University of Wellington

Te Whare Wānanga o te Upoko o te Ika a Māui

2010 


\begin{abstract}
Ngāti Kahungunu is an ideal example to investigate the processes of identity management and socio-political representation within and outside of their traditional tribal territory. It is the third most populous iwi in Aotearoa/New Zealand, with approximately 60,000 members, and boundaries that span from the Wairoa district down to the Wairarapa region. Kahungunu's complexity and dynamism are not restricted to its territorial boundaries. A large portion of Kahungunu members form expatriate tribal communities located beyond their tribal district.

The Wellington region hosts the largest number of Kahungunu members dwelling outside of their tribal territory, as well as the Ngāti Kahungunu Embassy. The Embassy is an organisation which, like many other expatriate Māori tribal bodies, faces the challenges of locating and reaching its tribal members to connect them to their Kahungunu home and heritage, while simultaneously representing their particular, Wellington-specific voices. This thesis explores the ways that Ngāti Kahungunu identities are articulated, maintained and transformed by individuals and institutions in Wellington today, by analysing qualitative interviews with ten Kahungunu men and women, and a case study on the Kahungunu Embassy.

Three chapters on iwi identity, home and social organisation illustrate how Kahungunu voices in Wellington can more adequately be heard, and their experiences included, in the tribe, despite their apparent geographic and cultural distance. A range of theoretical tools, including Diaspora theory, urban indigeneity, translocalism, flexible notions of home and belongingness to group, as well as cultural concepts grounded in Māori epistemology, such as whakapapa, are useful to reflect upon diverse ways of belonging to community and to place(s). I argue that many Kahungunu in Wellington extend and expand the meaning of 'be(com)ing' Kahungunu through introducing the concept of a 'third space of forms'. The semantic expansions of identity, home and social organisation can inform the purpose and direction of groups, like the Kahungunu Embassy, to better reflect the lived realities of its members.
\end{abstract}




\section{Acknowledgements}

This thesis is dedicated to my interviewees - my friends - and their tīpuna. Each one of your journeys is valid. Each one is beautiful.

In beginning my thanks, I feel compelled to summon the Māori proverb, "Ehara taku toa he toa takitahi; engari, he toa takitini": 'My strength is not my strength alone; it is the strength of many'. This work is the result of the hard work and contributions of the many people I've encountered along my journey. Whether large or small, direct or indirect, everyone's input was significant and all equally appreciated.

Firstly, I give an immeasurable amount of thanks to my partner Futa for all of his challenging, insightful comments, his unyielding support, and for believing in me, even when I didn't. Futa, you were invaluable for listening during the difficult stages of crisis, in the joyous moments of revelation and through the mumbling spaces in-between. I could have not done it without you. Loves!

To my supervisor, Dr. Maria Bargh, mana wahine, thank you for giving me the freedom to think and write the way I do. Your feedback, honesty, patience, positivity, generosity, guidance and counsel made the work possible. I could have not asked for a better supervisor.

I humbly thank my mentor, Dr. Roger Maaka, who has been an excellent example of scholarship, service, humility and kindness. Thank you for welcoming me into parts of your world and for touching me with pieces of your life. I feel that this thesis belongs to you.

I deeply appreciate all the aroha and support from the whānau at Te Kawa a Māui and Te Herenga Waka Marae, especially from VUW staff and students: Peter Adds, Dr. Ocean Mercier, Dr. Alice Te Punga Somerville, Meegan Hall, Paul Meredith, Monoa Taepa, Piri Sciascia, Te Atawhai Kumar and Erin Keenan.

Thank you to the lovely people at the Kahungunu Embassy, specifically Bill Te Huia Hamilton, Tere Harrison and Kathie Irwin; and, to Doreen Christie of Ngāti Kahungunu ki Tamaki Makaurau. Tīhei Kahungunu!

To my angels, Pania, Domenica, Jorgette, Pauline, Willy-John, Hiirini, Dara and Kahu, thank you guys for rejuvenating my spirit and for keeping my mind (relatively) sane throughout the journey.

Thank you to Fulbright New Zealand for being my ticket into this amazing country and for supporting my work. Thank you to its staff and in particular to Mele, Keri, Kara and Andy, and to my fellow Fulbrighters who have become life-long friends, Lauren and Siobhan. 
Thank you to VUW's Scholarship Office for the financial support to do this thesis, to VUW's Financial Support and Advice Services for the extra help when needed, and to my Internal Grants Manager for the funding to attend the AIATSIS National Indigenous Studies conference.

Thank you to Belinda Borell and Evan Poata-Smith for your time, interest and support, especially at the beginning stages of the thesis. Although our conversations were few and brief, they were important to me nonetheless.

Thank you to the 'Ofamo'oni-Lynch family, and especially to Ann, who made my last few months as comfortable and stress-free as possible.

Last, but far from least, thank you to my loving parents, Ramona and Michael, who hold two halves of my heart. And, thank you to my family in general who always support me and my ambitions, even when they involve me moving to the other side of the world. I love you guys with all my Being. 


\section{Table of Contents}

Abstract i

Acknowledgements ii

Table of Contents iv

Chapter One: Introduction 1

I. Preamble - Genealogy of a Thesis........................................................................................................1

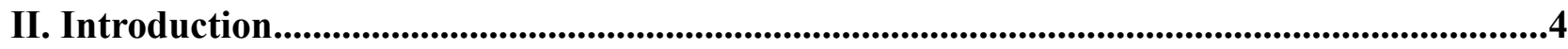

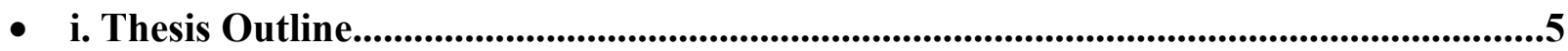

- ii. Consequences of the Thesis.................................................................................................7

$\begin{array}{ll}\text { Chapter Two: Methodology } & 9\end{array}$

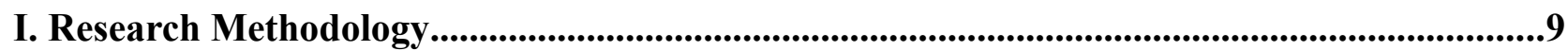

• i. Kaupapa Māori...............................................................................................................................................10

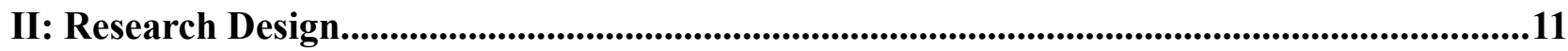

- i. Interdisciplinarity and Māori Studies..............................................................12

- ii. Pre-Interview Process.........................................................................................................................13

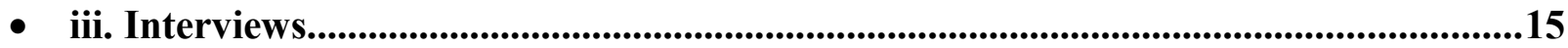

- iv. Post-Interview Analysis.....................................................................................................17

III: Insider/Outsider Positionality ..............................................................................................................17

Chapter Three: Identity $\quad 20$

I. Ngāti Kahungunu: Constitutions of an Iwi Identity..............................................................20

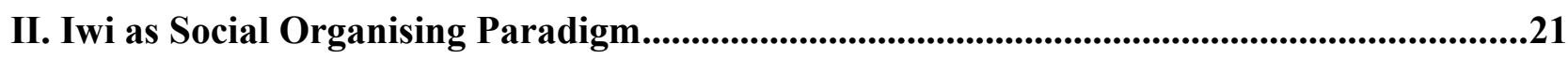

- i. The Kahungunu Project: Post-Contact Constructions of Ngāti Kahungunu Iwi in the

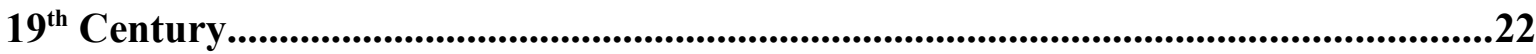


- ii. The Kahungunu Project: Contemporary Constructions of Ngāti Kahungunu Iwi in

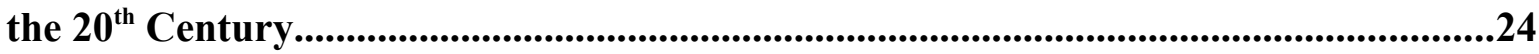

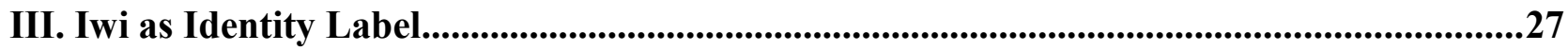

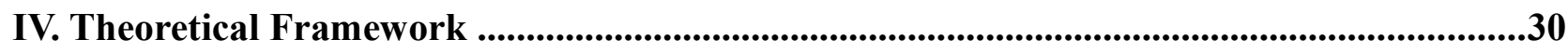

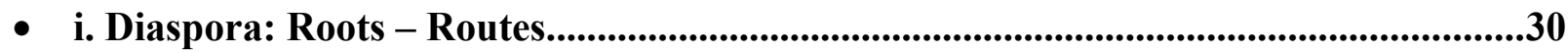

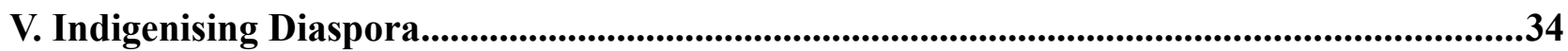

1. Indigenous and Diaspora..................................................................................................................35

• ii. Māori and Diaspora.......................................................................................................................37

VI. Māori Diaspora in Aotearoa/New Zealand....................................................................................38

- i. Kahungunu in Wellington...............................................................................................................39

- ii. "My identity is my family and my home and where I belong".................................41

- iii. Kahungunu Identity in Wellington...................................................................................42

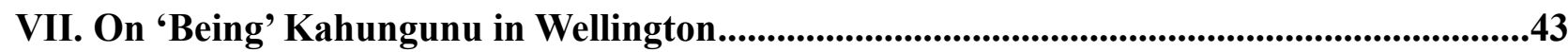

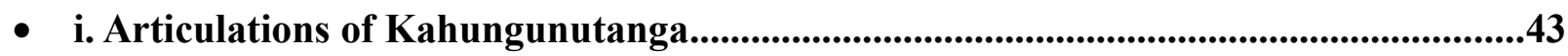

- ii. 'Being' Kahungunu in the Work Place.....................................................................................46

- iii. 'Being' Kahungunu: Manuhiri or Tangata Whenua?...................................................48

VIII. On 'Not Being' Kahungunu in Wellington...................................................................................51

- i. Kahungunutanga from the 'Inside', 'Outside' and 'Side-line'.......................................51

- ii. Kahungunu Identity to Kahungunu Difference..............................................................55

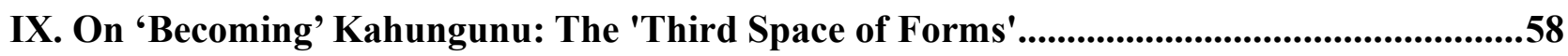

\begin{tabular}{ll} 
Chapter Four: Home & 63 \\
\hline
\end{tabular}

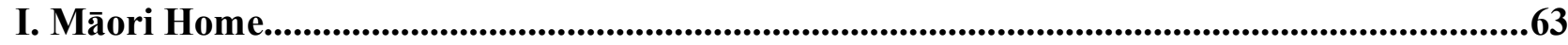

- i. Roots of Home: Ahi Kā (Roa).............................................................................64

- ii. Home of Roots: Tūrangawaewae......................................................................................68

- iii. Home Beyond Roots: Tribal Māori in the Diaspora.........................................................70 


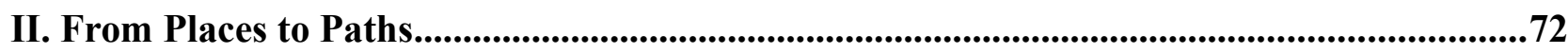

- i. Exploring the Dichotomy of Spatial Roots and Routes................................................72

- ii. Exploring the Intersection of Spatial Roots and Routes..............................................74

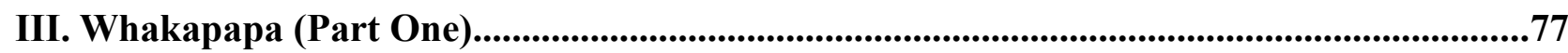

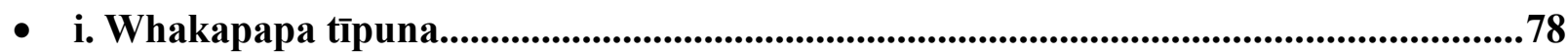

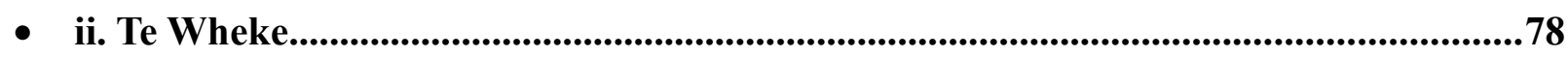

- iii. Whakapapa of Experience..................................................................................8

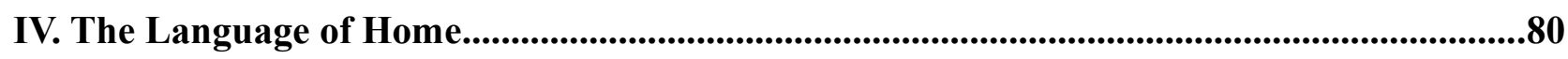

- i. Terminological Sensitivity and Locational Specificity of Home.................................81

- ii. Power and Implications of Naming: Wellington and Te Whanganui-a-Tara............85

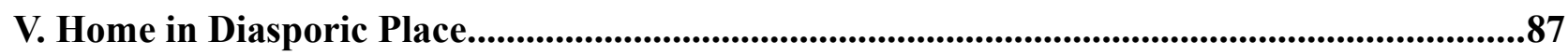

- i. Dimensions of Wellington as Home...............................................................................8

- ii. Home is in the People: Whanaungatanga and Translocalism...................................91

VI. Home in Kahungunu Place: Connections and Reconnections................................................94

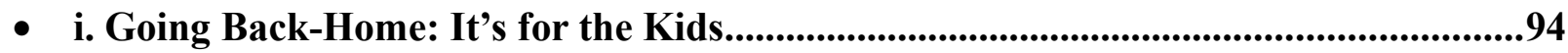

- ii. Going Back-Home: When the Time is Right............................................................96

- iii. Going Back-Home: Tūrangawaewae and Kaitiakitanga.........................................99

- iv. Going Back-Home: Experiences with and Responses to Being 'Othered'..............101

VII. Home Outside of Kahungunu Place...........................................................................105

- i. Entertaining the Role of Global Routes........................................................................105

- ii. "No Hau e Wha": The Home that Travels......................................................................106

- iii. Reconciling Home Roots with Home Routes...........................................................108

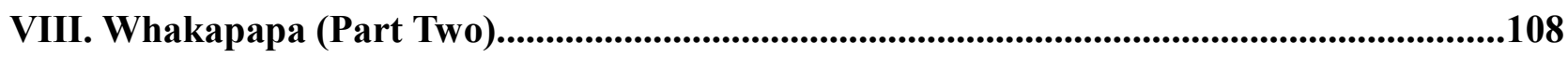

- i. Whakapapa of Place and Whakapapa Tūrangawaewae..............................................109

- ii. Whakapapa, 'Critical Thirding' and the 'Third Space of Forms'..........................109 
IX. Final Statements on Home.....................................................................................................................110

$\begin{array}{ll}\text { Chapter Five: Social Organisation } & 111\end{array}$

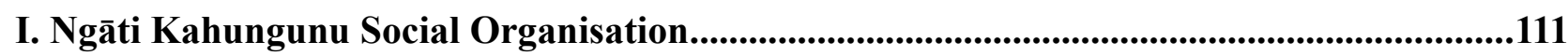

- i. Ra Waho: Tribal Organisation in the Domestic Diaspora.............................................112

- ii. Taurahere Rūnanga: Kahungunu Outside of Kahungunu..........................................115

II. Te Rūnanga o Ngāti Kahungunu (TRONK) ki Te Whanganui-a-Tara..................................115

- i. TRONK ki Te Whanganui-a-Tara: Strategic Relationships.....................................116

- ii. TRONK ki Te Whanganui-a-Tara: Membership Database.......................................117

- iii. TRONK ki Te Whanganui-a-Tara: Communication...................................................118

III. TRONK ki Te Whanganui-a-Tara: Iwi Representation...............................................119

- i. The Kahungunu Project Today: NKII and Iwi Nation-Building..................................119

- ii. TRONK ki Te Whanganui-a-Tara: Kahungunu Embassy...........................................122

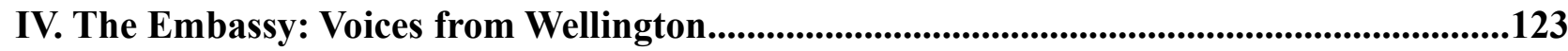

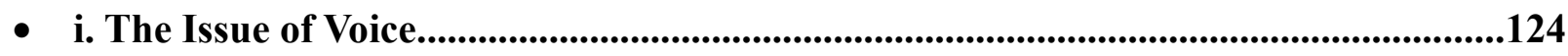

- ii. The Issue of Roles..........................................................................................................125

- iii. A Kahungunu Place-to-Stand in Wellington................................................................127

- iv. Staying Tribally-Connected: The Rope that Binds without the Embassy...............128

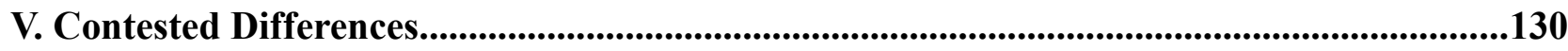

- i. Kahungunu Social Organisation: Reality in Locality.............................................130

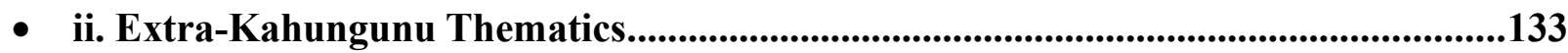

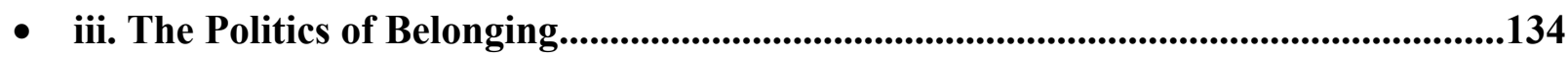

VI. Tension of Voice: Possible Resolutions..........................................................................139

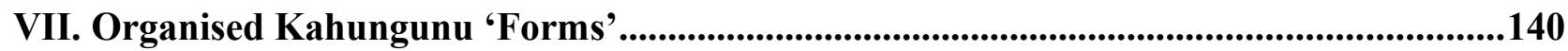

$\begin{array}{ll}\text { Chapter Six } & 141\end{array}$

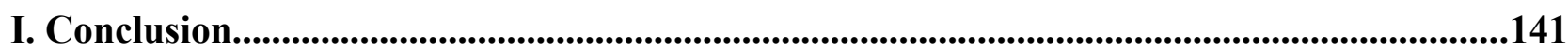




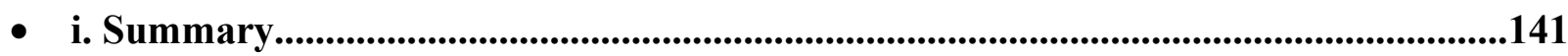

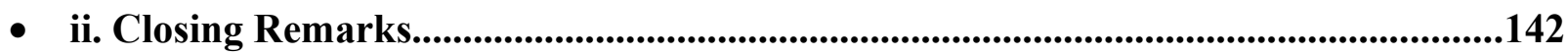

\begin{tabular}{ll} 
References & 143 \\
\hline
\end{tabular}

Appendices $\quad 156$

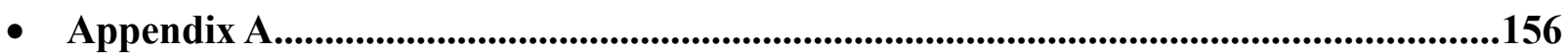

- Appendix B.................................................................................................................................157

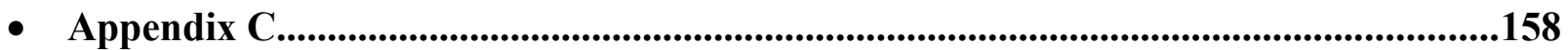

- Appendix D.................................................................................................................................................160

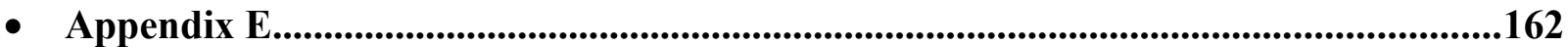




\section{Chapter One: Introduction}

\section{Preamble - Genealogy of a Thesis}

I vividly recall my adolescent-self marinating in deep gazes of longing across an orange-hued horizon and out into the setting autumn sun. My head is uncomfortably ejected outside the protective bars of my uncle's apartment window in the Grand Concourse area of the Bronx, New York, where my sturdy stares breeze by the evening traffic below and the collection of sneakers hanging from power-posts parallel to my vision. All the sights and sounds of the concrete jungle move to the periphery as I take my daily after-school journey to my Caribbean home of Puerto Rico ${ }^{1}$. I am seven years old and deeply nostalgic for a land only previously experienced in infancy.

However physically distant Borinquen was and is from my family and I in New York, as an adult it remains a place, an idea, a home that conjures strong sentiments of loyalty and belonging, making it very real, very near, and very present. Yet, as I am influenced by the rhythmic rotations of my Boriqua culture, I am also, by default, a product of my immediate milieu - a multicultural, urban-pocket existing within a predominantly English-speaking, Anglo-American society. For New York-based Boriqua, also known as Nuyoricans ${ }^{2}$, our cultural pride and socio-historic status as colonised, immigrant and minority impel us to retain strong connections to a Boriqua sense of self $\mathrm{f}^{3}$, while simultaneously having it informed and interpreted by our domiciliary settings and

1 Puerto Rico is an island-nation situated in the Greater Antilles of the Caribbean Sea. It is the oldest colony in the world, with 400 years of Spanish subjugation followed by over 100 years of continuing political, economic and social control by the United States of America through the over-extended status of 'Free Associated State'. The original name of Puerto Rico is Borinquen/Borik'n, loosely meaning, 'Land of the Brave and Noble Lord'. A person who is Puerto Rican, thus, is Boriqua/Borik'a, as having originally come from Borinquen/Borik'n. 'Puerto Rican', 'Boriqua' and 'Borik'a', as well as 'Puerto Rico', 'Borinquen' and 'Borik'n' are used here interchangeably.

2 Although the term 'Nuyorican' originally meant New York-based Boriqua, it has come to identify Stateside-dwelling Puerto Ricans, whether in New York or elsewhere in the USA. Perceived as a negative label to some, others celebrate and use the term (myself included) to mark and acknowledge the socio-historic and environmental influences that make us different from Puerto Ricans on the island.

3 Although broadly (mis)perceived as an ethnic group within the United States, Puerto Ricans are the products of more than 500 years of miscegenation, largely between Iberian (Spanish), West African (Yoruba), and Ameri-Indian (Taino). I am a living physical, cultural and sentimental fusion of these ethno-spheres that for me capture a very personal (but still widely shared) sense of Boriqua identity. 
diasporic conditions. My identities as Boriqua and New York-American, while separate and unique, are also inter-dependent as they mutually contribute to forming me.

My exposure to indigeneity began at a young age ${ }^{4}$. It developed over school meals with friends who would identify their tribal roots, summer powwows attended with Dad, and publicly vented frustration over the mainstream education system's misrepresentation or omission of Native American history in the school curriculum. My personal indigeneity ripened into my university days of volunteering at the United Nations Permanent Forum on Indigenous Issues. There I became aware of the work being done by New York-based Taino seeking to revive our language, protect ancestral sites on Borik'n and educate our people on Taino-specific influences on contemporary Boriqua culture.

My Bachelor degree in Political Science and Latin American/Latino Studies from Fordham University, and my study in and tour of Latin America were purposeful attempts at garnering knowledge absent from my formal public-school education ${ }^{5}$. My sensitivity to the social plights and exploitations of Boriqua and other Latinos through Hispanophone colonialism and American neo-colonialism activated my spirit of resistance and communal empowerment. Consequently, my life voyage has engendered a committed quest to building global relationships and networks of solidarity between colonised peoples to know what shapes us and to develop towards reaching our fullest potential while living better as ourselves.

In 2008, I came to Aotearoa/New Zealand on a Fulbright scholarship to conduct research on how Māori identity and culture are experienced by those leading their lives in urban places, outside of their traditional tribal domains. Due to my personal and international experiences, I felt a pressing need to highlight the conundrum that urbanplaced Indigenous peoples contemporarily are in: the crossroads walked daily between

$4 \quad$ Implicit in the term 'indigeneity' is the politicisation of Indigenous peoples' status as the first peoples of places colonised, and of their continuing struggles for self-determination, autonomy and/or shared sovereignty with the nation-states formed upon their lands (Maaka and Fleras 2005). Keeping in mind the contentious nature of the term 'indigenous' (Clifford 2007:198), in this thesis it is intentionally capitalised to broadly imply the colonised first peoples of the modern world who choose to claim it as an identity. Nonetheless, I do try to be more specific than 'Indigenous' by employing particular local names when applicable.

5 While studying Indigenous legislation in Chile I interned with an urban Mapuche non-governmental organisation in Santiago where I witnessed the difficulties in legislating Indigenous rights, partly because of internal rifts within Mapuche communities - namely between those representing either the city or the rural expereince. 
old and new, tradition and modernity, essentalism and pluralism, cultural retention and transformation, group cohesion and fragmentation. The juxtaposition of Indigenous cultures, striving to maintain degrees of age-old tradition whilst living in the spatial epicentre of modernity - the city - are seldom addressed in academia despite being current and frequently experienced, and despite their (potentially) transformative consequences $^{6}$. My research hoped to uncover the ways in which those who self-identify and coalesce under the banner of 'urban Māori' are represented as valid partners of the Treaty of Waitangi ${ }^{7}$. However, because Wellington lacks urban Māori socio-political organisations $^{8}$, I sought instead to comprehend the urban Māori experience through the culture of tribal-specific satellite groups in the capital-city.

My internship with Ngāti Awa ki Pōneke (NAKP) exposed me to the intentions of and predicaments faced by diasporic tribal communities in the city ${ }^{9}$. One such challenge for NAKP was in locating their tribal members for the purposes of registration and membership to Te Rūnanga o Ngāti Awa. Despite reportedly having a large number of members living in Wellington ${ }^{10}$, NAKP had only a fraction of registrants ${ }^{11}$. In mid-2008, I conducted a scoping paper for the ex-chair of NAKP Sir Hirini Moko Mead, making recommendations on how to seek out and locate Ngāti Awa people residing in Wellington. In the end, the impression the research left me with was of a need for greater

$6 \quad$ In my current journey, I endeavour to understand these grey and murky parts of identity; the production, development, activation and entanglement of our different, multiple selves. The purpose of gaining and sharing knowledge on the contemporary, dynamic nature of our identities is an expression of self-determination. It is an exercise in naming, writing and owning the experiences that shape us presently while guiding us into the future.

7 The term 'urban Māori' in many instances is a misnomer since it does not only apply to Māori who reside in a city-like environment, but is used to identify Māori who have become culturally 'disconnected' or who lack conventional markers of Māori identity, those including communicative skills in the Māori language, active participation in marae life, or even a solid knowledge of one's whakapapa (Borell 2005; Maaka and Fleras 2005; McIntosh 2005).

8 More specifically, Urban Māori Authorities, the likes of which are found in Auckland with Waipareira Trust and Manukau Urban Māori Authority.

9 I interned with NAKP from September to November 2008 through an Honours paper at VUW's Māori Studies Department under the supervisory guidance of Dr. Maria Bargh.

10 The 2006 New Zealand Census reported that 1,053 Ngâti Awa live in the Wellington region (Statistics New Zealand 2006:33); approximately 250 were registered with NAKP in 2008.

11 Perhaps one of the reasons Ngāti Awa in Wellington did not register with NAKP is because according to the 2005 Ngāti Awa Charter people are to be registered in the Ngāti Awa database under one hapū (2005:32). NAKP is a legally recognised hapū under the Ngāti Awa constitution (2005:56). As a result, Ngāti Awa who reside in Wellington are faced with the predicament of registering to the hapū in which they whakapapa to or the hapu for the area in which they domicile. Many possibly register to the former. 
understanding of how tribally-affiliated Māori are living, identifying and organising outside of their tribal domains. In the case of Ngāti Awa people, did they see themselves as primarily Ngāti Awa who happened to live in the city, or as Wellingtonian (or Māori in general) who just happened to be of Ngāti Awa descent? I concluded that further research could shed light on the purpose and role urban-based tribal groups (can) have on their affiliates, by providing community-informed data on the consequences of living in Wellington, away from one's tribal-home ${ }^{12}$.

\section{Introduction}

Ngāti Kahungunu $^{13}$ is an ideal example to investigate the processes of identity management and socio-political representation within and outside of their traditional tribal territory. As the third most populous iwi in the country, with approximately 59, 946 affiliates, Kahungunu are nine percent of New Zealand's total Māori population (Statistics New Zealand 2008:1). It is a territorially diverse tribe whose boundaries span from the Wairoa district along the North Island's North-East coast down to the Wairarapa region in the South-East (see Appendix A). Ngāti Kahungunu is an accumulation of varying iwi and many hapū with common descent or connections to the eponymous ancestor, Kahungunu. As an iwi, it is profoundly complex and richly dynamic, consisting of many geographically dispersed and socio-historically divergent groups that constitute parts of a larger supra-iwi structure and ideological whole.

Kahungunu's complexity and dynamism are not restricted to its territorial boundaries. A large portion of Kahungunu members form part of an expatriate community, residing in areas beyond their Kahungunu tribal district, around Aotearoa ${ }^{14}$. Outside of the Hawke's Bay region, which has the heaviest concentration of Kahungunu at 17,043 (28.4\%), the Wellington region hosts the second largest number of Kahungunu members, 9,759 (16.3\%) (Statistics New Zealand 2006:33). For Kahungunu who have inherited or made

12 In researching for the NAKP scoping paper, I looked to methods other urban-based iwi groups used to contact their members. I soon realised that the issues NAKP faced were not particular to them, but were shared by other expatriate iwi groups.

13 'Ngāti Kahungunu' and 'Kahungunu' will be used interchangeably throughout this thesis. It will be dependent on the context as to whether I am referring to a Kahungunu person, people, group or social organisation.

$1464 \%$ of Kahungunu descendants live outside of the Kahungunu tribal area (Te Puni Kōkiri 2009:25). 
Wellington their home-away-from-home, their relocated or mobile state propels them to constantly navigate between two worlds. This thesis asks: how are manifestations of Ngāti Kahungunu identity articulated, maintained and transformed by individuals and institutions in Wellington today? It intends to demonstrate that some Kahungunu in Wellington uniquely experience and express their Kahungunu cultural identity, reflecting the dynamics of their spatial belonging and socio-historic context.

\section{i. Thesis Outline}

Currently, understandings of Kahungunu identity and belongingness could be expanded to accommodate for the diversity of experiences lived. Throughout this thesis, I analyse Kahungunu intra-tribality in Wellington to frame the ways Kahungunu traverse the ambiguities of their iwi identity. This will be done from two primary levels of experience: the micro-level of Kahungunu individuals - informed by my interviewees, and the macro-level of a Wellington-based Kahungunu institution - namely, the Kahungunu Embassy. The purpose of the two different levels of focus is to capture the multi-sited nature of Kahungunu culture and identity, and to demonstrate how the social realities of Kahungunu people can inform organised Kahungunu groups.

Beyond this first chapter, which situates the work, Chapter Two explains the thesis methodology before further exploring the themes of subsequent chapters. My methodology adopts a multi-tiered approach to an interdisciplinary investigation grounded in Māori Studies. In researching social reality, I believe methodology should be as dynamic as the experiences of those the work seeks to reflect. Thus, I employ qualitative and quantitative methods, critical theories coupled with Māori research

paradigms, as well as supporting literature that spans Cultural Studies, History, Geography, Anthropology, and Political Sociology. However, life-focused, qualitative interviews with ten Kahungunu, as well as a case study on the Kahungunu Embassy, act as my primary sources.

While Chapter Two elects the tools used to engineer the thesis, Chapter Three lays down its foundation. This chapter explores the notions of 'being' Kahungunu, 'not-being' Kahungunu and 'becoming' Kahungunu, outside of Kahungunu territory. It seeks to demonstrate the diversity of Kahungunu and how some extend and expand their cultural identity in Wellington. Chapter Three argues for the consideration and equal privileging 
of Kahungunu differences in constructions of Kahungunu unity. To accommodate for the synthesis of intra-Kahungunu commonalities and divergences, I summon theories from Urban Indigeneity, Diaspora and Articulation ${ }^{15}$, constructing and developing the idea of a 'third space of forms'. My goal is to highlight the flexible notion of Kahungunu 'forms', and to show the significance of intra-Kahungunu differences and their potentially transformative implications for Kahungunu iwi.

Chapter Four investigates the concept of a Wellingtonian identity and how my interviewees enhance notions of home and belonging by living in Wellington. It invokes and expands upon the concept of a 'third space of forms' as applied to cultural identity, and extends it to Māori concepts of home, spatial identity and spatial belonging. The chapter seeks to demonstrate how notions of home in the Kahungunu world can be flexible, complex and context-dependent, by highlighting the multifarious ways some Kahungunu belong to places. It problematises belonging through the binaries of place/space and tribe/diaspora by evoking the notion of translocalism and ideas endogenous to the Māori principle of whakapapa. Additionally, the relationship my interviewees have to where they domicile shows the different ways Wellington can be interpreted: as the capital city, an urban space ${ }^{16}$, non-Kahungunu territory, and the home of other tribes. Chapter Four argues that some Kahungunu in Wellington interpret, engage with and relate to space in dynamic, relational and culturally-specific ways.

Chapter Five fuses and applies ideas from the previous two chapters on Kahungunu identity and socio-spatial connections to Wellington. In this chapter, the Kahungunu Embassy is highlighted as an organised diasporic tribal community attempting to connect Kahungunu in Wellington to a Kahungunu identity and home while still representing the distinctiveness of where they live. The Kahungunu Embassy exemplifies the mediation and balance between intra-tribal cohesion and variation, and could potentially be an innovative attempt at collectively embodying the 'third space of forms'. This chapter delves into issues of representation and the challenge of involving more Kahungunu in

15 Articulation theory (introduced at the end of Chapter Three) is not to be confused with my use of the word 'articulation(s)'(non-capitalised) throughout the thesis which acts mostly as a synonym for 'expression(s)'.

16 Statistics New Zealand defines 'urban' according to population dwellings, requiring a minimum population of 30,000 (2001:5). There are four main urban areas in Wellington that centre around: Wellington city, Porirua city, Lower Hutt city, and Upper Hutt city. 
the Embassy. As in previous chapters, it invokes the idea of flexible notions of belonging, and applies them to organised community. Chapter Six provides a summary of my findings and ends with concluding remarks.

\section{ii. Consequences of the Thesis}

Research on Kahungunu identity in Wellington can be useful for the intentions of Kahungunu institutions that wish to remain connected with their dispersed populations and understand the ways in which living away from home impacts upon their iwitanga, or 'iwiness'. Not only does this thesis provide insights into some Kahungunu realities in Wellington, it does so with purpose; voices that may otherwise go unheard are acknowledged, reflected upon and responded to. Additionally, this research may help inform discussions that see the 'urban' or 'diasporic' Kahungunu situation negatively - as experiences that 'disconnect' Kahungunu members from a tribal identity, home and sense of belonging. Instead, their realities may add to understandings of the complexity and dynamism of iwi identity today. In fact, iwi identity, home and organisational paradigms could broaden to encompass the constant and fluid nature of some people's lives. I hope this thesis helps show how some Kahungunu reconcile the commonalities of their identity with the dissimilarities of their experience, and consequently demonstrate how they all are valid manifestations of 'be(com)ing' Kahungunu.

Finally, why should a Boriqua from New York City come to Wellington, Aotearoa/New Zealand to write a Masters thesis on Ngāti Kahungunu identity? The answer may most sincerely be reflected in the Spanish saying: "Soy el otro", or 'I am the other'; as well as, the Māori proverb, "Waiho i te toipoto, kaua i te toiroa" - meaning, 'Let us keep close together, not far apart' ${ }^{17}$. To best understand ourselves as surviving members of a pre-colonial legacy, victims of a colonial history and agents of a countercolonial resistance culture, we must first have a holistic comprehension of what makes us collectively who we are now. The future continuity of our societies is inevitably conjoined to a local-global continuum. We are inextricably linked to the health and progress of each other and of each other's spaces. Through my thesis journey and lifespan in Aotearoa/New Zealand, I hope to not only more thoroughly dissect the ways in

17 Mead and Groove state that this saying implies a need for physical and moral support between people (2001:417). 
which we are shifted, shaped and transformed by the traditions we belong to and the culture of places we domicile in; but, in the process honour that which makes us different whilst strengthening that which makes us same. 


\section{Chapter Two: Methodology}

\section{Research Methodology}

My belonging to a group with experiences of being researched by 'non-allied others' for audiences other than our own has sensitised me to how 'researched others' can be silenced and disempowered. How then do I, as researcher, manage the power relations between myself and my thesis participants, who themselves belong to a marginalised community with a history of being researched by non-Māori and presented to non-Māori audiences? How can I conduct my research as a non-Māori but as an "allied other" (Swadener and Mutua 2008:31) in a methodologically appropriate way to prevent perpetuating power structures that can marginalise my participants and produce disempowering outcomes for Kahungunu? This chapter explains the methodology that guides the direction of this research and the methods, tools and philosophies that inform the course of its journeying.

Any research involving people should take great care in working with and for them; detailed attention should be paid to the way that knowledge is collected - keeping in mind, for what and whose purpose it is gained, framed and shared. In particular, I believe that research on Indigenous peoples should be non-colonising in principle and in practice, allowing for the uninhibited expression of their self-determination. My thesis is a defence of the voices of my Kahungunu participants. It requires a methodology that can sustain that defence as well as contribute to facilitating a space for expansive, inclusive and reflective dialogues on 'be(com)ing' Kahungunu.

Throughout this thesis, I rely on Māori-centred, qualitative methodology and Māoribased epistemology paired with critical theories to investigate how some members of Ngāti Kahungunu experience and express their Kahungunu identity in Wellington today. I evade a search for a single notion of universalised truth based upon objectivity as evidence, and work instead from the post-modern/post-structural positions that there are "multiple ways of knowing, depending on whose lens is used" (Dunbar 1999:96). Through centring a multiplicity of subjectivities, an assortment of experiences and perspectives on Kahungunu identity form the basis of knowledge-making and truthtelling. The aim for me as researcher becomes to balance shared ways of knowing 
between my participants and the commonalities in their stories without compromising the distinctiveness of voice and the particularity of experience.

\section{i. Kaupapa Māori}

Kaupapa Māori, or Māori-centred research privileges Māori philosophy, values, traditions, ways of knowing, ways of doing and ways of being (Bishop and Glynn 1999; Cram 2001; Morseu-Diop 2008; Smith 1999). As a form of Indigenous qualitative research, it best captures the strategic direction of my methodological journey ${ }^{18}$. Although I am not Māori, I support and work towards the larger aims of Kaupapa Māori research to empower Kahungunu and contribute to their self-determination. My process of data collection is informed by Māori cultural protocols that Smith adopts as ethical research guidelines for Māori researchers:

1) Aroha ki te tangata (respect for people);

2) Kanohi kitea (the importance of meeting face-to-face);

3) Titiro, whakarongo ... korero (look, listen ... speak);

4) Manaaki ki te tangata (be generous, share and host people);

5) Kia tupato (be cautious);

6) Kaua takahia te mana o te tangata (do not trample the mana of the people);

7) Kaua e mahaki (do not flaunt your knowledge) (Smith 1999:120).

Although Smith also outlines culturally safe practices for non-Indigenous researchers to use with Indigenous communities ${ }^{19}$, I approach those strategies from a cross-cultural perspective $^{20}$.

18 I borrow from Belinda Borell's use of Kaupapa Māori on a strategic level. In her work on rangatahi Māori identity in South Auckland (2005) she is cautious in deploying Kaupapa Māori on an operational level. She problematises a Kaupapa Māori project that relies heavily on quantifying Māori culture which she explains can lead to alienating Māori who lack the conventional markers of that identity (2005:39-40).

19 In the case of Māori, Smith suggests that the non-Indigenous researcher become knowledgeable about Māori concerns and consult with Māori to gain their consent and support for research concerning them (Smith 1999:177).

20 Although Smith outlines protocols for Indigenous and non-Indigenous researchers to use in working with Indigenous communities, my own indigeneity does not warrant me immediate acceptance into Māori communities; nor does it grant me the mandate to conduct Māori-focused research without Māori approval and supervision. Consequently, I conduct my work in a cross-cultural context, taking extreme effort to be led and directed by Māori regarding questions to ask and procedures to use that are appropriate to this research. 
Since my arrival to Aotearoa/New Zealand, I have endeavoured to learn (as best I could) about Māori from Māori, their histories, cultures, traditions, value systems and language from within academic circles, social settings that welcomed me, and friends. I spent most of 2008 amongst Māori people, forming friendships and relationships of solidarity founded upon mutual interest, understanding and growth. Coincidentally, that same year provided me with a basic foundation in and exposure to the issues concerning some Māori - those addressed in this thesis. My aims and approaches have been monitored and supported by Māori academics and leaders, and the types of questions asked within this thesis developed in conjunction with my supervisor and mentor. The strategy of mentor-seeking in the development of my research is referred to as 'tiaki' and is one of four research models proposed by Māori educator Graham Smith for nonIndigenous researchers (Smith 1999:177).

\section{II: Research Design}

This project is largely a qualitative practice framed within a multi-method research design. Methodological polytheism (Wacquant 1992:30), multiple triangulation (Arksey and Knight 1999:22) and interdisciplinarity (Lattuca 2001) encourage the use of a variety of methods and theories to best reflect the particular issue in question and to capture a more 'complete' form of research. In the same way that social reality is multi-faceted and complex, the methods used to unravel and reveal it could also be varied and layered. Thus, the methods and theories summoned for this work are all of sorts and kinds and are tailored specifically to my chosen questions and processes of investigation ${ }^{21}$. The methods employed for this study include:

- In-depth, life-focused, semi-structured interviews with ten Kahungunu;

- Questionnaires with (potential) interviewees;

- Informal conversations with interviewees and non-interviewees ${ }^{22}$;

- Observation and participation at the Kahungunu Embassy and Kahungunu events I was invited to;

21 Because different methods can elicit different outcomes/inputs, they should be deliberately chosen, carefully deployed and critically reflected upon (Bourdieu and Wacquant 1992:20).

22 These conversations were not purposefully part of the research, but nonetheless penetrated my subconscious and worked to influence the direction of my inquiry and develop my thoughts further. 
- A case study on the Kahungunu Embassy.

Methods that developed external to this thesis but that contributed to it nonetheless, include and are not limited to: informal and formal classes in Māori Studies at Victoria University of Wellington (VUW), my time on Te Herenga Waka Marae at VUW, my internship with $\mathrm{NAKP}^{23}$, and four conferences attended involving issues on contemporary Māori identity.

\section{i. Interdisciplinarity and Māori Studies}

As my methods try to capture the complexities of Kahungunu realities, so too does my use of disciplinary knowledge, language and theory. This project has its heart firmly rooted in Māori intellectual traditions and the Māori cultural world. Yet, at the same time its limbs occupy the cultural space of more than one discipline. Indeed, "social research is something much too serious and too difficult for us to...deprive ourselves of this or that resource available in the full panoply of intellectual traditions" (Bourdieu 1992:227). My project is interdisciplinary in that it borrows methods and theories from a number of disciplines $^{24}$, provided they function as the most appropriate vehicles to address the questions posed. Usually it is the type of questions asked that informs the disciplinary frame and tools used in research. Yet, as Lattuca explains, the advantage of interdisciplinarity is that "it enables the use of a variety of tools and prevents researchers from trying to shape problems to fit disciplines" (2001:107). A benefit to using interdisciplinarity in this project is that theoretical tools from varying disciplines can be summoned to expound upon and complement my participants' experiences of their Kahungunu identity. Interdisciplinarity in a Māori Studies context can offer the "prospect of new articulations of lives, lands, identities, voyages, genealogies, histories, societies, cultures, languages, knowledges, and epistemologies" (Whimp 2008:414; my own emphasis).

Māori Studies provides a culturally appropriate space that can challenge the rigidity of disciplinary fields. Many social science disciplines can be seen by researchers as 'distinct' domains of knowledge all seeking to claim themselves as superior routes to quantifying human reality and the social world into a single, unified truth (Alasuutari

23 Please see Chapter One for further information.

24 See Chapter One. 
2004). While Māori Studies positions Māori culture, knowledge and values at the centre of investigation and representation - what Whimp refers to as "indigenous location" (2008:398) - it can also be a bridging point between theoretical and disciplinary multiplicity. Māori Studies has the "flexibility to incorporate methods, theories, and approaches to research from many different disciplines that are conducive to the Indigenous research context" (Innes 2009:440-441). My research depends on Māori Studies to support my responsibility to the Kahungunu world and allow me the freedom to work across schools of thought, provided they relate to, accurately reflect, and positively contribute to Māori social realities.

\section{ii. Pre-Interview Process}

In September 2008, I received ethics approval from VUW to conduct interviews regarding experiences of urban indigeneity from Wellington-based Māori (see Appendix B). Ethics consent confirms my project is designed to protect the rights of the people involved, and assures it is sensitive and attuned to Maori cultural values in the research process. Between August and November 2009, I conducted ten in-depth, life-focused interviews with five males and five females, ranging from 25 to 63 years of age, and coming from a variety of professions, those including but not limited to scientist, performance artist, librarian, entrepreneur and full-time tertiary student. For (potential) interviewees, I required that they: one, self-identified as being of Ngāti Kahungunu descent, and two, (had recently) resided in the Wellington region ${ }^{25}$. I believe both requirements to be self-explanatory in their relevance for this research and in their functioning as basic and broadly shared identifiers amongst participants ${ }^{26}$. No additional preferences beyond the aforementioned were required of my interviewees ${ }^{27}$.

25 Only one of my interviewees was not living in Wellington at the time of the interview, but she had only just moved a couple of months before and had spent more than five years in Wellington prior to relocating.

26 Initially, I debated whether or not to focus on those who self-identified as Kahungunu and as Wellingtonian. However, I decided against it for fear that such would jeopardise the very nature and intention of the project, which is to capture the fluid and multifarious ways that identity and culture are experienced by those who descend from Kahungunu.

27 Even within the expected criteria, I did not exempt those who may have identified more strongly with another tribal affiliation, nor did I privilege those who were born and/or raised in Wellington from those who moved to the region later in life. These were necessary and deliberate attempts at not limiting the kind of information that would serve useful. While ambitious, it was also a strategic decision that prevented me from filtering and manipulating input to frame a singularised and unrealistic sense of the Kahungunu experience and community in Wellington. 
For practical and cultural reasons, a range of methods were selected in recruiting interviewees that reflect what is known in social science research as "triangulated sampling" (Arksey and Knight 1999:21). Most of my interviewees are friends of mine from VUW or from social circles outside of the tertiary environment. Those interviewees who were not personal friends were introduced to me by friends; thus, a snowball form of sampling was utilised in addition to my initial contacts. In the Māori world, this could be referred to as whakawhanaungatanga, inter-relating with Māori through previously established networks and relationships in culturally appropriate ways (Bishop and Glynn 1999:169). While many of my interviewees did not know each other personally, others did, as they are part of the same social circles to which I myself belong. Yet, the familiarity of interviewees with each other or with me did not impinge upon gaining an information "rich" (Smith et al. 2009:56), heterogeneous sampling ${ }^{28}$. For me, relying on friends as interviewees boded well for conducting Māori-focused research in a culturally safe manner. In choosing friends and friends-of-friends to interview, there was an already established relationship and reciprocated trust - that in many cases, outlasts the timeframe of the research. I feel the awesome responsibility of honouring the mana ${ }^{29}$ of my interviewees, not only as tangata whenua of Aotearoa/New Zealand and participants of this study, but as my friends and people I respect and admire.

A few days prior to conducting the interviews, I requested that participants complete a questionnaire sample of sixteen questions (see Appendix C); nine questions were openended and nine were closed. Included with the questionnaire was an information sheet (see Appendix D) on the project and on the type of themes and questions to be asked. Interviewees were to submit their responses and interest in the research to me in person, through email or by $\operatorname{pos}^{30}$. Open-ended questions ranged from tribal affiliations and places lived domestically and internationally, to closed questions, such as, self-

28 In case of confusion, I would like to clarify that all of the interviews were conducted on a one-on-one basis. In the questionnaire sheet - explained shortly - I asked what kind of interview would be preferred (one-on-one, joint, focus group or no preference). The majority responded 'no preference'. Yet, because the remainder preferred a one-on-one style of interview, I decided to conduct all the interviews in the same fashion.

29 There is no English equivalent to the word 'mana'. However, the words 'prestige', 'power', 'authority' and 'autonomy' loosely convey its meaning.

30 I included a self-addressed stamped envelope for those who preferred to send their questionnaires through postal mail. 
identification as Wellingtonian, and registered membership to Ngāti Kahungunu Iwi Incorporated (NKII) and the Kahungunu Embassy. Although an example of quantitative sampling, the questionnaire sheet helped me prepare for and shape the interviews to the particularities of participants' experiences ${ }^{31}$. The questionnaires also helped me diversify the type of interviews $\mathrm{I} \mathrm{had}^{32}$. This was done to reflect the heterogeneity that characterises Kahungunu people.

\section{iii. Interviews}

Interviews with ten Kahungunu were semi-structured in style and ranged from 60 to 120 minutes. They consisted of mostly open-ended questions, and nine of the ten interviews were divided into four main thematically organised sections ${ }^{33}$ :

1) Kahungunu identity and culture: exposure to, expressions of, and experiences with;

2) Wellington: movement or migration to, growing up and living in, identity and lifestyle of;

3) Home: where is, experiences of;

4) The Kahungunu Embassy: involvement in and opinions of.

Examples of questions asked include:

- How does being Kahungunu influence areas of your life such as work, social life and child-raising?

- How does living in Wellington impact on your Kahungunu identity?

- Where is home and why?

- How often and on what occasions do you travel to your Kahungunu marae?

- Are you involved in the Embassy? Why or why not?

31 For instance, I would not presume to ask a person who I knew was born and grew up in Wellington their experience of migration to the region, as I would not pose questions on being raised in Wellington for one who spent her adolescence in Christchurch, or his in the Waikato region.

32 I purposefully wanted to include some perspectives from people who were not particularly in favour of being deemed 'urban' or 'Wellingtonian' just as much as I wanted to include those who unapologetically self-described themselves as 'urban Māori'.

33 The interview themes and questions were not delivered in a particularly linear, uniform order as their deliverance depended upon the flow of the conversation. For instance, although I may have began with one question, the interviewee would respond, but not without also answering two other questions from another thematic category. 
My interviewees filled-out a consent form (see Appendix E) before each interview, which asked if they agreed to be identified by name in the thesis, and all but one agreed. The person that declined being named chose a pseudonym. During and/or immediately following each interview, I demonstrated manaakitanga for the time and knowledge my interviewees shared by giving koha, food and drink. The koha would vary for each interviewee, but would include a thank you note plus two movie ticket vouchers, a bowling voucher or a bottle of wine. I provided food I knew participants liked, and sometimes I included traditional Puerto Rican food as a demonstration of sharing parts of my own culture.

Chapter Five highlights the Ngāti Kahungunu Embassy as a case study in organised attempts to express and represent a distinctly Kahungunu identity in Wellington. The main tools for this chapter include:

- One focused, semi-structured, qualitative interview with the Embassy's Chairperson, Bill Te Huia Hamilton;

- Interviews with the other nine participants ${ }^{34}$;

- Participant observation at two public Kahungunu Embassy events in 2009;

- NKII website;

- The Kahungunu Embassy online blog;

- $\quad$ NKII pamphlets and newsletters;

- The NKII Constitution.

The interview conducted with Bill Te Huia Hamilton was significant in gaining a perspective on the role and duty of the organisation directly from its current leader and one of its longest-serving members. In his interview, I did not adopt the same thematically-driven features guiding the other interviews because my main objective with him was to focus on his opinions on and work with the Embassy. Questions for this interview included:

- What does the Embassy represent?

- Who does the Embassy speak on behalf of?

Information from their interviews was used, provided they referred to the Embassy or their activities in other organised groups in Wellington. 
- What contributions does/can the Embassy make for Kahungunu in Wellington?

- What can Kahungunu people do for the Embassy and its kaupapa?

\section{iv. Post-Interview Analysis}

My interviews follow Interpretative Phenomenological Analysis (IPA). IPA is an idiographic approach to examining how a phenomenon appears; it is concerned with exploring the experience in its own terms (Smith et al. 2009:1), identifying "specific ways by which the participant talks about, understands and thinks about an issue" (Smith et al. 2009:82). As a hermeneutic exercise, it is "concerned with the dynamic relationship between the part and the whole, at a series of levels" (Smith et al. 2009:28). IPA is useful in investigating Kahungunu experiences in Wellington because it lends itself to the thematic designs of identity, home and social organisation which structure this thesis. Although answers varied between interviewees, thematically-based questions assisted in identifying and weaving together common threads of experience, feelings and thoughts on the subjects concerned. I also employ IPA as a method of inductive reasoning so that the main theory develops from the 'ground up' (Babbie 1998:3) since it is informed by the interviews and my interpretations of them.

The framing of knowledge in this thesis is entirely dependent on the mixture of multiple subjectivities, my own included. Thus, not only am I inherently implicated in making sense of my interviewees' experiences, but information from the interviews is interpreted through the lens of my own biases, perspectives, experiences and interpretations. Brown and Strega add that "subjectivity of the researcher [is] a salient, if not determining, factor in research design and results" (2005:3). However, any final product of this work is not without the approval of my interviewees, especially where it concerns them directly.

\section{III: Insider/Outsider Positionality}

The insider/outsider element is implicit of self-reflexivity in social research today. Since the researcher is unavoidably influenced by his/her own subjectivity, s/he is expected to be cognisant of his/her positionality in the research project, its design, process and outcome(s). Thus, power in the practice of research is highly influenced by 
my occupying the position of 'insider' or 'outsider'. Yet, my experience throughout the research journey transcends an 'insider/outsider' dichotomy because my positionality is layered and contextual. For example, in the interview process, I did not see myself, nor was I treated, as perpetually and only 'insider' or 'outsider'. I am 'outsider' as an American studying in New Zealand, as a postgraduate student conducting academic research, as non-Māori working in a Māori context, and as non-Kahungunu researching issues pertinent to Kahungunu. My interviewees knew this about me and related to me accordingly ${ }^{35}$. But, as much as I occupy multiple 'outsider' positions, I am located within various 'insider' ones, too. For instance, I was engaged with as 'insider' for being a woman and indigenous to Puerto Rico, for being an urbanite, of a marginalised minority group, a locally-focused and global-thinking person, and as a trusted friend and/or confidant. Smith attests that an 'official insider/outsider voice' (1999:139) is problematic as it takes-for-granted the complexities of critical and qualitative research approaches and the mediation that ensues between researcher and community (members). So, "rather than become fixated on who is included and who is excluded" Ladson-Billings and Donner state, "we need to consider the way that we are all border dwellers who negotiate and renegotiate multiple places and spaces" (2008:80). To claim a purely 'insider' or 'outsider' role and accept its inclusionary/exclusionary consequences is precarious, since it hollows my experiences of multiple positioning, as well as all the ways in which my interviewees saw and related to me.

The issue of being 'insider/outsider' in my methodological process echoes what this thesis tries to address on a larger scale - feelings of being included in or excluded from Kahungunu and experiences that can be seen as 'inside' or 'outside' of Kahungunu culture and place. I see this project as an example of cross-cultural, global communication that seeks to engender partnership and growth between myself and my participants. But, it also encourages these things further between Kahungunu people. This thesis attempts to be a dialogue in motion between sameness and difference, unity and division; between the multiple 'us's' in perpetual movement with each other. From

35 For example, some interviewees related to me as 'outsider' because in the interview they would explain certain Māori customary concepts, stories and metaphors, translate Māori words and describe geographic locations in Kahungunu territory they assumed I was unfamiliar with. Yet, in other instances, I was treated more as an 'insider' because those same things were not elaborated on since the interviewee assumed I already knew them. 
beginning to end, I did not engage with the kaupapa and my interviewees as being 'only insider' or 'only outsider', nor as 'partially insider' and 'partially outsider'. Hawaiian epistemologist Aluli-Meyer states, "The world is more than dual. It is whole" (2008:225); as such, I engage(d) my 'whole being'. 


\section{Chapter Three: Identity}

"It is no longer possible... to represent the unity of identity as mere sameness, and to disregard the mediation that prevails in unity."

Martin Heidegger ${ }^{36}$

"That word universe means unity in diversity and that's what holds the whole fabric together. But this modern [iwi] construct says: 'No, no. There's only unity and the one way of doing it'... To me that's wrong."

Tamati $^{37}$

\section{Ngāti Kahungunu: Constitutions of an Iwi Identity}

Identity can be understood as a combination of elements that help identify a person in specific ways. It helps to ground, shape and orient a subject to a sense of identification and belonging. Yet, if the 'unity of identity' encompasses many fused variables of diversity engaged in processes of mediation, can definitive statements even be made about it? Can identity be 'hardened', 'congealed', 'crystallised' (Brubaker and Cooper 2000:1) and framed in the Kahungunu context? My intention is not to arrive at definitive conclusions on what Ngāti Kahungunu identity is and looks like for all Kahungunu people, at all times and in all spaces. Nor is my aim to know Ngāti Kahungunu identity per se - in fact, I cannot know it, for I do not live it. Instead, I seek to weave together the personal and poignant meanings of ancestral, place and group identity as experienced and expressed by a particular group of Kahungunu descendants in a specific time and space. Only by illuminating such perspectives might we be equipped to better reflect on how Kahungunu senses of self are constructed and practiced, generated and lived outside of designated Kahungunu domains. This chapter takes an analytic expedition into the current journeys of Kahungunu descendents and how they live and articulate their iwi identity today, in Wellington.

To understand articulations of Kahungunu identity is to first have a firm grounding in the constitutions of that identity. Accordingly, we may begin this chapter by asking, not how Kahungunu identity is experienced and expressed, but by exploring what is meant by

36 In Heidegger (1969:25).

37 This is an excerpt from my interview with Tamati, who was one of my ten interviewees. 
Kahungunu identity in the first place. What does it mean to 'be' Kahungunu ${ }^{38}$ ? What are the fundamental principles of 'being' Kahungunu which differentiate Kahungunu from others? How does a robust Kahungunu identity accommodate for internal diversity, avoiding the "dangerous comforts offered by exclusivist self-other definitions" (Clifford 2001:470)? Perhaps we may ask then, what is it to 'become' Kahungunu? And, does that process allow for the mediations of difference that transpire amongst Kahungunu groups?

The people of Ngāti Kahungunu are united through shared genealogical lines extending back to the eponymous ancestor, Kahungunu ${ }^{39}$. Yet, we may ask, what are the properties of claiming a Kahungunu identity and for belonging to this tribal society? Maaka (2003:23) notes that the two key elements which validated tribal membership for pre-colonial Māori were whakapapa and occupation of a given territory. Consequently, to 'be' Kahungunu presumed irrevocably belonging to a descent-based community defined and 'othered' by unique characteristics - those which included Kahungunu lineage and its associated territory. But, to help clarify what Kahungunu identity and belongingness mean today, we need to first uncouple 'tribe as identity' and 'tribe as organising paradigm' (Maaka and Fleras 2005:72). To do so, let us look to the past for what has become a conceptual and concrete frame to hold and represent Kahungunu identity today $-\mathrm{iwi}^{40}$.

\section{Iwi as Social Organising Paradigm}

Historically, Māori identities and groups were in a perpetual state of metamorphosis. The social groups that formed reflected the ancestors and past events (Maaka 2003:21) invoked to activate or deactivate certain relationships. Therefore, in this sense, identity

\footnotetext{
38 'Being' is used here to denote a non-temporal state, that is, a mode where one does not enact an identity in a momentary way, but simply is that identity, permanently and unconditionally, as opposed to merely 'performing' it.

39 Ngāti Kahungunu is the result of the union between Kahungunu and Rongomaiwahine. Ngāti Kahungunu literally means descendents of Kahungunu (Maaka 2003:21; Mead 1997:193). However, that is not to claim that Kahungunu iwi necessarily began in the lifetime of Kahungunu the man. Elaborations will be provided shortly from Ballara (1991) and Maaka (2003).

40 I have decided to refer to Ngāti Kahungunu primarily as an 'iwi', as opposed to a 'tribe', since iwi is specific to how Kahungunu today recognise themselves - as a broad group related by descent and who organise socially accordingly. Tribe, on the other hand, is non-specific and an ambiguous term that can describe other social formations such as hapū, whānau and non-whakapapa based Māori groups.
} 
affected social organisation; when the former morphed, the other often followed suit ${ }^{41}$. Māori social organisation naturally underwent internal changes by being absorbed into other groups through warfare, familial discord, marriage, migration and settlement (Poata-Smith 2004:173). Poata-Smith affirms that "the territorial, linguistic, cultural and political boundaries between neighbouring groups were frequently blurred" (2004:173), lacking clearly defined borders, fixed shapes and hardened, unyielding forms. Iwi were mostly conceptual communities that rarely congregated, and when called to, did so mainly for purposes of inter-tribal or inter-regional war. But, at a time lacking inter-group conflict, iwi were a dormant and ambiguous label. Maaka (2003:23) states that by the end of the $18^{\text {th }}$ century, hapū were the dominant physical forms of social organisation among Māori, being either autonomous units or subordinate to more powerful hapū (Maaka 2003: 25).

\section{i. The Kahungunu Project: Post-Contact Constructions of Ngāti Kahungunu Iwi in the $19^{\text {th }}$ Century}

Iwi as we know it today, is a "popular" (Maaka 2003:141) organised form of groupby-descent, or tribe ${ }^{42}$. However, iwi is "not a natural, primordial construct" (Poata-Smith 2004:179), but a historically-determined, politically-influenced socio-cultural production. Angela Ballara (1991) traces the construction and development of modern-day Ngāti Kahungunu iwi through testimonies delivered to the Māori Land Court in the $19^{\text {th }}$ century. In her doctoral thesis, The Origins of Ngāti Kahungunu, she describes Ngāti Kahungunu iwi as largely a reaction to and consequence of colonialism because "at no time in the contact period did the Māori population of the region from Te Māhia to Wairarapa together form an ideological whole" (1991:21). Kahungunu, as an all-encompassing identity and formulaic group, was a social inscription endogenously adopted by and exogenously imposed upon the occupants of the regions from Wairoa down to Wairarapa.

Ballara argues that Māori people in the regions from Wairoa to Wairarapa strategically named and labeled themselves. They chose to coalesce and broadly identify

41 However, this is not to imply that the reverse does not transpire, too.

42 Although 'tribe' may be considered to be a form of social organisation founded on descent, it is a very loaded term in contemporary Māori society since it can also encompass Māori assemblages based around shared ethnicity and commitment to specific locality. See the Waipareira Claim WAI 414 (Waitangi Tribunal 1998) in which the West Auckland Urban Māori Authority Waipareira argues for the status, label and rights of a tribe. 
around the Kahungunu name - since that ancestor and his descendents had the greatest mana at the time - in order to collectively oppose colonial occupation and authoritatively speak against Crown policies that threatened their self-determination. In contrast to hierarchical configurations of Māori society - known by some as the 'Best/Firth model' (Ballara 1998; Maaka 2003; van Meijl 1995) such that iwi (tribe) presides over hapū (sub-tribe) and hapū over whānau (extended family) in fixed units - Māori social groups were instead constantly being reconfigured according to circumstance and "often the hapū and iwi were one in the same" (Maaka and Fleras 2005:78-79). Ngāti Kahungunu iwi was purposefully assembled and deployed in a crisis period of external invasion and land confiscation. Colonial pressures and agendas propelled the acceleration and solidification of a conceptual Kahungunu identity and its adjacent social grouping across the Central- to South-Eastern seabed of the North Island.

Ballara claims that the post-contact period groups currently referred to as Ngāti Kahungunu, were 'named' and territorially positioned by Non-Kahungunu others, as well. She states that around the early to mid-part of the $19^{\text {th }}$ century:

"Ngāti Kahungunu had two major successful social groups using its name in Wairoa and Heretaunga. Through its genealogical links with iwi outside the region, and its military successes over some of them, it was the best known local descent group outside the region. The tendency to label all the Māori inhabitants of the region as Ngāti Kahungunu was to be reinforced by Māori practices and European bureaucracy until many Māori people identified themselves as Ngāti Kahungunu simply because they lived within its 'territory' as recognized by outsiders, Māori and Pākehā” (1991:22).

In naming the territories Ngāti Kahungunu, Māori and Pākehā effectively ascribed that label to the people, too. For Māori living North and West of the block designated as Kahungunu rohe, the people dwelling within certain parts of that block were recognised as holding the zenith of mana for the region and thus, had the greatest claim to preeminence over the entire area and all the groups within its bounds. For Pākehā (governments and ethnographic researchers), referring to the regions' occupants as Ngāti Kahungunu was arguably a simplified and strategic way of engaging with complex social systems and polities riddled with histories of continuous group inflation and deflation that 
they knew little about. Ballara notes that this form of "blanket labeling... arose partly from ignorance of non-kin genealogy and partly from a kind of convenient regional coding" (1990:15).

The Kahungunu identity mandated and summoned in reaction to colonialism, and its consequential pan-tribal process of iwi formation continues to be sustained presently as such, reflecting quite a different model from the pre-colonial era. Ballara (1991) claims that a Kahungunu identity and group based on whakapapa did exist before European arrival. However, she adds that as a conceptual and socio-political body, it stretched ideologically and developed organisationally throughout the course of the last centuryand-a-half.

\section{ii. The Kahungunu Project: Contemporary Constructions of Ngāti Kahungunu Iwi in the $20^{\text {th }}$ Century}

Maaka and Fleras (2005:74-77) situate the present unification of Ngāti Kahungunu as largely a product of the period of retribalisation. Retribalisation was a reaction to a prior period of detribalisation, characterised by the mass migration of Māori from predominantly rural tribal areas to city centres like Auckland and Wellington, mainly from the 1940's onward. Migrating Māori of that era are classified as having been 'detribalised' in the sense that the tribe was no longer the central focus of their daily lived experience $^{43}$ (Maaka 2003:iii; Maaka and Fleras 2005:72). This period of detribalisation helped develop a specifically pan-Māori culture and enhance an ethnic Māori identity as it united Māori around the country through common experiences of migration, sociocultural alienation, socio-economic impoverishment and socio-political marginalisation ${ }^{44}$. However, the transition from detribalisation to retribalisation in the 1980's re-focused

43 Implying that Māori who migrated to cities became 'detribalised' on the level of social organisation does not necessarily equate to the negation of their tribal identity. Erin Keenan (2009) suggests a reexamination of the post-World War II period of 'detribalisation' and the employment of descriptive terms such as 'urban' and 'urbanisation'. Her preliminary doctoral research shows that Māori in the Ngāti Pōneke Young Māori Club in Wellington in the middle of the $20^{\text {th }}$ century did not necessarily consider themselves to have become predominantly an 'urban people' by shifting their lives into the city, as New Zealand historiography would attest. Instead, many continuingly identified themselves as predominantly 'tribal people'. It is important to keep in mind, however, that this may be attributable to the general experiences of first generation migrants who seek to preserve and affiliate more to an identity mostly developed in the homeland they (most recently) left.

44 The period of detribalisation only assisted in developing an already existent pan-Māori identity and multi-tribal unity, largely began through Christianity and pan-tribal movements such as Ratana, Kingitanga, Te Kotahitanga, and the like. 
identity issues and development concerns from a common 'Māori experience' to a particular 'tribal experience'. Maaka $(1994,2003)$ argues that the retribalisation period of Māori society in the 1980's and 1990's encouraged the infrastructural "freezing" (Maaka 1994:314) of 'traditional' Māori social groups. Barcham (1998:305-307) adds that it further developed a government-inspired "re-Iwi-isation of Maori society" (Barcham 1998:306). This 'freezing' was aided by the combined result of multiple forces, to which the following played a part:

- The creation of the Waitangi Tribunal in 1975 and its subsequent Treaty of Waitangi Act 1985;

- The deregulation of the national economy in the 1980 's;

- Māori aspirations for greater autonomy and tribal self-governance;

- The establishment of the Iwi Rūnanga Act 1990 (Barcham 1998:306; Maaka 2003:141).

The Waitangi Tribunal provided space for claims to be lodged by Māori groups and individuals seeking justice from the Crown for acts in breach of the Treaty of Waitangi and te Tiriti o Waitangi, respectively ${ }^{45}$. Its 1985 amendment allowed the inclusion of historic claims dating back to 1840 to be filed; this Act encouraged tribes to reflect the social forms they supposedly possessed at the time of the signing of the Treaty in order to legitimise their claims ${ }^{46}$. Giselle Byrnes states that the Waitangi Tribunal has a trackrecord of compressing past and present into a single unit, believing the Treaty and its principles to be "above and beyond historical time" (2004:89). Such an attitude requires Māori to 'prove' their legitimacy to the Crown in the settlement process by showing their tribe to be atemporal, and thus, unchanging.

Maaka (2003) explains how more localised Māori 'control' coincided with the neoliberal policies of the 1980's which pushed for less government intervention in issues of national economic policy. Furthermore, Māori political agitation in the 1970's continued into the 1980's with a heightened desire for greater tribal self-determination. All of these

45 While te Tiriti o Waitangi is supposed to be a translation of the Treaty of Waitangi, there are important semantic differences between the two versions, making them distinct documents, entailing in some instances, divergent rights and obligations. See Biggs (1989) and McDowell and Webb (1998).

46 Coupled with a conditional legitimacy was the possession of a 'traditional' body that could cope with the administrative and managerial duties expected of compensation recipients from settled claims. 
culminated in the government establishing the Iwi Rūnanga Act 1990 which sought to make iwi the preferred vehicle for Māori development ${ }^{47}$ (2003:141). The Rūnanga Act effectively 'artificialised' iwi into becoming corporate bureaucracies - namely Iwi Authorities, stifling the historically malleable nature of Māori social organisation ${ }^{48}$. Although the Act was short-lived, the concept of iwi-led Māori development was embedded in government approaches with Māori (Maaka 2003:147) so that iwi development would become equated with Māori development ${ }^{49}$. Barcham confirms that "by the beginning of the 1990's the New Zealand government had reached the conclusion that only traditional kin-based Iwi were their Treaty partners" (2000:141).

Maaka states that despite the propagation of Kahungunu as one, homogenous group, they are widely perceived to be geographically divided, mainly into three regions: Kahungunu ki Wairoa (North), Kahungunu ki Heretaunga (Central), and Kahungunu ki Wairarapa (South) ${ }^{50}$ (2003:153). The establishment of Te Runanganui o Ngāti Kahungunu in the early 1980's was an attempt to formalise Kahungunu and other groups under the authority of one name, one body, and one identity (Maaka 2003:153). This caused the Kahungunu Iwi Authority to become the official voice of the tribe and of other tribal groups in designated Kahungunu rohe ${ }^{51}$. The grand vision for the Runanganui was as

47 The Iwi Rūnanga Act 1990 is but one example of long-standing Crown attempts at 'dealing' with Māori through iwi structures. For example, in the 1880's Governor Grey attempted to encourage and formalise a local and district rūnanga system through the Trust Boards Act (Ward and Hayward 1999:389). Nonetheless, the Iwi Rūnanga Act is a potent example of continued, modern-day government policies of engaging with iwi as "the focal economic and political unit" (Statistics New Zealand website, Iwi - New Zealand Standard Classification) of Māori society.

48 Maka states that an "Iwi Authority is a corporate group elected by an iwi, or a group of iwi, to deal with the government on its behalf" (1994:332). Lynette Carter (2003) argues, in her PhD thesis, that modern iwi are not the whakapapa-based structures they are understood to be where leadership is generally passed on or inherited along the senior descent-line. She says that contemporary iwi have become bureaucratised bodies whose officials are elected by tribal members. Thus, tribe in this sense, along with iwi, should not necessarily be understood as 'traditional' entities or as a straight-lined continuum of Māori socio-political structures.

49 Iwi have been used by the Crown as 'traditional' forms of Māori social units that (can) extend government authority over Māori at local, decentralised levels (Maaka 1994:316, 2003:141) and through strategies of devolution (Ngati Kahungunu Constitutional Review Committee 2000:21; Ward and Hayward 1999:394).

50 These internal, geographic distinctions are reflected in the 2006 New Zealand Census which profiles Kahungunu according to four geographic settings - the aforementioned, as well as Ngāti Kahungunu ki Te Whanganui-a-Orotu (Napier), so that one can self-identify as being of one particular area, instead of more broadly, as Kahungunu.

51 Specific groups which became absorbed and incorporated under the Kahungunu name were Rongomaiwahine of the Māhia Peninsula (who may or may not descend from Kahungunu, but in either case privilege descent from Rongomaiwahine) and Rangtitāne of Wairarapa and Dannevirke. 
Maaka puts it, "an attempt at tribal self-government" (2003:159). On the other hand, it also meant the Iwi would be formally "recognised by government and be eligible to handle public monies" (Maaka 2003:153) making it function largely as a service provider ${ }^{52}$ for its people, though still under the watchful eye, 'care' and control of the Crown (Ngati Kahungunu Constitutional Review Committee 2000:22). Maaka notes that the Runanganui surveyed and divided Kahungunu territory further with little local consultation into six taiwhenua, or autonomous districts:

- Wairoa;

- Whanganui-a-Orotu (Napier);

- Heretaunga (Hastings);

- Tamatea (Central Hawkes Bay);

- Tamaki-nui-a-rua (Dannevirke);

- Wairarapa (Maaka 2003:154-155).

Over the course of a few years, the Runanganui was overcome with a "lack of accountability and failure to deliver" (Ngati Kahungunu Constitutional Review Committee 2000:22) to the Kahungunu people. Moreover, the lines between Kahungunu iwi as social organisation and Kahungunu iwi as identity were becoming increasingly blurred, making the Authority seem for many Kahungunu as if it was the iwi incarnate (Ngati Kahungunu Constitutional Review Committee 2000:23). As a result of internal problems, the Runanganui was replaced with NKII in 1996, which is still in effect today, retaining an executive board and a similar composition of taiwhenua groups to that created by its previous incarnation ${ }^{53}$.

\section{Iwi as Identity Label}

Current interpretations of iwi in contemporary Māori society have brewed the parallel idea of a primordial, ever-present identity. As the detribalisation period of Māori society advanced a Māori cultural renaissance (Webster: 1998:28), the retribalisation period was correlated with an iwi cultural renaissance. The notion of iwitanga, or 'iwiness',

52 Part of the project for Kahungunu unification was also to make the administration and distribution of education and health services to Māori across Kahungunu rohe more manageable and under visibly Māori control.

53 Throughout this thesis, 'Iwi' (capitalised) will be used interchangeably with 'NKII'. 
strengthened in this period as its signifier iwi became a widely recognised and accepted representation of 'traditional' Māori society ${ }^{54}$. Propelling the notion of iwitanga is tribal awareness, knowledge and pride, and the assertion of historic tribal difference within Māoridom, making a Māori identity seem peripheral to one's tribal 'true-self'. During the Fisheries Claims in the 1990's, prominent Māori leaders proclaimed iwi (or hapū) as the focal point of their cultural identity over a more pan-Māori label in a national attempt to identify the rightful bearers of the country's fishing quota. Prominent Māori leaders, such as Ngāi Tahu's Sir Tipene O'Regan, espoused an identity centred on the tribe and moreover, invalidated the experiences of being a non-iwi Māori: “'I regard myself as Ngāi Tahu...the thing that makes me uniquely of this place - is my Ngai Tahu descent. I'm not interested in that being a part of a general Māori descent in particular"' (cited in O'Regan 2001:55). For some, to accept non-iwi Māori as the rightful inheritors of Treaty rights and settlements was to challenge the definitions and understandings of contested concepts such as 'Māori', 'iwi' and 'tribe' ${ }^{55}$. According to Tipene O'Regan's discourse, to be authentically Māori is really to 'be tribal', and to 'be tribal' equates to being cognisant of one's whakapapa, as well as being intra/inter-tribally recognised as a member of an iwi/hapū; for him, identity necessitates being quantifiably measured. In addition to being a 'return to tradition', iwi pride became a form of resistance to being homogenised and ethnicised as Māori. For example, John Rangihau privileges his Tūhoetanga over Māoritanga, claiming the primacy of his tribal identity (Meredith 1998:9-10). However, the same voices proclaiming an organic form of iwi subjectivity did in fact 'turn to the past' to justify their use of iwi/hapu in a fixed and permanent way, displaying what Maaka calls, the dominance of the Best/Firth model as a "deeply-entrenched stereotype" (2003:201), even amongst some Māori.

Māoritanga today is largely measured by a given set of conventional indicators, which include: self-identification, whakapapa, marae participation, whānau associations, ties to ancestral land, involvement in te ao Māori, contact with Māori people, institutions and

54 In extreme cases, iwitanga is relegated to a form of tribal fundamentalism, where strict criteria is outlined for not only belonging, but even claiming an identity as an iwi-Māori; meaning that selfidentification is no longer a substantial enough qualifier. John Tamihere is famous for vocalising antifundamentalist sentiments and for politicising the politics of exclusion that such an ideology can purport (Butcher 2003:44-45).

55 See the Treaty of Waitangi (Fisheries Claims) Settlement Act 1992. 
networks, and competence in te reo Māori (Durie 2003:69; Stevenson 2004:37). However, problems arise in securing a positive sense of Māori-self and inclusion in the Māori world for those who may lack the aforementioned 'tenets' of what has become a dogmatic form of Māori identity ${ }^{56}$. Moreover, for those Māori who are aware of their whakapapa and tribal connections (i.e. iwi-Māori), there is even greater expectancy to meet and 'perform' those qualifying attributes, including those peculiar to their particular tribes. Often, if they do not meet those cultural expectations they are seen by tribal members as less 'authentic' and according to Hana O'Regan (2001:101), thought to be unworthy of full tribal participation.

Meredith (2000) warns against exercising Māoritanga as a kind of permanent essentialism that at the very least dehistoricises and naturalises the Māori subject, and at its worst, leads to the exclusion of those who do not display 'authentic' Māori behavior and traits. Although Meredith does not argue this in light of iwitanga, we should nonetheless be careful not to solely view iwitanga as a totalising ontological essentialism filled with strict and limited participatory criteria, that if not met, excludes kin members who may otherwise wish to participate in the tribe. The exclusion of kin members can invalidate unconventional experiences and alternative expressions of tribal identity that can serve as examples of tribal continuity. Borell (2005) petitions for the exigency of investigations that seek to locate peripheral expressions of Māori identity that may challenge, complement and expand orthodox understandings of 'being Māori'. However, in investigations of Māori society, group particularities must not get completely overlooked and absorbed by the generalities made on behalf of Māori (Guerin et al. 2006; Irwin 1992). In fact, as the tribe remains at the heart of Māori identity (Maaka 1994:314, 2003:iv; Maaka and Fleras 2005:68), studies in Māori society could benefit from considering tribal dimensions, in order to fill deficiencies in understandings of identity and belonging. And so, I extend Borell's petition into the tribal domain of iwi.

As Māoritanga is about being and enacting "the Māori way" (Meredith 2000:10), iwitanga is concerned with 'the iwi way' ${ }^{57}$, as there are different cultural properties, histories, protocol, dialects and customary practices that stylise iwi groups, distinguishing

56 Examples of such alienation and exclusion are with urban rangatahi Māori (Borell 2005; van Meijl 2006) and those classified as non-iwi or predominantly ethnic-Māori (McIntosh 2005).

57 A similar understanding can be applied to hapūtanga, maraetanga and so forth. 
them from one another. Therefore, if iwitanga is about 'the iwi way', then, Kahungunutanga naturally is concerned with 'the Kahungunu way', the cultural identity of Kahungunu people and how they are essentially, Kahungunu. However, in the same way that Ihimaera (1998:16) says of Māori, Kahungunu are not today what their ancestors were yesterday, nor will their descendents of tomorrow be what they are presently. Similarly, as Jacq Carter (1998:259) suggests of Māori identity, we can consider how there is no uniform Kahungunu reality, nor one kind of Kahungunu identity, especially since Kahungunu are not replicas of each other. They are individuals who articulate their identities in diverse, unique and specific ways. How, then, does one determine the characteristics of the 'Kahungunu personality'- especially for a people composed of layered, internal (group) difference - and who determines the composites of that personality? Can there really be a 'Kahungunu way' in the midst of layers of difference and splintering? And, can it avert the opposite type of extremism, in what Borell (2005), Meredith (2000) and Tamihere (Butcher 2003) caution us against: an ontological fundamentalism that leads to the politics of exclusion and marginalisation? Has the movement of Kahungunu people outside of their tribal grounds to Wellington spawned identity articulations and social groupings that can possibly challenge the project or contradict the notion of a unified Kahungunu whole ${ }^{58}$ ? Kahungunutanga as expressed by my interviewees, provides a conceptual language, while Diaspora theory is engaged with as a theoretical frame, to directly address these questions, as well as those of 'be(com)ingness' proposed earlier in this chapter.

\section{Theoretical Framework}

\section{i. Diaspora: Roots - Routes}

"Even though I live here [in Wellington], I choose to live here and I choose to remove myself from Kahungunu. But, within me I am still Kahungunu, and wherever I go in the world - when I was living overseas... the same thing

58 The Kahungunu rangatira of the 1800's Ihaka Whaanga coined the term, Te Kupenga a Te Huki, or Te Huki's Net. The Kahungunu ancestor, Te Huki "settled his children throughout Ngāti Kahungunu to keep peace and unity among the people by marrying them into influential families" (Simpson et al. 2003:37). Te Huki's Net symbolises and describes the connections of all Kahungunu-derived people throughout its territory since that time. It remains a powerful and often evoked metaphor of Kahungunu unity. 
happened: even though I removed myself physically from the environment, I haven't really - I've just taken time out. And it will never leave me."

Diaspora comes from the Greek word diasperio meaning dispersion, and is a broad term employed to name and describe the experiences of departure by national, ethnic and religious collectivities from an original homeland or reference territory to a foreign, 'new' land. The diasporic person can be one who dwells in a space of tension produced by binary juxtapositions of what is definitively: the there and the here, the old and the new, the true and the superficial, the constant and the changing. This contentious space produces power relations that position the diasporic person in either side of: inclusion or exclusion, us or them (Sardar and Van Loon 2004:134). For some, it can even imply '1(o)osing' (Teaiwa 2001) stringent classifications and the questioning of identity itself, especially for those who may feel 'caught in-the-middle'. Diaspora lends itself to both the preservation and the transformation of a people, and to their (dis)continuities across time and space.

Modernist approaches to studies on diaspora invoke 'classic' cases, many times summoning and referencing expatriate Jewish experiences to differentiate 'real' from 'false' diasporas ${ }^{60}$ (Dufoix 2008:22). Although differentiating 'real' diasporas from 'fake' ones is the intention of many research projects, my aim is not to determine the legitimacy of using Diaspora theory in the case of Wellington-dwelling Kahungunu ${ }^{61}$. Diasporic experiences are not replications of each other and perhaps can provide little to no substantial value for the communities concerned by gauging them against each other ${ }^{62}$. Instead, much value can arise from refocusing the study of differences between diasporas to the differences within them.

\footnotetext{
$59 \quad$ AT was one of my interviewees.

60 The Jewish experience of forced exile from Jerusalem nearly two millennia ago and their global scattering and pursuit to return thereafter, has served as an archetype of the diasporic experience.

61 It is not an experience to be filtered and unavoidably (in)validated by measuring it against what has previously been determined to be the 'ideal' kind of diaspora, since it is merely $a$ version.

62 Authentication exercises contribute to solidifying and upholding the bounds of binary oppositions that which is, true/false, inside/outside. Whereas, my intention is to problematise the rigid separation of these categorisations, for they disavow the agency of Kahungunu to determine when and where such states are useful in their own lived experiences. Indeed my intention is to delve into the inbetween states, the grey areas and the border-lands as well; to document a diverse range of experiences with diaspora.
} 
Hall (1995) differentiates between what he calls 'closed' diasporas from 'open' diasporas. The former refers to linear movement of people and cultures from site A to site $\mathrm{B}$, or $\mathrm{C}$ and so forth, so that the diasporic person who resides anywhere outside site $\mathrm{A}$ does so unwillingly, with a longing and watchful eye always on the original point of departure. Such a person is characterised as possessing a deep desire to 'go back' to what is believed to be the first site of one's culture, the core of one's identity (1995:206). An essential feature of the 'closed' diasporic is a fundamental link to a place of origin that is referenced by a perpetual state of '(in)completeness' (Dufoix 2008: 34). Hall (1995) explains how the 'closed' diasporic person is essentially a preserver and is expected to maintain the 'purity' of the root culture in order to lessen the impact of physical distance and psychological separation. The maintenance of a 'pure' cultural identity is paired with the overwhelming aspiration, and indeed responsibility, to return to that sacred homeland, that place which affirms and secures (the group) identity (Hall 1990:235). In this light, the diasporic person is seen to suffer through a sense of loss derived from detachment, dislocation and in some instances, an inability to go home.

Where 'closed' diasporas travel in a straight line, 'open' diasporas traverse space circularly (Hall 1995:207). Those whose lives are reminiscent of an 'open' diaspora do not seek to return to their homeland, per se. In fact, for many, they cannot return simply because history has made them anew elsewhere ${ }^{63}$. An 'open' diasporic space is a noncentre constituted of hybrids who belong to:

"more than one world, speak more than one language (literally and metaphorically), inhabit more than one identity, have more than one home; who have learned to negotiate and translate between cultures, and who, because they are irrevocably the product of several interlocking histories and cultures, have learned to live with, and indeed to speak from, difference" (Hall 1995:206; emphasis in original).

Such a people do not emphasise an identity based upon a specific, untainted origin but focus instead upon "new ways of 'being someone"' (Hall 1995:207). The space of 'open' diaspora houses cultures 'on the move', producing identities that are the consequence of a

63 The Afro-Caribbean (Hall 1990) and the black-Atlantic person (Gilroy 1993) are the archetypical figures of the 'open' diasporic. They are a people who have been remade and who remake themselves in the new locale, drawing upon more than one "cultural repertoire" (Hall 1995:206). 
series of overlapping routes that are fluid, uncertain, at times paradoxical, and with no definitive grounding to only one particular root or place.

While an 'open', postmodernist interpretation of diaspora may be attractive, it can also be of a limiting nature since it invokes a kind of hybridity, taking refuge in a single paradigm of non-permanency and eternal change. Hybridity discourse is a reaction - be it an allergic one - to essentialist notions of the fixed, always-and-forever present "Being of beings" (Heidegger 1969:26). Not only is hybridity discourse a reaction to essentialism, it is its consequence and its versed extension. As hybridity challenges 'untainted' culture, it also presumes the existence of initial forms which are pure and have merely undergone a union with other assumed purities. Gilroy attests: "The idea of hybridity, of intermixture, presupposes two anterior purities...I think there isn't any purity; there isn't any anterior purity...Cultural production is not like mixing cocktails" (1994:54-55). According to Gilroy, the discourse of hybridity, like essentialism, internalises a prior and concurrent position that one can hypothetically 'return to'. It ignores the fact that 'purity' is implicitly a non-presence; a socially constructed fabrication. At the same time, understanding identity as being "constantly changing and fluid can breed its own limitations through establishing a new orthodoxy that cannot accommodate the strength of feeling about belonging and about the pivotal moments in the routes of identity" (Woodward 2002:160; my emphasis).

In being cautious with purist invocations, we should not assume that essentialism plays no pivotal and real role in the lives of people; we should be just as critical and clear with what we mean when employing hybridity as discourse as we are with essentialism. Spivak (1999:281) calls for deploying essentialist notions in a 'strategic' manner, meaning that before one prematurely dismisses essentialism all-together, one should clarify what necessitates its application and its itinerary of use (Fuss 1989:20). Nonetheless, Mendoza (2002) believes that essentialism ought not to be solely a 'strategic' manoeuvre. She refers to Spivak's take on strategic essentialism as an "implicitly secularizing ontological vision", saying that it makes "“mere strategies' out of deeply-held cultural beliefs and values, many of them deemed sacred" (2002:32). In the Māori world, ancestral roots and their conjoined spiritual connections redeem essentialist deployments. 
Māori kinship connections coupled with spiritual bonds to people and to place(s) can indeed transcend time and space to become purposeful and sophisticated articulations of essentialism. For example, Māori social and customary practices informed by and activated through the tangata whenua-manuhiri relationship regulate the mana of both groups through complicit behaviours within set categories that go largely unchallenged ${ }^{64}$. As well, there are connections to spirit that people believe in whole-heartedly that do little good by being debunked and devalued, causing to 'de-sacralise and de-mystify a world emptied of its spiritual wonder' (Mendoza 2002:32). All in all, notions of hybridity in 'open' diasporic discourse generally de-emphasise the relevance of 'being' and belongingness predicated on 'roots', understanding them to be "bad essentialisms" (Clifford 2007:200).

\section{Indigenising Diaspora}

Many Diaspora theorists tend to dichotomise rooted essentialism with routed hybridity. Clifford identifies a "dialectical instability" (2007:201) in such a discourse as separatist intentions attempt to make 'closed' diasporas and 'open' diasporas mutually exclusive. In the lives of Indigenous peoples, this can work to unnecessarily 'fix' them to either being 'rooted' or 'routed'. However, the Indigenous experience for some may typify a necessary employment of both 'roots' and 'routes'. To say that an Indigenous person who dwells in a state of diaspora is perpetually only a transformer - an agent of re-routing, with no stable grounding - or only a preserver, victimised through a process of uprooting and focused upon 'the great return', is to simplify quite complex processes that overlap, as well as dynamic relationships to identity, place and community. For example, as AT's earlier quote suggests, though she may dwell at a distance from her home in Kahungunu, that does not mean that Kahungunu exists only outside of her; she may not choose to go where her roots are, yet they inevitably are (with) her and so go with her wherever she may be. AT's relationship to her identity as Kahungunu, like that

64 This is not to imply that the tangata whenua-manuhiri equation cannot be flexible and fluid, especially since there are many who are both tangata whenua and manuhiri in a single area. The activation of whichever status is dependent upon context, choice and one's consciousness of such roles and of their meanings. See Chapter Four for further explanations. 
of many Indigenous peoples resisting being written-off into history, is as a centre 'on the move'.

\section{i. Indigenous and Diaspora}

Popular understandings of diaspora take for granted the internal migrations of people and groups within the territorial domains of the nation-state. The International Organization for Migration (IOM) defines migration as "the process of moving, either across an international border or within a State. It is a population movement, encompassing any kind of movement of people, whatever its length, composition and causes" (Trujano 2008:15). For many Indigenous peoples today - specifically those victim to Anglophone (neo)colonialism - leaving their traditional territories, their homelands, to make and lead lives elsewhere means for many, a shift to the urban milieu.

In countries such as Canada, the United States, Australia or Aotearoa/New Zealand, the movement of Indigenous populations to cities can mean just as much geographic distance, cultural foreignness and social tension as experiences of international migration. In a report for the IOM, Trujano explains the phenomenon of contemporary Indigenous movement and describes internal rural-urban migration as a contending reality and pressing issue:

"Many indigenous communities have started to migrate to cities in their countries of origin in the hope of economic development in urban centres. However, this move can prove extremely difficult for indigenous communities who have to adapt their cultural practices, lifestyles, and economic expectations to fit in with their new urban locations" (Trujano 2008:24).

In The Urban Indian Experience in America (29), Fixico describes three dominant stereotypes of the 'urban Indian' in the city:

- A recent migrant who brings his traditional culture with him into the city (very much in the form of the 'closed' diasporic);

- Those who are linearly transitioning out of their tribal root culture into the newly routed city culture through 'transculturation' and,

- One who has become an urbanite, an assimilated by-product of the urban mainstream. 
The aforementioned perceptions of the Indigenous migrant to the city (Trujano 2008) and of the 'urban Indian' in America (Fixico 2000) portray equally limited and incomplete understandings of the multifaceted nature of Indigenous lives and cultures by representing the Indigenous person as a one-dimensional figure of either/or ${ }^{65}$. For instance, the broad assumptions made that Indigenous peoples migrate to the city in a one-off, one-way move from rural to urban denies the multi-sited interactions they have to community and to place(s) ${ }^{66}$. Woodward affirms, "The interpretation of migration as motivated by either push or pull factors can underplay the different experiences among migratory peoples and over-emphasize the homogeneity of any group of people who are leaving their home to settle in another place" (2002:52). As well, describing Indigenous people moving to cities as largely one in search of employment ignores the plethora of reasons as to why they are there ${ }^{67}$. Moreover, the stereotypical representations of Native Americans living off-reservation do not speak to the fact that many are agents in choosing what kind of cultural identity to deploy and when in their life to do so.

Morgan (2006) and Clifford (2007) urge a closer exploration of diasporic dimensions in contemporary Indigenous lives as they believe them to be, in many ways, articulated continuations of group survival. In Unsettled Places: Aboriginal People and Urbanisation in New South Wales, Morgan speaks of the contemporary forms of Aboriginality in Australia, which are based upon cultural adaptations just as much as they are on continuities. He argues that Aboriginal cultures are, and always have been, living expressions of a dynamic identity. Aboriginal cultures do not survive "in a state of petrified tradition, notwithstanding the reverence that may exist for that tradition"

65 When speaking about Indigenous peoples in the city, it is important to be cautious and critical of discourses that try to binarily juxtapose 'Indigenous' or 'tribal' with 'urban', assuming that the latter negates the others. To live in a (sub)urban or city space as Indigenous is not a 'disarticulation' (Teaiwa 2010) of one's claim on indigeneity or a loss of authenticity, but can be an articulation of what Gilroy calls "the changing same" (1993:xi).

66 Approaches to the multiple ways of belonging to place and to community for Indigenous peoples beyond simply city, regional or national identifications - are needed. Some Indigenous peoples possess alternative ways of understanding, determining, naming and relating to space that are not always, nor largely congruent with or recognised by the nation-state. Borders between tribal groups exist as a separate layer to that of internal state boundaries, playing a significant part in how the Indigenous person navigates his/her world and creates and maintains relationships to space(s) and place(s). This will be elaborated on in Chapter Four.

67 Reasons may include: government policies, forced removal, following extended kin relations, pursuing a certain education, seeking a personal change, or a lifestyle preference. 
(Morgan 2006:141). They survive through processes of "negotiation between the old and the new" (Morgan 2006:142). Without assuming the old ways lacked dynamism and change, modern-day Indigenous peoples are and always have been "improvising new ways to be native" (Clifford 2007:198). Indigenous cultures are as they have always been: living, regardless of what the point of expression is or where the site of departure may be. Morgan affirms:

"Most Indigenous cultural production no longer takes place on traditional country but at alternative sites - at sporting carnivals, music and dance performances, on the premises of community organizations, in pubs and clubs. These are very different from the trite and romantic presentations of Aboriginality" (2006:153).

To adapt Clifford's phrase, the Kahungunu diasporic is more like an offshoot in a tree than a broken branch (Clifford 2007:213). Attempts at indigenising diaspora can allow us to speak about Kahungunu routes without losing, disregarding or diminishing the relevance and place of Kahungunu roots; and vice-versa.

\section{ii. Māori and Diaspora}

Māori oratory traditions conjure memories of ancestral people, events and places which narrate ancient travels and dispersions from and around the Pacific to Aotearoa/New Zealand. One such place is seen as the spiritual homeland of Māori: Hawaiki. The proverb, "He kakano ahau i ruia i Rangiatea", meaning, 'I am a seed dispersed from Rangiatea ${ }^{68}$, , is a conceptualisation by Māori that lends "credence and mana" (Winitana 2008: 4) to the language of diaspora. Tales of journeying matched with multiple sites of belonging are intimately part of Māori history and reflect an integral aspect to the endurance of its peoplehood. Moreover, it spatially bridges gods, ancestors and living people together in an unyielding continuity (Walker 1989:36). Clifford points out that the historical landscape of ruptures and affiliations reveal that survival and dynamism are part of Indigenous realities (2007:201). This can be true of Māori in general and of Kahungunu in particular. NKII attests that although the Kahungunu people have been dispersed outside of their traditional abodes as a result of Crown policies, their "adaptability and will to survive" (Ngati Kahungunu Constitutional Review Committee

68 This proverb and translation were extracted from Winitana (2008:4). For Māori, Rangiatea is part of the ancient place of Hawaiki. 
2000:68) have not been compromised. There is nothing fundamentally new about Māori relocating their lives outside of tribal territories and expanding their scales of interaction and their networks of affiliation, especially since they are largely following patterns that stretch back to ancient times. Māori history is one that recognises migration and processes of cultural preservation and transformation.

Although Māori have been migrating outside of Aotearoa for at least two centuries, scholars and researchers have recently employed Diaspora theory to situate and explain Māori mobility and external migration, mainly to Australia (Bedford et al. 2004; Hamer 2007; Winitana 2008). An emerging Māori disapora is reported to be occurring as a consequence of increasing Māori settlement in Australia, as it has been heightened most notably in recent decades with an estimated one in seven Māori now living in Australia ${ }^{69}$ (Hammer 2007: xii). Te Puni Kōkiri (TPK), or the Ministry for Māori Development, commissioned Paul Hammer (2007) to conduct a comprehensive study of Māori residing in Australia. The report seeks to outline the economic and cultural relationship between Māori at home in New Zealand and abroad in Australia, proving that "Māori have become a transnational people" (Hamer 2007: xi). It assumes that transnationalism and diaspora are new phenomena that Māori must now contend with, disregarding the experiences and consequences of their historically domestic tribal border-crossing. Māori experiences of mobility, migration, and diaspora are nothing new; Australia is merely just another point in their expansive network of spatial connections and attachments.

\section{Māori Diaspora in Aotearoa/New Zealand}

Diaspora in the contemporary Māori context can be said to have begun with domestic translocal shifts, and not necessarily through global transnational movement. If iwi-tribes are positioned as kin-nations, with a distinct history, determined territory, particular dialect and customs, then Māori have been 'border-crossers' for centuries. However, little academic attention has been given to internal Māori migration and its effects upon one's tribal identity and heritage. The few studies on contemporary internal Māori migration

69 'Mozzie' is a social label used colloquially to identify Māori immigrants to Australia and Australianborn Māori from those born in and/or living in New Zealand (Sullivan 2008). 'Mozzie' is gestating into a contending social reality that extends questions of Māori identity, cultural survival and development beyond Aotearoa's shores, and into Australia. 
(Bedford et al. 2005; Sin and Stillman 2005) lend themselves to similar deficiencies exhibited by some international surveys on Māori diaspora; those which generalise Māori or take for granted the tribal formula in the identity equation.

The Māori and Psychology Research Unit at the University of Waikato has conducted ongoing longitudinal studies documenting the effects of Tūhoe inter-rohe mobility in recent years, more specifically to the Waikato region (Nikora et al. 2004; Guerin et al. 2006). The studies investigate the social consequences of Tūhoe movement and/or settlement to Hamilton, by focusing upon lifestyle transitions for 40 recent 'movers' and

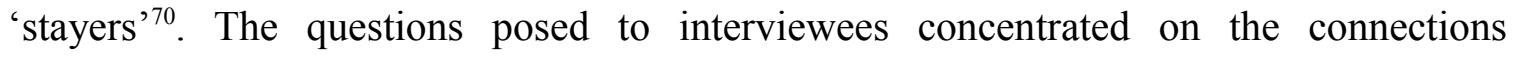
maintained with Tūhoe-home and the bonds formed with fellow Tūhoe in the Waikato, attempting to retain and strengthen their Tūhoetanga. The results reported by the studies show that as a consequence of living away from home, Tūhoe identity was intensified in the lives of the interviewees. However true, the conclusions of the study could also reflect the types of questions posed, which seemed to focus more upon how Tūheotanga is maintained, weakened or strengthened - in other words, how it is preserved in the Waikato - as opposed to how it may be challenged, influenced by other factors and potentially transformed. Nevertheless, interest in iwi mobility and internal migration is gestating and proves that Māori journeying and senses of home outside of tribal districts today are not unique to Kahungunu.

\section{i. Kahungunu in Wellington}

In relation to tribally-determined places, there are what Clifford implies are indigenous types of diasporas (2007:200). In the Kahungunu experience, diaspora cannot be viewed as only a movement to the urban space of Wellington and the country's capitalcity; it includes movement outside of Kahungunu rohe and into the lands of Te Ati Awa, Ngāti Toa and Ngāti Raukawa. The tension produced by the Kahungunu presence in the city is not only a question of Indigenous identity in a cosmopolitan context, but of a specific kind of tribal identity within the lands of other, local tribes. I prefer to stress this point of multiple relations to space as my focus is not necessarily just on Kahungunu

70 The study relies on a five-year gauge designated by Statistics New Zealand to differentiate between inter-regional Tūhoe 'movers' from Tūhoe 'stayers'; the former being those who lived in a region outside of Waikato five years prior to the study, while the latter includes those who have lived in the Waikato for five to ten years, at least. 
migration and diaspora to urban areas (as this may overlook the fact that there are urban areas within Kahungunu territory as well). The focus of my research is more upon Kahungunu understandings of and relations to space. And so, inter-rohe movement as opposed to just rural-urban migration is of importance in discussions on Māori-type of diasporas $^{71}$. Consequently, it makes sense to position Kahungunu in Wellington as migrants of a tribal diaspora in the territories of local non-Kahungunu Māori tribes ${ }^{72}$.

In the beginning of the $20^{\text {th }}$ century, Kahungunu were among the first Māori to migrate post-Treaty to Wellington city. During this era, some Kahungunu people were influential in forming the pan-tribal organisation, Ngāti Pōneke Young Māori Club. In The Silent Migration: Ngāti Pōneke Young Māori Club 1937 - 1948, Pirihira Heketa of Ngāti Kahungunu ki Heretaunga and her daughter Miriama Heketa are mentioned as prominent leaders in Māori performance at the club. Although Pirihia was a maternal figure to many Māori there, her identity as Kahungunu was never subsumed by her multitribal interactions, the pan-Māori identity of the organisation, nor by her life in Wellington. Eric Ramsden reported that she always felt Kahungunu at heart, exemplifying that tribal differences were still existent within the group (Grace et al. 2001:109). As Pirihia Heketa was probably of the first generation of Māori migrants to Wellington post-Treaty, perhaps many of them identified and maintained loyalty mainly to the tribe from whence they came. However, today, the relationship many Kahungunu have with their heritage and with Wellington is slightly more complicated as it involves a mix of Kahungunu people with increasingly diverse experiences:

1) Some who are first, second, third or fourth generation to Wellington;

2) Some who were born and/or raised in the Wellington region, and others who were born and raised neither in Kahungunu rohe nor in Wellington;

\footnotetext{
71 I further elaborate on how Kahungunu 'read' and relate to space in Chapter Four.

72 It is important to mention that some Kahungunu-related groups had mana over the Wellington area (Wellington harbour, Hutt Valley and Porirua) for many generations, up until 1835 - less than five years prior to the signing of the Treaty of Waitangi. In the early $19^{\text {th }}$ century, these Kahungunu groups were expelled by the current local groups, and many (then called Ngāti Ira) journeyed (back) to reside in Wairarapa (Ballara 1990; Best 1919; McEwen 1972). See Ballara (1990) for an explanation of the events that led to negotiations between Te Ati Awa and Ngāti Kahungunu groups to clearly demarcate territorial bounds that stay true today.
} 
3) Some who are self-described locals and some who are migrants and temporary visitors; and yet, some Kahungunu are both or neither.

Thus, the reality is that different lives breed different journeys, each being important in the collective biography of Kahungunu.

\section{ii. "My identity is my family and my home and where I belong"73}

A life-focused interview with Piri Sciascia, a well-known exponent of Kahungunutanga, acts as an anecdotal supplement to disclosing the properties of 'Kahungununess'. For Piri, the Kahungunu life involves the presence of family, the presence of home and the presence of community, and understanding them as being deeply connected, inter-woven and existing in relation to each other. In this way, Kahungunutanga can be said to be composed of a triad of elements, all dependent on each other: whakapapa, tūrangawaewae and whanaungatanga ${ }^{74}$. However, because Piri is a resident of Wellington and has been so for nearly 30 years, it may seem apparent that home is the obvious factor missing in his identity equation. However, he stated in introducing himself:

"Although I've lived more time out of Pōrangahau in my life, that's home and it's a home I've never left."

Like his whakapapa, home is carried within Piri wherever he is and in whatever he does; it is an intrinsic part of his identity and how he relates to and interacts with the world around him. Although it is a specific place, it is a place he visits literally, as well as emotionally and imaginatively:

"I'm not like a lot of Kahungunu-Māoris [sic] here in Wellington. A lot of Kahungunu-Māori will come here and hardly ever go home. I'm just the opposite... I've been away from home for 50 years, but I've never left home... I go home all the time... My kids go home. My grandkids go home. That's their home. So we live here in Wellington, but home is Pōrangahau."

Piri

73 This quote is from my interview with Piri Sciascia.

74 All of these elements (and some more than others) will be further explained in Chapter Four.

75 Questions posed to the interviewees are provided where relevant; otherwise, they could just be distracting or lead to confusion. 
The fact that Piri resides in Wellington does not deter him or his family from connecting and belonging to Pōrangahau in proactive ways. For Piri, physically travelling there is about nurturing identity and cultivating connections for himself, for his descendents and for the people resident in Pōrangahau.

Kahungunutanga is not only about connections to whānau and whenua for Piri, but to the iwi community as well. Being part of Kahungunu iwi is about making an effort to serve the people by showing one's face:

"We have a good time when we're home because we're just part of home - it has to do with roles, with belonging, with contribution, things that you do for your home."

Going home for the Sciascia whānau comes with responsibility. In Māori custom, the concept of reciprocity is relevant for expressing ideas of connectivity and for balancing relations. Piri and the whānau take the three-hour journey from Porirua to Pōrangahau frequently, not only for activities concerning the immediate family necessarily, but also for tāngi, birthdays and anniversaries of extended kin and friends, as well as for tribal meetings and cultural events. He articulates the constitutions of his Kahungunu identity by how he lives his life; Piri's identity is not only the presence of family, of home and of community, but also his presence with family, at home and in community.

\section{iii. Kahungunu Identity in Wellington}

How Piri positions and emphasises domiciliary location in his life is important. $\mathrm{He}$ believes his Kahungunutanga to be impervious to dwelling in and carrying-out his life in Wellington, especially since he retains measurably visible links with where he posits his vitality - in the community, land and culture of Pōrangahau. Piri chooses to adopt Wellington as a temporary abode. Yet, because his descendents make their life in Wellington as well, the chance that Piri will indeed return home to live in Pōrangahau permanently is perhaps unlikely.

The fact that none of my informants live on Kahungunu rohe suggests that they may not be fulfilling an important marker of their identity as Kahungunu. However, some of them re-articulate notions of iwitanga that claim one must reside in the tribal area or at least visit it frequently. Tamati stated in a different interview: 
"I think that Māoridom - and Kahungunu is a good example of this - we're at this juxtaposition. We're at this real crossroads because if you look at it... there's about 525,000 Māori in New Zealand, but the vast majority of those Māori do not reside within their traditional tribal bounds. They live in places like Auckland, Wellington, Christchurch, you know, the big centres where employment is... So over time you have to ask yourself: what does this mean for our culture? ... What does this mean for me and my iwitanga, my tribalism or my hapūtanga? ... The traditionalists would say that if you don't reside within your tribal bounds then you're [not authentic]... but that goes against the basic concept of our culture, that genealogy is inalienable. It doesn't matter where I live or what I do, I still have whakapapa that says, here's my tīpuna."

Tamati

Tamati's assessment of what can be considered a domestic Māori diaspora is telling, demonstrating continuing relevance in contemporary Māori society. Although many Māori have been experiencing several generations of movement and settlement outside of their tribal grounds, the same questions of identity, culture and belonging continue to circulate, which may suggest that they have yet to be adequately or fully dealt with.

The experiences of my interviewees living in Wellington suggest the extension and expansion of Kahungunu identity and culture - its definitions and meanings. Their journeys with their Kahungunutanga are just as much about 'being' Kahungunu as they are about 'not being' Kahungunu as they are about 'becoming' Kahungunu. Because of the (connected) layers of difference existent in the Kahungunu world, articulations of Kahungunutanga naturally vary from person to person.

\section{On 'Being' Kahungunu in Wellington}

\section{i. Articulations of Kahungunutanga}

Articulating Kahungunutanga in Wellington affirms ancestral knowledge and cultural pride in an identity with which one may be soundly familiar. Kahungunu consciousness is not necessarily dependent upon directly living on tribal grounds and being surrounded by staples of the Kahungunu environment, per se. A Kahungunu-centric identity was 
articulated by my interviewees raised in a strongly Kahungunu household, where emphasis was placed on 'being' Kahungunu at home, in Wellington. Te Hiwi explained:

"I think it's because of the strong influences that my mother and my grandmother give me, both being from Kahungunu - very proud of it. I think that's [the] reason why I'm so [into] Kahungunutanga... I'm not really well equipped or well knowledgeable with my other three iwis [sic]... '[C]ause I know my Kahungunu side inside and out... I'm so Kahungunu, Kahungunu, Kahungunu!"

Te Hiwi

In Te Hiwi's case, he spent most of his adolescence in Wainuiomata in Wellington, but his Kahungunu whānau played a pivotal role, nonetheless, in developing his sense of Kahungunutanga. His articulation of Kahungunutanga is a kind that is due to the sociocultural conditions in which he was raised, and suggests that living in Wellington does not necessarily impede on inter-generational extensions of Kahungunu identity.

For those who were born and brought up in the Kahungunu cultural world on Kahungunu rohe and later moved to Wellington in adulthood, Kahungunutanga takes centre stage in their identity as Māori and is transplanted with them as they move across different places. For instance, some interviewees spoke of referring to themselves as primarily Kahungunu, as opposed to Māori. This was done partly so as to be particularised according to their whakapapa and not be wholly swallowed by a non-tribal identity or completely blended into a cosmopolitan space. For example:

[Interviewer: How do you think living in Wellington has influenced and affected your iwitanga?]

"It's made me more determined because I don't want to lose my identity in this sea of diversity that is... more than my culture."

Tamati

Tamati and others who were raised in social, environmental and customary Kahungunu contexts, continue to transfer the importance of 'being' Kahungunu into their life in Wellington, interrupting solely being seen as 'just another Māori in the city'. Cellia also stated:

"For me, being Kahungunu is being me. I am Kahungunu... I call myself Kahungunu before I identify as Māori... I'm the Kahungunu-Māori, not just the 
Māori... you don't want to go too deep with someone who maybe doesn't selfidentify as an iwi but they say, 'Oh, I'm a Maori' or Māori... you don't get into it because they won't get it because they're not at that level of self-awareness as perhaps I am.”

Cellia

Cellia and other Kahungunu-Māori centre their identity on the tribe, making them fundamentally Kahungunu ${ }^{76}$. In identifying herself as Kahungunu-Māori, the hyphenation serves not only to distinguish Cellia according to her iwi; it also de-emphasises her being Māori. Her relationship to her cultural identities is hierarchically arranged, such that Kahungunu reigns supreme. Cellia's verbal articulation of the importance of her iwitanga is about pride in who she feels she really is and where she is from. But, perhaps it is also a political maneuver that articulates her sense of indigenity in specific ways.

Articulating Kahungunu identity in Wellington can be a politicising act, regardless of whether or not one grew up or lived in Kahungunu rohe. Jorgette's experience attests:

“It's funny, my Christchurch friends wouldn't specify themselves to a particular iwi. But my Wellington friends do... they're Tūhoe, they're Ngāti Pōrou, they're Ngāti Kahungunu, they're specific... In saying that, that's only an issue when you're talking about specific rohe issues, otherwise we could all be urban Māori.”

Jorgette

For Jorgette, Kahungunu identity is not necessarily expressed as a consequence of being raised particularly Kahungunu, being in a Kahungunu tribal environment or as a reaction to being 'Māori-ised' in the city. It is an identity summoned in context, in specific spaces where discussions on iwi development transpire and in atmospheres that politicise taiwhenua concerns - issues which directly affect Jorgette, her whānau and her people.

Although Kahungunutanga is extended and articulated in Wellington by some Kahungunu, it is done through a process of negotiation. Even for my interviewees who self-identify as being essentially Kahungunu, as an articulation it is an identity sieved through the fabric of space and time. For example, the degree to which Cellia's audience self-identifies as Kahungunu influences her type of engagement with them and

76 Kahungunu-Māori will be used throughout the rest of this thesis to imply those who mainly emphasise their Kahungunu identity over other iwi, Māori or ethnic affiliations. 
consequently her sense of connectivity to them. This may imply that Kahungunutanga does not need to be in a permanent state of privileging or centricity. Although it may always be ontologically present, performatively speaking, Kahungunutanga is flexibly and strategically deployed. Others, too, spoke about articulating Kahungunutanga in relation to audience and with regard to specific time and space:

[Interviewer: How (do) you think you were able to express a distinctly Ngāti Kahungunu identity while living here (in Wellington)?]

"Um, well probably only through song really and that's only in a very limited time and space where you might have a pōwhiri and... someone wants to get up and sing 'Pinepine Te Kura'... which is just so Kahungunu. And that's when you could say... I'm specifically Kahungunu here. And you're saying it in such a way that only a Māori audience or an audience that knows a Māori culture would know because a) you gotta know the language and b) you gotta know where the song is from... So you're sending a specific message to a specific audience."

Jorgette

In viewing Wellington as a multi-tribal and pan-Māori space, Kahungunutanga is performed in ways that call for deliberate articulations of identity in order to identify and distinguish oneself as Kahungunu and to show solidarity with Kahungunu others. Conventional markers of articulating collective identity in Māoridom include singing particular waiata. In the Kahungunu case, one would choose waiata specific to Kahungunu which would then locate and classify Kahungunu in, what Tamati described as, "a sea of diversity". But, as Jorgette notes, such an articulation is only necessary in certain situations, when one wants the message of 'Ko Kahungunu au' to be received.

\section{ii. 'Being' Kahungunu in the Workplace}

As much as some of my interviewees who moved to Wellington later in life from Kahungunu rohe are more likely to extend their Kahungunutanga, they are careful not to transplant it in spaces that feel customarily and culturally out of context. Some who did relocate to Wellington did so for secured employment - many of which were positions working with and on behalf of Māori in government or the public sector. In such a work environment, interviewees expressed feeling the need to place their iwitanga 'on halt' to represent the 'Māori voice'. Tamati explained: 
"Because I'm representing and working for the good of all Māori, in doing this there is that potential for me to forget who I actually am... [G]oing home and keeping those links very much alive helps me to keep centred and... keeping me centred helps me to keep focused on who I am, what I'm doing and why I'm doing it for everyone. Because it's a myth, you know. Māori is a myth... there's no such thing. If you were to ask me: who are you? That's what I would say: I'm Rākaipaaka. I am Kahungunu.”

Tamati

In working for Māori as a Kahungunu/Rākaipaaka-Māori, Tamati avoids being completely absorbed by the Māori label in Wellington by exercising his iwitanga elsewhere - preferably on his tribal marae. His involvement with his iwi and frequent visits home help ground him to his iwitanga. Thus, Tamati articulates his Kahungunutanga by extending himself home, literally; indeed, by returning there to get the 'cultural fix' that vitalises his spirit and centres him in a way that is culturally familiar and right to him.

AT is an agent in choosing when and where to (de)activate her Kahungunu identity. She stated:

"I don't take my Kahungunutanga into work. I leave it at home. And I choose... to leave it there because I'm coming into another environment that is foreign, I guess to my Kahungunutanga. But in saying that...my Kahungunutanga will never leave me. I just choose to park it up and I become this, this other person."

[Interviewer: And why do you do that?]

Safety, mainly... I may come into conflict with another tribal area. And it's just to keep yourself safe in terms of your tikanga, your hap $\bar{u}$ - your whānau, hapū, iwi. Yeah, it's a safety mechanism really."

For AT, her Kahungunutanga is not a consistently expressible identity, especially where it is vulnerable, such as in public, non-Kahungunu and non-Māori spheres. It is an identity to be guarded and articulated in exclusive settings and at her discretion. 
Cultural transplantation across intra-Māori lines can indeed occur when Wellington is collectively engaged with as a politically neutral tribal space. Although Māori customary concepts such as tangata whenua-manuhiri are applied in occupational settings that attempt to incorporate bi-cultural principles, acknowledging the differences within the Māori world, there are instances when they may not be enforced by Māori groups. Jorgette explained:

"Ngāti Toa. I know they're the tangata whenua here, and Te Ati Awa. But really this is government land. This is Ngāti Kāwanatanga... Wellington is just dominated to me... Having worked for government I've seen how you... say the kawa is Ngāti Toa and then you watch your manuhiri come and take over."

Jorgette

The public work space in the Wellington CBD may seem too artificial to Māori culture. Consequently, some Māori may overlook the fact that Wellington city is indeed tribally occupied by local tangata whenua. They may interpret it instead as mostly a government space, causing some Māori groups to conduct things specific to their own tribal way, in certain contexts, and disregarding the authority of local tribal groups.

\section{iii. 'Being' Kahungunu: Manuhiri or Tangata Whenua?}

"The more strongly a tribal identity is imposed" says Maaka, "the greater the emphasis on the tangata whenua - manuhiri 'host-visitor' relationship [is] in the interaction between people as individuals and as groups" (1994:315; emphasis in original). For Kahungunu-Māori in Wellington especially, inter-tribal politics and Māori customs take precedence over the imposition, maintenance and expression of a distinctly Kahungunu identity. Wellington is not necessarily a neutral territory to be filled by the cultural pluralisms of its incumbent immigrant communities, nor is it merely, to borrow Clifford's description of the city, a "white enclave" (2001:471) of Pākehā culture and government institutions. It is a layered space of meaning and belonging. On the whole, my interviewees understand that, for example, to implant their own kawa publicly in Wellington, or to take natural resources in bulk from the area without local permission, challenges the tangata whenua-manuhiri dichotomy and, at worst, belittles Te Ati Awa, Ngāti Toa or Ngāti Raukawa mana. For instance, a few interviewees spoke of not fishing in large amounts around Wellington without first asking permission from local iwi marae. 
Thus, living in other tribal lands poses a delicate balance between not 'losing' ones Kahungunu-Māori self, but at the same time not imposing cultural elements that reflect ones Kahungunutanga in spaces where it ought to not be articulated at the expense of another groups' mana.

Many of my Kahungunu-Māori participants are very aware of being manuhiri in Wellington and take that role seriously, as they are knowledgeable of the responsibilities such a position entails. Because Kahungunu-Māori are careful not to trample the mana of Wellington's tribal tangata whenua, summoning one's Kahungunutanga cannot be done without honouring and regulating their relationship with local tribes. For instance:

[Interviewer: Do you ever feel like you're a manuhiri here (in Wellington)?]

"Yup, 'cause this is their land. This is their whenua and I acknowledge... that I'm just a visitor in their land and that I pay homage to them that they allow me to stay here."

[Interviewer: How?]

"Um, I acknowledge them whenever I see them... [I]f there's a pōwhiri or a whakatau somewhere I'll acknowledge them as the tangata whenua. In my atārangi class I always acknowledge them as the tangata whenua of this rohe. You know, it's just a respect thing for them to allow me to be able to stay here."

The tangata whenua-manuhiri relationship is a complex one and is understood differently amongst my interviewees. For AT, she truly feels herself to be just a visitor to Wellington and on the lands of Te Ati Awa, Ngāti Toa and Ngāti Raukawa. And so, her Kahungunutanga is expressed accordingly. Those in Wellington who maintain active links to a Kahungunu home are quite comfortable being manuhiri in Wellington because they feel grounded and completely at home elsewhere.

There are different dimensions to the question of whether one self-identifies as manuhiri in Wellington. For Cellia, classic cultural markers - such as the presence of a marae - that sustain the tangata whenua-manuhiri roles influence how and when she feels foreign on other tribal grounds. She stated:

"Welling-town has no marae, so I feel that they lack tūrangawaewae within Wellington. I mean, we do have Pipitea marae but that was built by... urban 
Māori I guess... for the Māori who live in Wellington... When I go to the Hutt Valley, I feel more of a manuhiri because they have mana whenua marae, real ones... whereas Wellington has got nothing... in Welling-town... I feel quite comfortable in town and quite comfortable in Porirua, but less comfortable in the Hutt Valley because of their papa kāinga, hau kāinga, real marae-maraes [sic] as opposed to urban marae."

\section{Cellia}

'Welling-town', or Wellington city is not viewed by Cellia as the traditional space of any particular tribal culture, and so, it is tribally 'safer' and 'neutral' since it lacks conventional and recognisable cultural staples of a tribal domain. Having quite explicit signs of 'traditional' Māori culture and kawa remind Cellia that she is, in fact, a guest in another tribe's territory.

Some interviewees who grew up in Wellington or lived there for a long time did not necessarily express feeling like manuhiri there. While they are not officially tribal tangata whenua of Wellington, they are a form of 'naturalised' host, either by adopting Wellington as home through choice or circumstance, marrying into mana whenua, or having had and raised children in Wellington ${ }^{77}$. For example, Cellia told me of a kuia from Wairoa who spent 60 years of her life in Wellington:

"She said to me that she felt that she was from Upper Hutt because she had spent more of her life in Upper Hutt than in Wairoa. Although she still called [Wairoa] home it wasn't where I guess she felt comfortable... She felt really comfortable in the community in the Hutt... Her children, as far as they're concerned they're from Hutt, from Wellington... And so they've made themselves be tangata whenua through their kids."

Cellia

For some Kahungunu in Wellington who feel that their tribal identity is not their dominant culture, the tangata whenua-manuhiri custom in not as apparent, solidified nor relevant in their lives. Some of them prefer to emphasise the host-visitor roles only in certain contexts that are meaningful to Māori culture. Jamee expressed:

77 See Chapter Four for further examples of some Kahungunu feeling like tangata whenua of Wellington. 
"Well I've always stated since I was a kid that I'm a Wellingtonian so I am tangata whenua, but I just think that it's different elements... [L]ike I went to [a] marae at Island Bay, Tapu Te Ranga, and I was treated like manuhiri there, even though it's in Wellington. But that's fine because... it's a sacred Māori custom. So I'm just sticking to customs."

Jamee Jamee's relationship to Wellington points out that tangata whenua-manuhiri roles are more complex than when taken at face value. Although tribally, he is manuhiri, on a socio-historic level, he feels himself to be tangata whenua of Wellington. Nonetheless, articulations of being either manuhiri or tangata whenua are layered and dependent upon spatial context and personal identification.

\section{On 'Not Being' Kahungunu in Wellington}

\section{i. Kahungunutanga from the 'Inside', 'Outside' and 'Side-line'}

As much as demonstrations of Kahungunutanga can serve as identification qualifiers for Māori, when used amongst Kahungunu, they can be applied as authenticating tools. Those who feel grounded in their Kahungunutanga summon types of identity articulations other than the singing of waiata or the carrying-out of kawa. They rely on demonstrating basic knowledge of back-home, and on possessing surnames commonly associated to Kahungunu. Te Hiwi stated:

"Well [in] Upper Hutt, I have met some people... who claim to be from Ngāti Kahungunu but I like to think otherwise... When I just talk to them about things that are commonly related to Kahungunu or the Hawke's Bay they just don't have any gist of it. And when I ask them, 'Oh, what are your family names?', I'm like, 'Oh I've never heard of those families before'... You usually have those common Māori family names that you're usually accustomed to for each area... you usually assimilate [sic] people to what their last names are... but I just think it's because they haven't been brought up on that [Kahungunu] side of the family... That's why I'm a bit iffy, 'cause I'm Kahungunu at heart." 
According to this idea, the degree to which one privileges one's Kahungunu identity or is aware of one's Kahungunu culture influences how one in turn is recognised and accepted as Kahungunu, by other Kahungunu. To engage as Kahungunu, one is to demonstrate one's environmental and cultural literacy by producing recognisable 'signs' that identify one as being Kahungunu, such as family names and 'common' knowledge of Kahungunu. For Te Hiwi and others whose Kahungunutanga is at the centre of their identity, they may summon conventional cultural markers to locate one's Kahungunutanga - markers which deem one more 'culturally attuned' to Kahungunu and perhaps, more authentic.

Some interviewees spoke of intangible, intuitive forces which pull them towards connecting with other Kahungunu in Wellington and aligning themselves specifically with those of their iwi. Lisa shared:

"I think you are drawn to your own... So sometimes I think you're drawn to your own because you know [they're Kahungunu]. But even then, you're still drawn at some level to start off with. And then there are the others that you don't know how you're linked but you're still drawn... whether I think it's spiritually or whatever or ancestral... And then some of them...it might be a conscious, 'Oh hey cuz!' 'Oh hey!' But then you know you may have similar traits... And you get on well 'cause you're both relaxed and you both laugh a lot... \{Laughs\} I don't know if that's a Kahungunu trait or not."

There are spiritual bonds that attach Kahungunu together and which, at the very least for Lisa, reveal themselves at some points in the life journey. In the case of Lisa, this works to validate and develop her sense of belonging to Kahungunu. Even amongst Kahungunu, Lisa spoke of being drawn more specifically to those of Rongomaiwahine descent and from Te Māhia Peninsula versus from other areas of Kahungunu. As much as the ancestral bonds and the energies they transmit can attest to the permanency and extratemporality of Kahungunu identities, they may also be reflective of the diasporic person's desire for home and to be closer to (people from and elements of) home.

As much as articulations of Kahungunutanga are derived contextually, they are also fact-dependent, being fuelled by one's knowledge of Kahungunu ancestry and culture. A few interviewees expressed not knowing much of their Kahungunutanga throughout most 
of their life, as they were raised isolated from their Kahungunu marae, alienated from ancestral knowledge, and so forth. Consequently, some interviewees chose to delve into exploring the meaning of claiming a Kahungunu identity later in life. For some who were not raised with a 'developed' Kahungunu sense of self, their voyages into Kahungunutanga came via cultural treks through Māoritanga, first $^{78}$.

Four participants from this study described growing-up culturally Pākehā, choosing to explore and develop a Māori identity only after leaving home in late- or postadolescence. Jamee was purposefully kept from his Kahungunutanga, and so accessing the living memory of his Kahungunu heritage proved more difficult as an adult. His cultural centre is not his iwitanga per se, since he grew up believing he was mainly Wellingtonian. Today, however, his association and connection to his Kahungunutanga is developing through exploring his Māori identity, mainly at university, through pan-Māori groups and through Māori friends in Wellington. Yet, still, an ethnic Māori identity is of much more relevance in his daily lived experience in Wellington, as opposed to a strictly Kahungunu identity. He affirmed:

"I don't think it's about my iwi or where I come from, even though those are important. I think it's more about being Māori. Obviously Kahungunu is Māori, but I think in general I like to express Māori things... I don't really sort of try to limelight Kahungunu. I just like to limelight, just the Māori way of life.”

Jamee

Although a Māori identity helped expose Jamee to an iwi identity, he still feels more comfortable articulating himself as Māori which reflects his reality of being (treated) different in Wellington by non-Māori. For Jamee, it is not the case that his Kahungunutanga is more 'solid' and more 'true' over a more 'superficial' Māori or even Wellingtonian identity, but that they are all needed and equally valid experiences in his daily navigations through life. He may merely represent them mostly under the cloak of Māori.

78 In the context of migrant Native Americans to urban centres in the United States, Straus and Valentino explain this focalisation of identity outside of tribal contexts: "Now, Indian people growing up in a city, always aware and respectful of tribal affiliation, may look first to a positive Indian identity, supported by connection with Indian organizations and community, and, from that base, move forward to a real connection with tribe, often selecting among the several that comprise their heritage" (2001:93). 
For others, a Kahungunu consciousness does not necessarily mean a stringent focalisation to 'being' either Māori or Kahungunu, nor does it equate to prioritising 'performing' these identities over experiencing them. Challen spoke about intentional and focused identity articulations as distractions from simply living the identity. According to her, forced articulations are too concerned with the element of performativity ${ }^{79}$ and its consequential process of authentication. She stated:

"Definitely for my very close friend...we're just on the same wavelength about how we feel as being Māori and she's way more involved in the Māori community than I am. She can go to hui and go talk in Māori and converse and do things, all the ritual things you're supposed to do, the formalities and then come out and go, 'I don't even know what I was just doing there.' You know, she's copying someone copying someone copying someone...she's performing...it feels like performing, performing as Māori, demonstrating our Māoriness rather than experiencing it."

Challen

Challen's articulations of cultural identity are not bound by public, theatrical displays of specific cultural choreography. She does not want to be limited by stringent ways in which identity is expected to be expressed in order for one to be recognised, acknowledged and accepted as Māori or as Kahungunu. Instead, her concern is more with letting her identities speak to and through her, organically. Challen's experiences with her whakapapa are not of a conventional nature, and thus, many times have the effect of culturally silencing, socially excluding and marginalising her from participating in Māori or Kahungunu communities. She added:

"At some point this year I decided that I wanted to pay an ode to every single iwi that I whakapapa'd [sic] to in my story-telling... [T] hat's my connection rather than what other people do: stay at the marae or go back home and do wānangas [sic] and stuff. I don't really feel like I even have to move out of my seat to have an experience with my whakapapa. It just happens that they come in dreams and they come in other forms to me, and that's really... unexplainable to a wider

79 Performativity argues that identities are brought into being through their performance, meaning that they are sustained through acts and mannerisms that reproduce the notion of what that identity constitutes (Hubbard et al. 2004:348). 
community who go, 'the way through to your culture is through the language like through the reo - and is through going home', and my experience... and my relationship with my culture isn't defined like that."

Challen

As a result of not conforming to conventional models of conspicuously articulating Māoritanga or iwitanga, Challen expressed feelings of discomfort and alienation from adjacent communities, believing them to not be accepting of alternative expressions of those identities which indeed reflect her own personal, meaningful journey. Nonetheless, her hope is to expand understandings of identity and open-up channels for discussion about them through creative writing and the performing arts. In the same way that artistic realms are creative, Challen's point is that identity too is a creative, constantly unfolding endeavour.

\section{ii. Kahungunu Identity to Kahungunu Difference}

Not only do inter-tribal customs and a pan-Māori identity work to regulate Kahungunu articulations in the Wellington diaspora, so too do intra-Kahungunu politics. Kahungunu identity espouses a strong, one-iwi ethic and many summon the relevance of Te Huki's Net to describe the 'inherent' unity and alliances that overshadow Kahungunu differences. However, such an ideal glosses over the internal strife that transpires intratribally and its significance. Kidman states that "tribal unity is often a romantic ideal rather than an on-the-ground reality...[and] conflict and debate can provide the sparkle that mobilizes a dynamic community" (2007:15). Kahungunu identity is more often than not, packaged as an all-encompassing, unanimous singularity which contradicts what my participants expressed in regards to upholding their tribal mana and their rights to difference.

Kahungunu is a conglomeration of group difference with sub-parts engaged in processes of mediation, that sometimes align in common objectives while at other times work through dissimilarities and colliding interests. It is an identity that many times is pitted against its own difference. AT expressed:

"I've always been brought up knowing that I was Rongomaiwahine on my dad's side and on my mum's side it's Kahungunu. But now, now that Kahungunu has taken over the Rongomaiwahine.... area there's this bit of argy-bargy happening... 
It's like, 'No, we're Kahungunu!', or 'No, we're Rongomaiwahine!' But whenever I stand up I always acknowledge Rongomaiwahine. She was the lady... she had the mana up there... I don't know why you guys take over her because she had it."

In distinguishing her Rongomaiwahine lineage and cultural identity from that of her Kahungunu heritage, AT is making a political statement of difference and of resistance. For her, she belongs to two separate iwi that have been conjoined at one level disproportionately and counter-factually, so that one's mana (Kahungunu) is acknowledged and esteemed over the other's (Rongomaiwahine). AT descends from the line of Rongomaiwahine prior to the latter's union with Kahungunu, and considers Rongomaiwahine's mana to have been greater than his. Therefore, to deny or allow her Rongomaiwahinetanga to be subsumed under her Kahungunutanga is to negate the mana of the former group and its tippuna. Although Rongomaiwahine has been formally made part of the Kahungunu iwi, AT's acts of resistance prevail and are unveiled in opportune settings where she privileges the subjugated ancestral line. Irrespective of the 'official' story, AT humbles her Kahungunutanga to her Rongomaiwahinetanga so that the latter does not get lost in perhaps a form of inter/intra-tribal domination in the name of unity and identity.

For Tamati, both Kahungunutanga and Rākaipaakatanga basically sit at an even keel and are summoned when needed. Consequently, his Kahungunutanga is not articulated in a way that absorbs and represents his other iwi and hapū affiliations. He stated:

"I see myself as Kahungunu. I see myself primarily as Rākaipaaka... What I don't like is the way that Kahungunutanga has been imposed over the top of my Rākaipaakatanga and in doing so takes precedence over that... Now we're all Māori... who belong to iwi and those are the two things that they [the Crown] can control... and in doing so construct this hierarchy that enables the Crown to interact, to control and/or to manage... So that's what I don't like about Kahungunutanga, that it's a result of that. And what we have forgotten is how we relate." 
Tamati sees the absorption of Rākaipaaka iwi into Kahungunu as an act generated by and sustained through colonialism; it is a political move encouraged by the Crown and enforced by the current rūnanga system. While the reasons may include easily managing related groups and centralising control of resources around Kahungunu territory, it nonetheless influences the way people self-identify and for some, may even threaten to eclipse identities they deem sacred.

All of my interviewees named iwi, other than Kahungunu, to which they affiliate and identify, not excluding ethnic groups, as well. Thus, we must keep in mind that there is no clean and tidy definition of 'being' Kahungunu since my participants demonstrate multiple iwi, hapū and group affiliations that on some level influence their Kahungunutanga. But, similar to their ancestors, they continue a dynamic process of navigating between all their identities. AT who is proudly Kahungunu, Rongomaiwahine, Ngāi Tahu and Scottish equally, wholly and respectfully, expresses how moving through her multiple heritages prepared her for living in Australia and Greece:

"It's quite interesting how we can bounce in and out of our heritage...quite calmly. You know we do it all the time, and... we can sit in many worlds with different cultures and we accept how they are and we can... cruise around and do what they do, you know, do what the Romans do on their turf. And, and I'm quite used to doing that because I've had to do it. I've just grown up in it."

It is normal for AT to navigate between worlds of difference since her experiences have always been about compromise, acceptance and even 'battling' between her multiple identities. According to Tamati, the consequences of colonialism have meant that contemporary Māori have lost the flexibility their ancestors possessed to shift between identities, and that that inflexibility has become a normality in Māori society. He explained:

"What we've lost is that flexibility, that... ability to look at our differences. The sum total of these differences is what makes me strong... The Pākehā influence says, one way, or the other. But when you look back through our history our people were much, much more flexible than that: on a Monday they could have been Ngāti Y, on a Tuesday they could have been Ngāti X and on a Thursday they 
could have been Ngāti $Z$, depending on the context of the situation. But nowadays... you have to choose... Nowadays, we all go to one marae... That's amplified when you come into an urban situation, there's only one way, that's the Kahungunu way. Kei te pai. I understand that. The challenge is at that level to realise and accept those differences."

Tamati

My participants' experiences with articulating different ways of 'being' Kahungunu perhaps demonstrate that a similar kind of dynamism lived in pre-colonial days (Maaka 2003; Mead 2003; Poata-Smith 2004) continues to be used as a process of cultural continuation and survival across circumstance and context. Moreover, it exemplifies their agency to self-determine. Nonetheless, the challenge still remains to 'normalise' those processes of intra-group mediation and difference on a collective level (of iwi).

\section{On 'Becoming' Kahungunu: The 'Third Space of Forms'}

Different forms of Kahungunu consciousness are experienced and articulated in the Wellington diaspora that extend and expand Kahungunutanga through conventional and unconventional ways. Not only can Kahungunutanga be a state of 'being' through its activation and a state of 'non-being' in its dormancy, it is a state of 'becoming' that unfolds. Accordingly, identity is never a finished product or an "already accomplished fact" (Hall 1993:392) which ones cultural practices validate and behavior, replicate time and time again. Yet, while social identity may be a process (Poata-Smith 2004:179) and a production (Hall 1993:393), for my interviewees, it is also a birthright. AT's experience attests:

"I didn't learn [Kahungunutanga]. It was already embedded in me and all I had to do was just - you know how you water a plant and it grows - yeah, all I had to do was water it and it'll bloom but within me... It's just there. It will always be there... and at certain times I would water and nurture it to make it grow within me. And it will never leave me. It will always be there, as well as my Scottish heritage, Ngāi Tahu heritage and my Rongomaiwahine heritage; it's already ingrained in me." 
AT's analogy of her Kahungunutanga being a plant that is always present and always alive depicts well the process of 'becoming' Kahungunu. Although Kahungunutanga is a state of 'being' that Kahungunu people may claim, it is not identical for all Kahungunu. Thus, there is no singular, one-dimensional way of learning, knowing, experiencing, expressing and 'being' Kahungunu. It is just as much moulded by the journey of the individual as it is by the voyage of the collective.

Collective identity largely implies cohesion of the whole and non-deviation by its constitutive parts, providing a tight script to follow and a tidy definition to embody. Yet, Kahungunu identity, on the whole, is dynamic, living and shaped by (its) difference. Thus, to speak of it as an identity might not do justice to capturing its multiplicity or accommodating for its 'jerks', 'twitches', and the alternative ways in which it is mobilised and spoken of. Brubaker and Cooper (2000) argue that 'identity' is forced to do too much and to compensate for alternative descriptors that can be more appropriate. They note that 'identity' is applied in contradictory ways. For example, 'identity' can be used to demonstrate the ways in which the idea of sameness unites people through commonly shared elements (2000:7). On the other hand, it can be used to deny the very existence of any foundation, of any core. In this sense, 'identity' emphasises the self and the group as fragmented, unpredictable, contextual, perpetually changing and essentially different (2000:8). These usages of 'identity' are not simply heterogeneous. Brubaker and Cooper argue that they point in sharply different directions (2000:8). Thus, 'identity' is clearly a heavy term that is expected to do a lot, covering an unnecessarily large amount of ground.

To interrogate and particularise identity in a Māori context is to speak to a commonality of experiences shaped by indigeneity and its resultant conditions. Yet, as much as identity in a Māori context stresses difference between Māori and non-Māori, it also emphasises sameness amongst Māori. Manuhuia Barcham (2000) deconstructs the relationship between Māori identity and Māori difference, claiming that the former rejects emergent forms of the latter despite social transformation and cultural change within the population. He says that Māori identity is superimposed and desired over Māori difference by government and many Māori, which detracts from and invalidates concurrent processes of cultural movement, change and their consequential meanings. He 
states, "The prioritisation of identity over difference hassled to the creation of an existential dichotomy of being and non-being...has effectively excluded recognition of the dynamic process of becoming" (Barcham 2000:138; emphasis in original). As a consequence of the Enlightenment project, Barcham believes difference gets subordinated under the banner of identity and is a condition currently internalised by Māori people in relation to colonialism. Perhaps at times, Kahungunu identity gets superimposed over examples of its own difference, in a similar way to what, Barcham argues, happens to Māori identity and Māori difference.

On the other hand, we should be careful not to lose ourselves in the discourse of difference, especially in regards to tribal identity. For many, tribal identity is founded upon unchallengeable elements of whakapapa and place identity - elements which are deeply embedded in the immaterial, materialised and embodied connections of people to each other, to particular areas and to events which continue to inform their identities. We must also be careful not to fall under structuralism's 'spell' of either/or discourse which can binarily oppose and essentalise identity and difference; for, both find elements of the other in their composition and are equally as valid and functional in the lives of my interviewees. Nevertheless, Barcham's invocation of the idea of 'becoming' is useful here as an analytic and descriptive tool for Kahungunutanga since it can accommodate for the non-subordinate co-existence of difference and identity within diasporic articulations of Kahungunutanga. Thus, I extend Barcham's suggestion of re-directing focus to a third space "of 'becoming', wherein neither notion of identity nor difference is prioritised over the other ... [as it] opens up the possibility of cultural identity that entertains difference without the assumption of a temporal hierarchy" (2000:148).

The third space of 'becoming' is not one that denies 'beingness'. It simply allows infinite room for Kahungunu to express and expand on notions of 'being'. As such, it is a space that is neither 'rigid' like identity, nor 'chaotic' like difference, but moveable and mouldable by personal choice and/or by external circumstance. Challen expressed:

"It's not until right now that I've realised how important it is for me to be so mobile and chameleon-like to fit into different parts of myself and go, then being like really solidly this square. I'm like a star-shape I suspect... It definitely 
doesn't help me to narrow down the possibilities of who I am but more so... keep the constant changing and moving nature of myself, as who I am.”

\section{Challen}

Challen's star-shape analogy is useful here in two ways: firstly, to point out the importance of intra-Kahungunu difference and secondly, to demarcate the directions of Kahungunu movement through the diasporic state of dispersion, where members of the group travel in different directions to connected points away from the core. Perhaps a square can best describe the fine, neat lines of Kahungunu identity, its constructed conventionality, its centredness and the 'beingness' of the tribe, in general. The star can represent a diasporic state of difference, of unconventionality and unpredictability, a noncentre and state of 'non-beingness'.

Both the square and the star are but possible representations of Kahungunu identity and Kahungunu difference for my interviewees. They are both equally as valid and can also be equally as limiting if seen as separate, isolated and incompatible spheres. It is here that Articulation theory may be useful in making sense of two needed parts whose combined effects can help explain contemporary Kahungunutanga. Articulation theory, as Jennifer Daryl Slack explains, is "the sign that speaks of other possibilities, of other ways of theorizing the elements of a social formation and the relations that constitute it not simply as relations of correspondence (that is, as reductionist and essentialist) but also as relations of non-correspondence and contradiction, and how these relations constitute entities" (1996:117). Seen in this light, Articulation theory marries seeming contradictions - Kahungunu identity and Kahungunu difference - and helps make sense of them in a coherent matter. It positions them together, as a collection of centripetal and centrifugal forces that have a "tendency towards unification on the basis of certain shared characteristics counterbalanced by a propensity for fragmentation due to the unavoidable differences which separate" (Clarke 2006:41). In the context of this thesis, Kahungunu identity and 'being' and Kahungunu difference and 'non-being' work together and play with each other to constitute a Kahungunu 'entity of becoming' - a Kahungunu articulation, so to speak. And so, Kahungunu difference is not a disarticulation of Kahungunu identity, or vice-versa. They are each others' conduit; conjoined parts of 
'same' and 'other' which constitute what Articulation theory refers to as a 'unity', but what I prefer to designate as a 'form'.

I propose to conceptualise a third space of Kahungunu 'becomingness', not as a set shape, either solely a square or a star, but as a 'form' that acts as a membrane - one that hums through vibrations and moves in circling waves along an outline that is always existent, but never as it was just a moment ago. In this way, Kahungunu identity and Kahungunu difference conjoin to articulate Kahungunu forms ${ }^{80}$. Technically, forms are shapes with an outline that, in a Kahungunu context, could be whakapapa and ancestral tūrangawaewae. Yet, they take shape as determined by their internal substance and external environment. Forms are not bound to any one particular shape as they expand or deflate, mould and flex to assume various shapes and sizes for and by their surroundings. Forms carry evidence of history, marks of the present and contort to possible futures. They possess moving or warping centres that appear, disappear and reappear when needed. Their surfaces move and act like a membrane that is malleable, pliable and even 'bleeds' in certain spots allowing for points of difference to infiltrate, affect and (in)form. In the end, we are left with the "open-endedness of an unfinished project, the moving equilibrium" (Mendoza 2002:202). The participants of this study are embodied articulations of Kahungunu forms, always and forever 'becoming'.

80 Not to be confused with Plato's Theory of Forms. 


\section{Chapter Four: Home}

"From the diaspora perspective, identity has many imagined 'homes'... it has many different ways of 'being at home'... but is not tied to one, particular place."

Stuart Hall ${ }^{81}$

"Ehara taku maunga i te maunga haere." - 'My mountain is not a mountain that moves.'

Māori proverb ${ }^{82}$

\section{Māori Home}

Home is a concept that is intimate and familiar to most of us. It is a reality we experience objectively and subjectively, as public or private, common or personal. Thus, it can be interpreted in a range of ways (physically, emotionally, socially, spiritually, metaphorically) and on multiple levels (historic, national, ethnic, religious, familial, and so on). Experiences, ideas and senses of home are intricately tied to journeys across the terrains of many cultural identities. Yet, as the above quotes attest, identifying what is 'home' and where it is located is not necessarily straightforward. This is true in the context of Ngāti Kahungunu members in Wellington who may be undeniably tied to particular ancestral places, but who are also shaped by their 'homing ${ }^{83}$ of environments external to Kahungunu, all which take part in the life process of their 'becoming'.

Through my understandings of spatial belonging in Māori epistemology, home is generally located over specific historical locations embodied in the physicality of a space. For example, one's mountain, lake, river, marae and other physical features indicate a place as home. Mead (2003) explains how descent-based relationships represented in and as tribal units are but a single pillar in the socio-historical complex of tribal continuity. He states that the spiritual essence, unchallengeable voice, and (im)material subsistence of the group must be found in and unfold primarily over specific traditional territories, binding people not only to each other and to their ancestors, but to a particular land as well (2003:272). Over generations, important stories and events get embedded in the landscape (Smith 2007:38) making it a physical place that, if read correctly, articulates

\footnotetext{
81 In Hall (1995:207).

82 This proverb was extracted from Maaka (1994:327), but a similar version can be found in Mead and Grove (2001:22): "Ehara a Hikurangi i te maunga haere”, or 'Hikurangi is not a traveling mountain'.

83 'Homing' is used here to imply a process of making home somewhere.
} 
tribal history and identity. In short, ancestral land embodies the spirit of the tribe and becomes itself a living ancestor (Douglas 1983:2) that needs to be protected, nurtured, honoured and cherished into the future.

From the opening quotes above, the second perhaps demonstrates the "nonexportability of the tribal essence" (Maaka 1994:327) and its rootedness to the confines of specific tribal place, such that through its location and environment, one's identity is defined sui generis. However, in the first quote, Hall (1995) questions the presence and permanency of an essential 'home' in the diasporic life and its containment within the borders of specific places. Although marked by place, one is not bound or completely determined by it; the 'diasporic personality' is unobstructed by place. Moreover, "because it is spatially located, but imagined as belonging not to one but to several different places, the diaspora idea actively contests the way in which place has been traditionally inserted into the story of culture and identity" (Hall 1995:207). This chapter delves into the many interpretations and meanings of home for my interviewees and how dimensions of place, space and time influence their Kahungunutanga.

A whakapapa framework grounded in mātauranga Māori, or Māori philosophy can help clarify some assumptions of the diasporic as 'rootless' and of tribe as essentially and only 'rooted', to re-configure home and re-conceptualise belongingness through the experiences of some Kahungunu in Wellington. For instance, as a result of living away from one's hau kāinga, or place of origin, some Kahungunu feel excluded from it and the tribe while having the desire to be (more) involved. We can benefit from Carter's (2006) understanding of continued connections to tribe and to tribal place through Māori concepts that accommodate for tribal members not residing upon their hau kāinga. To do so, it is important to first understand the idea of ahi kā (roa), or (long) burning fires, and its endogenous principles, which will be explored shortly.

\section{i. Roots of Home: Ahi Kā (Roa)}

In the Māori world, cultural identity is intimately tied to place identity making spatial dimensions significant elements in a collective narrative. In a tribal context, the attachment of people to each other and to their ancestral homeland is literally umbilical, 
as the word 'whenua' denotes both land and placenta ${ }^{84}$ (Carter 2006:34; Mead 2003:269). Historically, identifying a place as belonging to a specific tribe was determined through the claiming and continual occupation of land by tribal members, who subsequently derived spiritual, socio-cultural and physical sustenance from it. The metaphor of ahi kā (roa) expresses the idea of home fires, of occupying an internally and externally recognised territory for at least three generations (Asher and Naulls 1987:6). Although Mead (2003:279) states that this concept was unnaturally elevated by the Native Land Court, the mana of the tribe was nonetheless associated with the 'owning' of and caring for this ancestral home (Walker 1982:70). Toitu Te Whenua notes that ahi tere, or wandering fires, refers to those who live away from their tribal territory for a given length of time, making their right over the land unstable (1959:43). Yet, he also states that "if fires were ahi-tere, they could be ahi-ka, if the person concerned returned to live in the tribal area" (Te Whenua 1959:43). However, if the group or one of its members ceased to occupy the papa kāinga and care for it for three consecutive generations, their fires would be permanently extinguished (Asher and Naulls 1987:6). This would make their mana over the area obsolete and deny them status as mana whenua ${ }^{85}$. The cessation of occupying a given land and the subsequent loss of customary rights to it is otherwise known as ahi mataotao, cold or extinguished fire (Te Whenua 1959:43). Ahi mataotao implies the loss of a traditional home base, interrupting the right of continuity for a person or people over a particular territory ${ }^{86}$.

Some understandings and uses of ahi kā (roa), ahi tere and ahi mataotao vary, leading to different, sometimes contested conclusions. For instance, Mead states that "the notion of ahikāroa is not consistent with the idea of seasonal occupation when groups moved from one place to another to harvest a food source at the right season" (2003:279). He explains that the idea of ahi kā (roa) received permanency in post-settler New Zealand

84 Traditionally, the bodily connection one has with one's ancestral land is articulated through the practice of burying a piece of one's umbilical cord in the ground, or hiding it in a tree or cliff (Mead 2003:269-270).

85 Although the meaning of the term is contentious, mana whenua broadly denotes customary authority over an area. However, it is constructed anthropocentrically because it lends less credence to the concept of whenua and more to that of tangata.

86 Ahi mataotao does not necessarily imply that the 'lost' home would not play a role or have significance in the biography of the tribe. Nor does it imply that a home base was not or would not be claimed elsewhere, especially since, as Maaka (1994:327) notes, the association between people and place was central to traditional Māori identity. 
society, when Māori conglomerated into larger whakapapa-based groups over specific territorial blocks. Nevertheless, living away for at least three generations (without intentions to return) to what could have been a seasonal papa kāinga may have equated to a loss of customary custodianship over it. On the other hand, whereas some denote ahi mataotao as implying an extinguished fire, in He Hīnātore ki te Ao Māori. A Glimpse into the Màori World: Mãori Perspectives on Justice (2001:214) ahi tere is equated with the loss of customary lands by allowing the occupational fires to burn out. Yet, others do not bring ahi tere to the extreme of meaning dead fires. For example, Carter (2006) summons it to denote those who simply reside off-rohe, regardless of the length of time, but with intentions nonetheless of returning, or at least contributing to one's tribal-home from afar.

Carter (2006) uses ahi tere in the context of Ngāi Tahu expatriates in Auckland, who although residing away from their hau kāinga in the South Island, should not, she argues, lose their rights over the land nor their voice in the tribe. In the context of her research, subjects maintained their connections with their ancestral tribal place despite a physical distance from it. Carter employs the concept of ahi $k \bar{a}^{87}$ to explain connectedness between tribal members and their hau kāinga, notwithstanding iwi members who dwell outside their ancestral territory, temporarily or permanently. She states: "Their fires are burning, but at a distance from the home places" (2006:42), on condition that while away they uphold their "responsibilities and obligations that go with maintaining the land, resources, and growth of the iwi" (2006:42). Carter's use of ahi kā and ahi tere attempt to avoid unfairly excluding those who continue to nurture their hau kāinga and represent their tribe at a distance, outside the context of their traditional tribal place. She specifically speaks to the experiences of Ngāi Tahu in Auckland who organise formally around their tribal identity, and argues that despite not living on their hau kāinga, they have a responsibility to remain "globally connected" (Carter 2006:42) with their iwi.

Perhaps a limitation of Carter's inference is that she lacks addressing the experiences of Ngāi Tahu who are not formally part of a Ngāi Tahu community in Auckland, in order

87 Carter consistently uses 'ahi kaa' instead of 'ahi kaa roa'. Although her reason for using ahi kaa/ahikā instead of ahikaaroa/ahikāroa may be minor, it cannot evade the contested differences between the two versions. Perhaps ahi kā roa can denote a timeframe for keeping alive one's connection to home through the fires being long-burning and thus, insisting on the tri-generational continuity of land occupation. Whereas, ahi kā could assume the connection is perpetually there - provided that in the post-settler New Zealand world it existed at the signing of the Treaty of Waitangi - as the fires are simply burning; such a connection is to be activated when the time is right in one's life. 
to reconcile the complex and subjective layers of the tribal-diasporic experience. For example, some experiences of migration may lead to the weakening or breaking-up of social ties between whanaunga at home and in the diaspora, causing a residual effect on their lived relationship with the tribe and their practical connections to an ancestral tribalhome. What becomes of one's ahi kā (roa) for those who by default are children or greatgrandchildren of a migration from the hau kāinga, and reap the results of a separation from, weakened elasticity to, or possible broken connection to their whānau links there? If they wish to re-connect and re-activate those ties from outside their tribal-home, can their fires be assumed to be out? Can they be rekindled even? How can their voices be heard by and included in the tribe and their roles and responsibilities to it determined?

However contested the term and its implications may be, the concept of ahi kā (roa) remains an ideal of occupation and of customary land title for Māori (Mead 2003:280) as it is used today to regulate relationships in the Māori world. In today's post-settler New Zealand society, ahi kā (roa) is not only of spiritual, socio-cultural and economic significance to Māori, it is of political consequence, too. Today, ahi kā (roa) can be used to claim and protect autochthonous rights to ancestral place as it legitimates tribal rights to construct or perpetuate 'geographies of difference' (Castree 2004:136; Escobar 2001:142). Ahi kā (roa) mediates and guides inter-tribal relations as it designates borders around tribal zones and sustains a system of tangata whenua-host and manuhiri-visitor roles, delineating responsibilities on both sides. Places and roles of 'distinct coherence' (Massey 1999:14) are kept, maintained and legitimated through the possession of land and mana over it. In regards to Crown/iwi relations, ahi kā (roa) can be used to defend the necessity of Māori place-making projects that seek to defend customary rights and title to ancestral areas that remain largely and continually threatened by colonisation and its sustained political and institutional remnants.

Carter contends that contemporary Crown/iwi relationships are based around government and ethnographic interpretations of Māori spatial belonging, encouraging tribal 'freezing' through ideas of timeless roots and restrained locatedness to traditional places (2006:35-37). Through the Treaty settlement processes especially, tribes are compelled to establish their continuing presence upon, their perpetual relationship to, and 
their historic possession of a hau kāinga in order for the Crown to recognise tribal mana over the land. Iwi are to prove:

"an unbroken occupation of the area in order to claim rights and ownership of resources... The principal of ahi kā becomes paramount to validating tribal identity at the expense of other principles of consanguineous participation... [This subsequently] produces a notion of singular places that require that all tribal groups be located within them" (Carter 2006:36; my emphasis).

Carter implies that ahi kā (roa) cannot continue to be understood and used through limited interpretations of it, and despite other Māori principles of belonging. For Carter, the quality of relationship one has with one's hau kāinga and with the people who claim it as home too, versus one's mere presence on the land is of more relevance to the modernday application of ahi kā (roa), not to mention, of more benefit to the tribe. She uses whakapapa principles to detail the innate complexity of ahi kā (roa) and its continued relevance in current diasporic Māori lives ${ }^{88}$.

\section{ii. Home of Roots: Tūrangawaewae}

Coupled with ahi kā (roa) is the concept of tūrangawaewae, or a place for one's feet to stand (Maaka 2003:22; Mead 2003:272). The role of tūrangawaewae is central in the ever continuing and growing story of the tribe and of its members. It is a profound Māori concept of spatial belonging that expresses notions of (communal) connectedness to place. Rangimarie Pere explains its relevance in the Māori worldview:

"Turangawaewae is basically the courtyard or home area of ones ancestors. Where one feels she or he has the right to stand up and be counted. It is the footstool where she or he belongs, where the roots are deep. From this turangawaewae a person can move into any given context, indeed the world knowing that she or he is sure of her or his identity and is not afraid to make a stand" (1991:50).

Tūrangawaewae is a concept that is imagined as much as it is real. It can give one a sense of eternal connectedness to ancestors and to their place of rest. These spatial roots have characteristics of an extension cord that stretch unendingly with the person in and across different places. Taurahere, meaning the rope that binds, perhaps expresses most

88 Whakapapa and its principles will be investigated later in this chapter. 
accurately the idea of unyielding connectedness between people and places, despite movement and change - the type that may manifest through diaspora ${ }^{89}$.

Although one's ancestral marae is a visible expression and central staple of the tūrangawaewae ideal (Douglas 1983:4), today, it is only a single example of tūrangawaewae which has been morphed through the processes and results of colonisation (Smith 2007:257). Takirirangi Smith (2007) explains how colonisation has transformed perceptions of tūrangawaewae, broadening its meaning and usage in contemporary Māori society. He says that today tūrangawaewae can be claimed in spite of place not being one's ancestral and tribal homeland. Smith notes the relevance of $20^{\text {th }}$ century Māori religious movements that "promoted transformed notions of tūrangawaewae to those who had become landless and marginalised through colonisation" (2007: 257). In addition, the contemporary phenomenon of Māori claiming tūrangawaewae through residence and historic 'occupation' of places outside their hau kāinga, as well as through burials in these localities, reveals the dynamism and dimensionality of modern-day tūrangawaewae. Whereas, on the other hand, for tūrangawaewae to be established in pre-colonial times, he notes, one would have to intermarry with those who connected through whakapapa to the local landscape (Smith 2007:257). Smith implies that türangawaewae is not a concept solely tied to the tribal possession of ahi kā (roa), but that like the concept of whakapapa, should be interpreted as a layered and multi-dimensional expression of connection and belonging. He states, "Tūrangawaewae are not fixed territories but are constantly contested and challenged, adjusted and mediated and kept alive... [T] ürangawaewae are organic in the sense that they are constantly evolving" (2007:257-258). Perhaps we can deduce from Smith that possessing ahi kā (roa) is not always a necessary precursor to claim a place as tūrangawaewae - although for many it is still the most specific, predominant, relevant and potent form.

"Tūrangawaewae is always a political statement" states Smith, and is "contextual to power relations within the framework of those who belong and those who are on the outside" (2007:257). It can be used to determine tribal exclusivity through the discourse

89 The concept of taurahere and its use for identifying and describing formally organised diasporic Kahungunu groups will be further examined in Chapter Five. 
of territorial rights. Maaka confirms that whakapapa, ahi kā (roa) and tūrangawaewae encapsulate the idea of tangata whenua which is an essential ingredient in tribalisation (2003:22). Thus, embedded in having a tūrangawaewae is the right to claim oneself as tangata whenua which, in turn, dictates customary codes and practices to follow. However, claiming tūrangawaewae and upholding the role and responsibilities associated with it is relational and contextually-dependent. For example,

"at one level all Māori can declare themselves to be tangata whenua with their tūrangawaewae as Aotearoa, all Māori being descendants of Rangi and Papa and a tipuna that came from Hawaiki to Aotearoa. The notion of tūrangawaewae therefore is dynamic, transformative, contextual and relative to whakapapa kōrero of other tūrangawaewae, which an individual may recognise or identify with" (Smith 2007:258-259).

In other words, in the way that one may have tūrangawaewae in a specific place - such as on a marae - one is tangata whenua within that domain. However, if the marae - be it pan-Māori or of a diasporic tribal community- is located within the 'exclusive' domains of a specific tribal group, outside of the marae context, one is manuhiri and cannot necessarily claim tūrangawaewae in the wider spatial framework. Smith continues to recognise the changing contours of tūrangawaewae through contemporary social formations within Māoridom as he uses the example of gangs who claim to 'own' territories upon differing tribal districts (2007:259). In regards to my interviewees, their claiming of a tūrangawaewae varies from person to person and depends on how one identifies with being Kahungunu and with living in Wellington ${ }^{91}$.

\section{iii. Home Beyond Roots: Tribal Māori in the Diaspora}

Identifying what is home and where it is located for Māori today is not necessarily simple, especially in regards to those who dwell extra-tribally. For example, home can be understood as firmly and unquestionably rooted to tribal territory. Aroha Harris (2007:54, 2009) explains how in the Māori world, home - that is, in the papa kāinga - is romanticised, comfortable and relaxed; it is culturally, demographically and tribally specific. Home is constant and has the "power to call on its people, no matter where their

90 Whakapapa kōrero are narratives referenced to layers of occupation, and stress relationships between people and tīpuna (Smith 2007:276).

91 Examples from my interviews will be given momentarily. 
lives take them" (Harris 2007:180). Yet, while home is tribally-rooted, it is also specific to place(s) of personal development and residence. Harris (2007) confirms the dynamism of home for Māori. Working with the experiences of Ngā Puhi in Auckland in the postworld war period from 1945 to 1967, she notes that home can expand beyond essential tribalism and yet remain tribally-grounded $(2007: 25,2009)$. Harris identifies this as a shift between old, inherited and new, adopted notions of home through experiences of migration. Similar to Hall (1995), she locates home as travelling in space, being "robust enough to transcend geographic boundaries" (Harris 2007:180).

Harris highlights the relationships between tribal-home and the city, tradition and modernity and their lived connections, rather than their apparent disparateness (2007:181). She speaks of Ngā Puhi in Auckland who, in their attempts to maintain links with home, create something communally familiar that is like being back-home. They lay their roots down in Auckland city while still retaining links to Ngā Puhi homelands so that home does not stop being influenced by home members even though they no longer live there (Harris 2009). For iwi-Māori living outside their papa kāinga (especially if this is for multiple generations), the idea of home has changed. Carter explains, "Many now have a historical connection to the new environment and think only of original home in an abstract way. They resemble the hau kāinga groups culturally and spiritually, but do not necessarily desire to participate politically or economically with them" (2006:43). In this sense, home can be seen as transferred (extended) and created (expanded) in the diaspora. It is related to the idea of divergent, interacting and connected tūrangawaewae as "the particularities of specific homes [merge] and [interact] with other homes" (Harris 2007:180).

\footnotetext{
92 My aim is not to treat tūrangawaewae as a synonym for home. Although the concept of home may be similar in meaning in some respects to that of tūrangawaewae and may be used inter-changeably by my interviewees and by others, both terms are still linguistically and ontologically different and should be treated, respectively, as such. With that said, linguistic interventions can be made to clarify the specificities of home which differentiate it from other kinds of home. Consequently, home can be used, in some instances, as a metonymic form of tūrangawaewae. These possibilities will be explored shortly.
} 


\section{From Places to Paths}

\section{i. Exploring the Dichotomy of Spatial Roots and Routes}

Much theory on diaspora has developed by dichotomising place roots with spatial routes, assuming an either/or condition. Hall $(1990,1995)$ distinguishes between the state of roots and the state of routes through the discourse of 'closed' and 'open' diasporas ${ }^{93}$. Through this logic, the cultural identity of the 'closed' diasporic - seen in this sense as being rooted - is guarded, nurtured and activated imaginatively in a specific location perceived to be a physical and enduring representation of one's cultural essence. One's cultural identity in turn is 'authenticated' through the relationship with his/her place roots - a relationship which preserves the roots-as-centre in order to sustain the cultural continuity believed to derive from it. The spaces outside of one's original home thus become peripheral to one's cultural identity. The 'open' diasporic, on the other hand, is one who has been routed with no particular one-true-home since $\mathrm{s} / \mathrm{he}$ is culturally influenced by an array of multiple places. The routed diasporic dwells in the 'non-rooted' locality of diaspora, amongst and in-between a plenitude of transient and optional homes, evoked at different times in the life journey. Through the language of Hall's 'closed' and 'open' diasporas, one is literally and figuratively rooted to the homeland or routed in the diaspora.

As some studies of diaspora juxtapose cultural roots with diasporic routes, studies in Geography, as well as some anthropological and sociological approaches to spatial identity and mobility, do the same for concepts of place and space. Place and space can be approached in a variety of ways, each producing different sets of meanings which, as always, are contextually dependent and interpretively influenced. For instance, space can be perceived of in a Cartesian fashion (Kirby 2009:5) as a void to be filled, occupied or 'cancelled-out' by place. Place can be interpreted as a "Newtonion container" (Buttimer 1980:160) of "distinct coherence" (Massey 1999:14), one that is well-defined and largely inward-looking. In this sense, space and place are oxymoronically paired (Ingold 2009:32). When fitted with Diaspora theory, space and place can be juxtaposed against each other, making place associated with roots - seen as introverted and bounded by strict borders; whilst space is associated with the diasporic idea of routes, as outward-looking,

93 See Chapter Three for further elaboration on 'closed' and 'open' diasporas. 
extroverted, and located over "horizons of reach" (Buttimer 1980:170). James Clifford (1994:310) asserts that autochthonous tribes themselves are grounded in specific locations through a sense of rootedness to place, whereas diasporics simply are not. This echoes what Clifford describes as a "tribal-diasporic" (1994:310) predicament where the 'global' domain of diasporic space is defined against the borders of autochthonous claims to place made by Indigenous groups.

Clifford's contention of the concepts of 'tribe' and 'diaspora' married with Hall's use of diacritically positioning 'roots' and 'routes' demonstrate the restrictions inherent in the limited exclusivity of either/or binaries which can work against Indigenous peoples. Carter identifies these spatial limitations as the "problem of place" (2006:35), and Appadurai (1988:37) explains how place can be used to differentiate and exclude 'the native' from the distant metropolitan West $^{94}$. He refers to place, in this sense, as a "metonymic prison" (Appadurai 1988:40) that incarcerates natives, mainly to 'the land'. Indigenous peoples are generally engaged with accordingly and are constructed through the Western imaginary of 'native geographies' that are to go undisturbed by time and which are to remain culturally pure and isolated from the impact of non-local others. Obviously, such a construction contradicts the imposition of colonial agendas upon Indigenous peoples and their territories worldwide, not to mention the consequential interaction and influence of colonial and non-colonial cultures upon Indigenous communities and traditional places. In addition, Eurocentric constructions of "native place' can conflict with ancient and contemporary forms of "tribal cosmopolitanism" (Clifford 1994:310) - forms which imply that the tribal-diasporic tension is not absolute (however, the pairing should still be subject to scrutiny and its use justified by the context). But, just as we need to be critical and clear in uniting ideas of tribe with ideas of diaspora (Clifford 2007), we also need to be weary of isolating and dichotomising them (Clifford 1994) into completely separate and ontologically distinct spheres of habitation that do not account for those who may indeed inhabit both 'sides' comfortably.

Similar to the limitations produced by binarily opposing 'tribe' and 'diaspora', exclusivist spatial distinctions perpetuate assumptions that, in the Kahungunu case, only

94 The terms 'West' and 'Western' can be ambiguous as they "represent very complex ideas and have no simple or single meaning" (Hall 2002:56). In this thesis, however, they are largely used as a gloss for the coloniser - typically, the dominating culture. 
allow the subject to ontologically inhabit the space of either Kahungunu or Wellington. The either/or binary of choosing 'tribe' or 'diaspora', 'roots' or 'routes' to describe the Kahungunu experience in Wellington is counter-factual at least and counter-productive at worst to the reality of Kahungunu forms-of-becoming across human relations and spatial dimensions. These binaries can be used to re-produce the same assumptions made by colonial-logic that misarticulate the Indigenous person as quintessentially fixed to particular places of imagined cultural coherence. In this sense, place roots are supposed to be part of the ontological syntax of the Indigenous person, and without or outside of these roots the Indigenous person is seen as incoherent to the Western imagination. To the contrary, the diversity of Māori lives means that they are not culturally or physically bound to one particular place per se.

Kahungunu are 'unfinished' and continuously 'becoming' in many kinds of spaces and places without necessarily producing a "dissonant narrative" (Massey 1999:14). This is not to imply that place roots have no validity in the Kahungunu story - which would be erroneous, insulting and damaging to Kahungunu, especially in light of their rightful claims to politically control ancestral lands, resources and assets. What it is meant to imply, however, is that the spatial articulation of Kahungunutanga is incomplete without the inclusion of its members' contemporary routed journeys, which are important and often overlooked or dismissed in the living tribal biography. Moreover, as Castree points out, the problem is not always necessarily with these types of dichotomies, but instead with who has the right to construct and perpetuate them. He says:

"Rather than asking whose geographical imaginations are 'correct', we need instead to ask: who has the power to construct what geographical imaginations and with what effects? It encourages those whose geographical imaginations are dominant, emergent or subordinate... to actively justify the kind of world those imaginations are designed to create" (Castree 2004:139).

\section{ii. Exploring the Intersection of Spatial Roots and Routes}

Instead of dichotomising roots/routes, place/space, tribe/diaspora, perhaps it is more useful to understand how my interviewees experience spatial movement and the relations between differing places. Kin connections across different places, express a type of translocalism that help unify Kahungunu in a diversity of places, namely those on tribal 
grounds and those in the diaspora. Castree (2004) uses the context of the global Indigenous movement and its internationalisation of autochthonous rights and local ownership of resources to address the inter-dependencies of (people in) places and the strength derived from their translocal connections. He notes how Indigenous peoples worldwide are uniting and collaborating in the name of protecting their rights to selfdetermination and control over their ancestral domains. Castree speaks to 'critical geographers ${ }^{95}$ who are narrowly sceptical of inward-looking place-making projects that they see as rejecting the non-local, 'global other'. They refer to these projects as examples of kinds of socio-geographic essentialism: "militant particularism" (Williams 1989:249), 'geographic fetishisation' (Watts 1999:92) and "geographic apartheid"96 (Castree 2004:135). Castree argues, however, that although Indigenous projects may be essentially place-making they are not completely place-bound. In the context of Indigenous peoples who need to defend their right-to-place now more than ever, many are establishing translocal links with other Indigenous groups in order to give collective power to their shared voices, interests and agendas. Castree states:

“Attempts to put 'strong' boundaries around places - that is to enclose peoples, resources or knowledges within a 'local' domain - are invariably misguided because such boundary acts are always false attempts to shut-out (or at least ameliorate the impacts of) translocal ties that in part constitute those places. They are, in other words, a denial of a fundamental ontological fact of our time; namely, that the global is in the local" (2004:135; emphasis in original).

He demonstrates through global indigenism how one can indeed support a politics of (local) place without reverting to Newtonion-like imaginaries. The cosmopolitan character of Indigenous translocalism "embraces place interdependency while defending local specificities" (Castree 2004:158). In the Wellington context of Kahungunu, placebased imaginaries need not be in opposition or conflict with their peoples' global tendencies or diasporic routes since they need each other to work fully and properly for the whole tribe. Ideas and experiences of home, for some Kahungunu in Wellington need

95 Although Castree does not define critical geographers, he uses the term broadly to imply left-leaning schools of thought within Geography, such as Marxism, feminism, anti-racism.

96 While Castree is supportive of certain place-making projects, he still questions and is critical of their potentially exclusionary consequences for non-Indigenous peoples (2004:135). 
not be wholly "“introverted' or 'extroverted' but can be both simultaneously and with a variety of local and extra-local consequences" (Castree 2004:150).

Translocal approaches reflect relational processes of 'entangled similarity and difference' (Clifford 1994:310) within entangled places. Giddeons states, "What structures [a] locale is not simply that which is present on the scene; the 'visible form' of the locale conceals the distanciated relations which determine its nature" (1990:19; my emphasis). Places outside of Kahungunu tūrangawaewae are, for my interviewees, "articulated moments in networks" (Massey 1994:5). They are networks defined by movement not necessarily to place for its own sake, but to family, friends, work prospects, travel and endeavours of self-exploration that may lie beyond tribal domains. Ingold (2009) seeks to clarify relational approaches to place by differentiating between the ideas of 'networks of transport' and 'meshworks of wayfaring'. He reasons that "lives are led not inside places but through, around, to and from them, from and to places elsewhere" (2009:33), along paths which entwine trails of encountered persons, binding the life of one to the other. Ingold describes this process as "wayfaring" (2009:33) and explains the constitution of the meshwork as a "binding together of lines, not [a] connecting of points" (2009:38). As such, place is defined not by its containment and bordering but by the mobility of its inhabitants' journeying and their bonds formed with people in other places.

Lilomaiava-Doktor (2009) applies Samoan concepts of spatial mobility to the experiences of Samoans moving to and from Samoa, New Zealand and the United States. She challenges Western notions of space that attempt to 'contain' Samoan people in dichotomist zones of urban/rural or village/metropolitan. Through the Samoan concepts of space (vä) and movement (malaga), Lilomaiava-Doktor demonstrates how it is "social connections rather than geographic boundaries that are central to Samoan conceptions of movement. In movement, the philosophy of $v \ddot{a}$, the 'in between space,' relates and connects people irrespective of geographic and residential locations" (2009:21). In a Samoan context, positioning 'roots' and 'routes' as contradictory is false. She maintains that Samoan identity and belongingness are personified in kin connections and are articulated through social relations across space, rather than through methods of 'incarceration' to place. Lilomaiava-Doktor suggests that we re-imagine and re-articulate 
space and the people in them through their own cultural metaphors, stories and practices. Through her example of using Samoan cultural metaphors, we can learn to transcend the limited language of geographic boundaries that divide and isolate Indigenous peoples from the world they are very much a part of and help create. The language of placemaking and of spatial boundaries can be only partial examples available in the arsenal of spatial discourse, adding to it ideas, concepts and experiences that instead of always separating, most of the time, just relate.

\section{Whakapapa (Part One)}

Raymond Young urges the use of "local cultural metaphors [that] expand and redefine people's relationships with one another as they move" (1998:i). The Māori concept of whakapapa is ideal in capturing and explaining the inter-relatedness and interconnectedness of people, places and things across space as it is a tool that arranges and governs relations within and between them. Whakapapa is used to imply genealogy, yet it means to lie flat and place in layers, one upon another (Roberts 2006:4), as well as meaning, the creation of layers, and layers of interconnection (Smith 2007:276). While it is popularly understood as a way to trace and order peoples' ancestry, Roberts states:

"Everything in the universe has a whakapapa; people, animals, mountains, lakes and rivers - the environment. Understanding whakapapa from this perspective is fundamental to understanding how Māori view the world and their relationship to others. Everything and everybody has a genealogical link that inter-connects and inter-relates to each other" (Roberts 2006:4; my emphasis).

In matauranga Māori, whakapapa is the major ordering principle of the world. But not only does it conjoin and order seemingly separate, disparate elements, it laterally determines their bond through a dimensional web of layers. Carter (2003:32) identifies three major categorical worlds of whakapapa: whakapapa atuatanga (genealogy of the spiritual world), whakapapa pūtaiao (genealogy of the natural world), and whakapapa tippuna (genealogy of the ancestral world). She says, "These worlds continuously revolve and interact and give whakapapa its dynamic nature... [as] whakapapa prescribes a formal sequence of events that helps in the understanding of how things work and gives 
everything its place in the world" (2003:32). Whakapapa tipuna is relevant for explaining translocal iwi connections and communities across space.

\section{i. Whakapapa tīpuna}

Similar to the way in which the Samoan concepts $v \ddot{a}$ and malaga explain individual and group connectedness despite geographic location, whakapapa can do the same in a Māori context. Whakapapa binds people to each other, weaving dependencies that form expansive networks and 'meshworks' of solidarities across time and space. Whakapapa tīpuna complements and supports these relationships and interdependencies between kin dwelling in places in, near, and far beyond the hau kāinga, binding them as a result, to a shared collective future. Whakapapa is about belonging since it legitimates "the spiritual and political obligations afforded to each individual through birth" (Roberts 2006:4). Although Kahungunu members may live differently and remotely from the hau kāinga communities, they are nonetheless extensions of those communities, and so may be obligated to represent and service them when and where necessary. However, the types of service and the ways in which they are to be carried out are perhaps largely dependent upon the individual and what s/he can offer.

\section{$\underline{\text { ii. Te Wheke }}^{97}$}

Te wheke, or the octopus, is a creature which sustains itself by reaching out its tentacles to draw food in, and can be used as a symbol for a collective tribal body that lives by drawing and feeding on the knowledge and contributions of its members, represented in its extended arms. On the octopus,

"Each tentacle represents a dimension that requires and needs certain things to help give sustenance to the whole... The tentacles move out in an infinite direction for sustenance when the octopus moves laterally. The tentacles can also intertwine so that there is a mergence, with no clear cut boundaries. [However,] the dimensions need to be understood in relation to each other, and within the context of the whole" (Pere 1991:3).

Carter (2006) uses te wheke as a symbol of tribal unity, intra-dependency and survival. Te wheke, like the tribe, is an organism that survives on constant internal acts of reciprocity,

97 Te wheke is an important figure and symbol in Māori oral traditions. One example where it is used is in the story of the ancient Māori ancestor Kupe and his discovery of Aotearoa by hunting and following an octopus to its shores (Carter 2006:40-41). 
each part of its body fulfilling a role and its conjoined obligations to ensure the health of the whole system. For example, some of te wheke's extended tentacles can represent Kahungunu people and communities dwelling outside the ancestral home - home being the heart. Tribal identity is still sustained and sometimes strengthened beyond tribal borders. The value of the wheke metaphor in the context of this research is that regardless of the fact that Kahungunu dwell in Wellington, they can still contribute to their iwi in important and varied ways.

Carter uses a wheke-inspired model to "ensure more inclusive participation" (2006:40) of Ngāi Tahu in Auckland within their hau kāinga and with their tribe - a model she calls Te Wheke. She provides a framework in the Wheke model, building on the whakapapa principle and outlining criteria for the full participation and representation of tribal members, regardless of their location. For instance, the concept of whanaungatanga is an important element within Māori society and for Te Wheke. Whanaungatanga is concerned with maintaining open, positive relationships and strong connections with ones kin group. "Whanuangatanga speaks to the inter-relatedness and oneness of all things. It reinforces both the commitment and responsibility whānau members have to each other" (Roberts 2006:6). Manaakitanga is another pivotal aspect of Te Wheke and of maintaining the health of a whakapapa-based network. If whanaungatanga is about maintaining relationships, then manaakitanga is about how they are maintained. It is concerned with "how the iwi members practice upholding the responsibilities and obligations between all the members of the iwi... [It] ensures that everyone is included in various ways" (Carter 2006:42). By upholding one's responsibilities to the group, one's mana is made "visible, influential and far reaching" (Roberts 2006:14). Kaitiakitanga, or care of and guardianship over ancestral land for present and future generations, is another aspect with which Carter associates enacting whakapapa responsibilities (2006:42). Whanaungatanga, manaakitanga and kaitiakitanga are all elements in which my Kahungunu interviewees exercise and strengthen translocal ties to their Kahungunu tīpuna, whanaunga, tūrangawaewae and iwi, at home, in Wellington and beyond. 


\section{iii. Whakapapa of Experience}

Aroha Harris conjures the concept of "whakapapa of experience" $(2007: 25-26,2009)$ to speak about interconnected layers in the Māori world that are "more than the whakapapa of blood and bones" (Harris 2007:25), but include the social experiences between members of shared descent. Harris' use of whakapapa of experience can help bring us beyond spatial binaries as it uses whakapapa to include and order constitutive experiential parts of a laced social whole. She clarifies that whakapapa of experience is not to change or compromise whakapapa tipuna, as her aim is to use the former to complement the latter and to accommodate for the experience of inter-rohe movement of Ngā Puhi to Auckland. Indeed, the experiences of Kahungunu in Wellington can add to their tribe's whakapapa of experience, too.

Harris does insist, however, that whakapapa of experience not exist on its own or apart from tribal whakapapa. She states, "Whakapapa of experience can only be overlaid onto tribal whakapapa - tribe permitting - it is not whakapapa itself and never will be. It cannot replace whakapapa, it cannot even shift it, although it can add texture and colour" (Harris 2007:26). While Harris' whakapapa of experience is well conceived of, her approach necessitates ties to tribal whakapapa which can possibly produce limiting results to a project that seeks inclusionary frameworks in discussions on belongingness to place. Although Harris invalidates separating whakapapa of experience from tribal whakapapa, perhaps it would do some good to engage whakapapa of experience on its own terms. The experiences of belonging to Wellington for some Kahungunu - which will be explored shortly - demonstrate the presence and relevance of a concept like whakapapa of experience, without necessarily claiming, highlighting or privileging whakapapa tīpuna in the process.

\section{The Language of Home}

"I think we're just in Wellington waiting to go home. And the time will come... the career options will change, there might be schooling options that we'd want or there might be other influences that take us back... even me, I'm waiting to go back home." 
If the previous statement endorses any kind of generally shared truth, what is the 'waiting period' in the lives of expatriate and diasporic Kahungunu currently residing in Wellington? Is living in Wellington merely a period of 'incubation' where desires and pursuits to 'go back home' marinate daily in one's emotional and mental portfolio? What does this waiting period do to ideas and experiences of home? Is home recreated or is it constructed anew in Wellington? Does home for Wellington-dwelling Kahungunu become uni-locational for those caught-up in the idea, memory and longing for backhome, and multi-locational for others who travel physically and emotionally between many homes? The answers to these questions are non-uniform, subjective and dependent on the realities and opinions of individual Kahungunu in Wellington. Nonetheless, some broad themes concerning experiences of home were extrapolated from my interviews and will be explored in this section so that statements can be made, and the opening quote explained, complemented and challenged.

\section{i. Terminological Sensitivity and Locational Specificity of Home}

To speak about something so familiar and common as home can prove to be difficult when trying to unravel, determine and emphasise its semantic layers. Most of my interviewees spoke of home in an intuitive, matter-of-fact way, echoing what Harris (2007:179, 2009) has described as, home being so familiar in the Māori world that it requires no explanation. At the same time of speaking of home in a definitive, nonexplanatory way, my interviewees would also describe themselves as belonging to or being influenced by different places, and would speak about home as if it was situated in multiple locations at once. This may imply that first, home is contextually-oriented, and second, the idea of home in a diasporic setting is not necessarily a singular notion of 'tribal place'. Although it is familiar and a given for most, home was many times summoned and described in specific ways, distinguishing one (kind of) home from another. For example, interviewees who were raised near their tribal marae, when outside of it, would sometimes say 'back-home' or 'home-home' to differentiate it from other places lived. Cellia explained:

"Home is in Wairoa but I currently live in Porirua... I always say 'back home' and that's the difference... But it took a while for me to call Porirua or Wellington 
home... Before I used to say I'm going back to Porirua, or I'm going back to Mt. Vic... I never called it home."

\section{Cellia}

Cellia uses home in terminologically specific ways to contrast between, what for her is, her real, permanent home in Wairoa from what is currently an adopted, temporary abode in the township of Porirua, Wellington. Over time, parts of Wellington have become a peculiar type of home by domicile for Cellia. Yet, as a result of Porirua having become an additional home in her spatial network, Cellia is careful and specific when speaking about it as home, since it is not to be confused with Wairoa which holds a more profound meaning and connection to her. 'Back-home' denotes the place where she is of and from originally, and she continues to vernacularly identify with it as such. In this way, the language of 'back-home' and 'home-home' can be metonymic examples of ancestral tūrangawaewae.

In a separate interview, Lisa's experience adds to the clear, but subtle use of language in diasporic Māori differentiations and interpretations of home:

[Interviewer: Would you identify it (Wellington) as your home?]

"Yeah. Not home-home. But my home."

Lisa

[Interviewer: What's the difference?]

"Your home-home is where you're from and your home is where you live. Yeah. So I'm not from Wellington. And I'm not from Paraparaumu or Porirua. But I live there. I'm from Kahungunu and Rongomaiwahine."

Later in the interview, Lisa expressed:

"Home-home for me is in Māhia."

According to Lisa, there are interpretive layers to home, as her use of 'home-home' may produce a different set of meanings and values from her use of 'home'. Even though she was born and raised in Wellington, she identifies it as a home by residence, implying a partial sense of connection and belonging. Her place of complete integration and utter belonging is in the home that she is of, in Māhia. It is important to note that Lisa, who 
was born and raised in Wellington, and Cellia, who grew up on Kahungunu territory feel very similar in regards to their connections to their tribal land, and in how they use parallel language and meanings to reflect the distinctions of home and belongingness to it. In short, the use of 'home-home' and 'back-home' express the idea of spatial roots legitimated by whakapapa of kin. Whereas, the broader, non-definitive 'home' can denote merely a route in one's spatial journey to, from, through, across and within place(s), legitimated by whakapapa of experience. Yet, just as routed homes can prove to be many and layered, so too can rooted homes.

In the case of Te Hiwi, a rooted home for him is dictated by where he traces his whakapapa, where he grew up, where he lives, and where his immediate family is, demonstrating a multi-vocal and multi-locational nature of home. Although Te Hiwi uses 'home' to express belonging to varying spatial and social contexts, how he employs it reveals its layered complexity and dynamism. Te Hiwi articulated the layers of home in his life:

"[Home is] Hastings and Mohaka 'cause Hastings is where I went to College and went to school and that's where my grandmother lives and Mohaka is where my bones are from, where my urupā are."

Te Hiwi

Although Te Hiwi has roots in Mohaka, he is not rooted only to it. His experiences and whānau links in Hastings have meant him 'planting' or finding roots there too, and claiming it as home. Thus, in claiming a place as home, experiences in place are different but still significant as experiences of place.

For some interviewees, home is not located only in the place of one's ancestral tūrangawaewae, but is located more generally, as well, within the space of Kahungunu rohe. For example, although Hastings is not Te Hiwi's ancestral tūrangawaewae, it is a place that still lies within the iwi bounds, and is thus, culturally familiar and comfortable enough so as to render it a home. He stated:

"Hastings... that's what I call home even though where I'm originally from is like a two-hour drive. But Hastings is close enough. It's on the Kahungunu side."

Te Hiwi 
Home reaches beyond the tribal marae, and for some Kahungunu becomes broader and stylised. Te Hiwi demonstrates how home need not only be focalised to particular ancestral places, but can encompass places within the larger tribal district.

On the other hand, Jorgette notes that geographically, Kahungunu territory is too spread out, vast and portioned to get the feeling of home being anywhere and everywhere across the rohe. She stated:

"You don't get this feeling of Ka-hu-ngu-nu or you can't go to one place and go: 'This is Kahungunu'. You go to one place and you go, 'This is Takapou'. You go to one place and you go... 'This is the Takitimu Festival' or 'This is Hastings'. You don't go to one place and go... 'Ngāti Kahungunu'. Whereas, I think you can go up Gisborne way and everyone [goes:], 'Ngāti Pōrou'... [But, with] Kahungunu... it's all split up."

Jorgette

When in Kahungunu territory, Jorgette does not feel reminded of being within a Kahungunu domain, nor does she broadly connect with it semiotically as a Kahungunuhome. Because of the strong cultural and historic hapū identities within Kahungunu and the geographic divides between them, further emphasised by a state highway being constructed across the middle of Kahungunu rohe, Jorgette situates Kahungunu identity and home as definitely more specific to particular places within the rohe. Perhaps Te Hiwi's identification of Hastings being 'close enough' to Mohaka implies, not necessarily that Hastings is home because it is on Kahungunu rohe, but that it is home due to him having lived there, his grandmother who lives there now, and because Hastings is culturally, socially and geographically 'close enough' to his home-home.

Home is expressed through further layers of entanglement outside of Kahungunu territory. Te Hiwi was raised mostly in Wainuiomata in Wellington and currently ${ }^{98}$ resides in Upper Hutt with his family; he lives daily travelling to and from Wellington city. For him, Wainuiomata, Upper Hutt and Wellington city are kinds of home too, and he does not make a stark distinction, through language at least, between home as place of tribal

98 'Currently' is used to imply, at the time of interview. 
identity and home as place of habitation and experience - although such does not imply that there are no semantic differences between them ${ }^{99}$. Te Hiwi expressed:

"When I'm in Hastings I'm like, 'This is home away from home.' But when I come back to Wellington it's like, 'I'm home away from home'... Hawke's Bay and Wellington are always home away from home for my family."

Te Hiwi

Home for Te Hiwi is where his family lives. Thus, both Hastings and Wellington in general are home for him, but in evidently different ways from Mohaka, as they are places that have 'earned' the title of home through his own and his family's lived experiences there and through ongoing familial ties and social relations to those places.

\section{ii. Power and Implications of Naming: Wellington and Te Whanganui-a-Tara}

Dimensions of space for Kahungunu in Wellington are further investigated and clarified in this section. This is done through the use of Māori cultural concepts of space and their philosophical tools that regulate relations to it. In a tribal-diasporic context (at least), there appear to be two overlapping paradigms of geographic space that inform "how people 'read', 'see' and understand their relationship with the landscape" (Carter 2005:7): the paradigm of officialdom and the paradigm of Māoridom ${ }^{100}$. For instance, to claim a Wellingtonian identity is to voice a sense of belongingness to the cultural and geographic spaces delineated by officialdom. Whereas, to lay claim to being tangata whenua or mana whenua of the same area might deem one to belong to the landscape in a way that is specific to Māori interpretations of spatial belonging ${ }^{101}$. Carter affirms, "The way we talk about the landscape depends on how each group understands the landscape and what is important to their particular relationship with it" (2005:16). Spatial 'reading' and belongingness are quite distinct between officialdom and Māoridom. Yet, their relevance in the lives of my interviewees shows that Aotearoa/New Zealand and the

99 While Te Hiwi was not specific with terminology of home in his interview, at least not in the same specific way that Lisa and Cellia were, it does not mean that he does not understand there to be differences between different spatial homes. It can be simply that the ways in which he expresses home and where it is located depends upon the context and on his audience.

100 Carter (2005) identifies these cultural paradigms of space as distinct environmental languages. She notes how language can be used to map a physical space, and how it illustrates the ways that space is culturally perceived and engaged with.

101 Wellington would be the consequence of claiming and naming place through the discourse of officialdom; whereas, Te Whanganui-a-Tara or Te Upoko-o-te-Ika-a-Maui are the names for parts of the same area, as determined by Māori history, custom and environmental literacy. 
places within it cannot be interpreted uni-spatially as devoid of difference. In this research, Māori cultural and epistemological elements are included in the conversation of spatial literacy and belongingness to further dissect the layered meanings of home.

In a Māori spatial paradigm, the tangata whenua-manuhiri relationship is essential. My interviewees who do not whakapapa to the tribes of the Wellington region understand that they are not tangata whenua in a local, tribal sense - in other words, they lack ahi kā (roa) in the area. Yet, those who identify Wellington as a kind of home may still summon the tangata whenua concept to describe their relationship and association to the area. For instance, Jamee stated:

"Well I think I am tangata whenua "cause I was raised down here."

\section{Jamee}

Jamee claims an identity as tangata whenua that is not based on whakapapa tīpuna, but on whakapapa of experience. Because Wellington is his home, he feels himself to be a local of that world. Jamee is tangata whenua because he lives and is from, on one level, Wellington. He does not claim to be tangata whenua in a tribal sense though - that is, as Te Ati Awa, Ngāti Toa or Ngāti Raukawa. In saying he is tangata whenua of Wellington, perhaps Jamee identifies himself as a naturalised local of that space, but through the use of cultural concepts that are familiar to him ${ }^{102 .}$ A diasporic Kahungunu experience, such as Jamee's, requires one to navigate between two different spatial paradigms, but it also implies possibly changing some meanings embedded within them. Jamee's experience of home in Wellington exemplifies how some Kahungunu in Wellington are in the living process of re-interpreting Māori and mainstream 'norms' of spatial belonging.

Although Wellington, today, is not part of Kahungunu territory, a few interviewees acknowledged it as once belonging to Kahungunu rohe. Tamati explained:

"Te Ati Awa, Ngāti Toa, Ngāti Raukawa are only the latest iwi to be here. Wellington was like Auckland, it was a bloody highway in the day that people came. They may have settled here for a few generations and moved on... Kahungunu used to be here. This used to be Kahungunu rohe, so in that sense for

102 Perhaps the idea from the Taranaki word, 'ruranga' or 'guest', is useful here (and maybe in some cases, more so than 'manuhiri') because being a guest does not imply a timeframe by which one must necessarily leave, and it does not threaten local tangata whenua authority (Maaka 1994:328). 
me I have not left."

Wellington, or more appropriately, Te Whanganui-a-Tara, can be interpreted in a variety of ways that are not always strictly guided by Māori customary rules, since Tamati implies that he is not necessarily manuhiri in the land of Tara because his tribe has roots there as well. Te Whanganui-a-Tara can be viewed as a sort of home for some Kahungunu in Wellington because it belongs to the layered and connected place history of some Kahungunu tribes ${ }^{103}$. Thus, it was and continues to be a spatial root/route in the tribal biography of Kahungunu.

\section{Home in Diasporic Place}

What does it mean to be a Wellingtonian for my Kahungunu interviewees? Do they associate 'Wellingtonian' to a Wellington-dwelling individual, or to someone who claims Wellington as a home (base)? Is 'Wellingtonian' a type of identity where the spatial environment and culture mark the individual, or is it simply a semantic sign of locatedness? Does claiming Wellington as a home for some Kahungunu conflict with it as the home-home of other, local tribes? Or, is being Wellingtonian to be understood through a different kind of paradigmatic lens? Whether Wellington is seen as an adopted or naturalised home, or as temporal, peripheral or contextual, many interviewees described themselves as Wellingtonian, and each for a variety of reasons.

\section{i. Dimensions of Wellington as Home}

\section{A) Domiciliary:}

For some Kahungunu, a Wellingtonian identity is claimed because it reflects one's place of residence. Wellington is peripheral, superficial and a temporal abode compared to the home back on one's marae, especially for those who did not grow up in Wellington. Tamati explained:

"I'm a Wellingtonian because this is where my livelihood is. I don't choose to live here... [W]hy I'm here is because this is where the work is. This is where I can make an income to ensure my kids get a good education and in doing so have the opportunity to make choices in their life. That's all. And when that's done and

103 See Ballara (1990), Best (1919) and McEwen (1971). 
when they're there, I'm gone. We're back home, in a flash.”

Tamati

Many Kahungunu who moved from their rohe to Wellington, like Tamati, are waiting to 'go back home'. Although Wellington may be a temporary presence and experience in Tamati's life, it is also, as he points out, the place of his livelihood. Wellington is an identity in so far as it locates where he domiciles, works and the main location of his daily lived existence. But, because Tamati retains close emotional and social connections to back-home, and travels there frequently, he is unthreatened by a Wellingtonian identity since he expects to, one day, leave it behind.

B) Acclimatisation:

Other interviewees related to being Wellingtonian through experiences of familiarity with the city and region, and through having gained cultural fluency in its habits and ways of life. Cellia identified herself as being Wellingtonian because she has grown accustomed to the city:

"I'm Wellingtonian 'cause I could get around the city. I know how to catch the bus and the train and I know where places are. But... I'm a rural girl from Wairoa who lives in Wellington."

\section{Cellia}

She later added:

"When people ask where I'm from I always say from Wairoa, but I live in wherever - Porirua."

Cellia

In calling herself Wellingtonian, Cellia is careful that it does not overshadow her being from Wairoa, which is more of a defining spatial element for her. At the same time, her loyalty to home in Wairoa does not detract her from developing a relationship with Wellington, especially since Cellia has mastered Wellington's spatial and cultural characteristics.

Many interviewees spoke of the appeal of Wellington's cosmopolitan character and cultural diversity. Cellia lives in the township of Porirua, and feels comfortable there because of the heavy presence of Māori and Pacific Island communities. She stated: 
"There's [sic] lots of brown people and... lots of Islanders... And the other thing was I met a huge community from Kahungunu... who live up there, so that for me was, Yay!"

Cellia

Cellia's identity as Kahungunu ki Wairoa helps to customise her experience in Wellington by her choosing to surround herself with culturally similar people and with extended kin. Consequently, she replicates elements of back-home through her social connections with people in neighbourhoods composed of communities that are culturally akin to hers. Additionally, Cellia expressed loving Porirua and feeling a sense of solidarity with the people there because they are sensitive and attuned to Māori cultural practices, as well as familiar with experiences of migration.

C) $\underline{\text { Historical: }}$

Being Wellingtonian is not dependent only on experiences of domicile, and cultural acclimatisation and customisation, but also through a continuing historic relationship with the place as home. Jamee shared:

"I've always thought I belonged here... I am a part of this land here in Wellington... I've always known I sort of got the link with back-home, up in Nūhaka. But I also feel that I belong here [to Wellington] as well."

Jamee

Jamee's experience is largely reflective of second and third generation immigrants who make home in 'new' locations. His sense of belonging to Wellington comes from a history with the place, its people and culture that cannot be subtracted from the man he is (becoming). He continued:

"Wellingtonian? Well I've always described myself as being a Wellingtonian because I was born and bred here. Obviously with sports and stuff, going to other parts of the country, I say I'm Wellingtonian. And I've always said that ever since I was a kid... I've always expressed that I'm Wellingtonian to whoever I've spoken to."

Jamee

Jamee's declaration of being Wellingtonian comes from his belonging to Wellington in a socio-historical sense, since Wellington has been the primary setting of his life. It is a 
relationship to place that has shaped his reality and one that he proudly and continually identifies with.

D) Generational:

Another aspect to feeling like a Wellingtonian is by default, with Wellington being a home for one's children. Although many interviewees may be staying in Wellington for work, education and so forth, the raising of their children in Wellington becomes another reason to stay (longer). In making Wellington home for one's children, it becomes home or home-away-from-home for oneself. Challen explained:

"I don't know if I truly feel like a Wellingtonian because I wasn't born here... I don't whakapapa to this area, but... maybe when I had my daughter I felt more like a Wellingtonian because... she was born here and I attach myself to that sort of concept of feeling like a Wellingtonian. This is potentially at this stage her home, making it my home."

Challen

For Challen, feeling like a Wellingtonian comes through her child's experience with Wellington as home, since it is the place in which her daughter is currently maturing. Through Challen's desire to provide security, normalcy and grounding to place for her daughter, Challen may 'ground' herself to Wellington as well.

Although home for Jamee is Wellington, his wish to know his Kahungunu-home more intimately by living there is halted by the lives of his children who are growing up in Wellington. He stated:

"Where is home for me at the moment? Well it's still Wellington at the moment. It's still Wellington... because I still got my kids here and that sort of stuff."

Jamee Jamee's generational connection to Wellington is carried on in his children who live there. And so, like Challen, he has established those things for his family that 'ground' them to Wellington.

E) $\underline{\text { Civic: }}$

Since Wellington is a city many of my interviewees care about and feel a responsibility towards, civic connections to place are another aspect expressed by them in 
regards to identifying as Wellingtonian. Lisa expressed feeling responsibility towards Porirua and its residents, as it is a place that cared for her in her youth:

"I do have a real affinity with Porirua. Yeah. I don't know why. 'Cause we were brought up there when I was little... I have a connection to caring about the people there actually... Not on the same level [as with back-home], but just as a... reciprocity and thanks. Like, I'd do something for Porirua 'cause Porirua looked after me when I was little.”

Lisa

Lisa's affinity to Porirua demonstrates the localisation of her Wellingtonian identity. One way she claims a Wellingtonian identity, is by her emotional attachment to Porirua and by her civic responsibility to the people in and of the place. Her relationship to Porirua is one guided by respect, reciprocity and solidarity.

F) Emotional:

Other than being grounded to place, home also travels through space as it is invoked and directed by various sentimental states. Te Hiwi noted:

"[Home] being either Wellington, Hastings, either or, whichever my emotional state wants to go to."

Te Hiwi

Te Hiwi is emotionally tied to places outside his ancestral-home in Mohaka which have been written into his psyche. His experiences and those of Lisa, Cellia, AT, and others demonstrate that although some Kahungunu in Wellington may be there just 'waiting to go back home', for many, home, or incarnations of it, have been made elsewhere, in the meantime.

\section{ii. Home is in the People: Whanaungatanga and Translocalism}

Home is not only determined by acclimatisation to place, or by domiciliary, historical, generational, civic, emotional, as well as cultural, spiritual and ancestral ties to place, but is created and sustained through translocal social relations as well. Indeed, home can be said to be constituted of translocal ties between whanaunga in different places. AT explained how her active connections to home are conjoined with her relations to people in those places: 
"I go back [to Hastings] because my mum is still there...She's the reason...I go back as often as I can. Unfortunately I don't go back for any Kahungunu meetings...but I do hear about...different events that are going on up there and who's who and what's happening."

AT's ongoing social connection to her Hastings home is maintained currently and mostly through her relationship with her mother, who still resides there. But, the lack of AT's physical presence at home is not a barrier to her being or getting involved there, especially since her ahi kā (roa) is kept alive through the social links she maintains across space. In her visits to see her mother, she takes part in marae life and in the lives of the people back-home. AT's social connection to home is constituted not just theoretically by her whakapapa links to the place, but practically in the translocal connections she has to people who are still there.

For some Kahungunu who cannot go back home for whatever reason, they get involved with their Kahungunu heritage through a loose community of other diasporic Kahungunu. They 'go back home' imaginatively through their relationships with Kahungunu people in Wellington. Yet, for many of them, literally going home may be an uncomfortable, strange experience if they have been outside of their Kahungunu-home for many years, have been away for most, if not all of their lifetime, and for those who do not have much close family there. It may produce related feelings of alienation, guilt, anger and exclusion that many may seek to avoid by simply not going, or by going infrequently. Cellia shared:

[Interviewer: Do you think many (people from Wairoa in Porirua) still have a connection (with their tribal-home)?]

"No, no actually ... They'd only ever gone back for funeral and I thought that was sad, like when their grandparents died and stuff. But that was the urban, I guess, upbringing. And the no desire to go back - I don't know why. Probably 'cause they know nobody or they don't quite have the connection, or something."

Cellia Perhaps for some there is a lack of desire to go home, and perhaps for others going home poses great difficulties, whether financial, practical, social or emotional. However, it 
seems that a common thread that keeps some Kahungunu in Wellington connected to their Kahungunu-home is through whanaunga. Those who may lack family back-home may turn instead to those in Wellington who do have strong links there. For instance, some people, such as Cellia, may come to embody place identity as it travels with them and is expressed through them in their relationships with other Kahungunu. In this way, home is spoken of not only in a nostalgic manner, but in a way to seek knowledge and to learn about it, as well as perhaps to learn more about oneself. Cellia continued:

[Interviewer: Why do you think that those from Wairoa here (in Wellington) still gravitate to each other?]

"Because at the end of the day it's your whanaunga from Wairoa that are gonna take you home when you die. I think it's because they want to...know something about home and to know people from home is a start...I think it's about... [having] something in common. Your ancestry, your whakapapa is what you have in common."

Cellia

For Cellia who considers Wairoa home-home, she becomes a link, an embodied expression of Wairoa to Kahungunu in Wellington who may not or cannot go back-home (yet). Of the Kahungunu she does know in Wellington, there is a desire to know of home and to possibly be home. Some Kahungunu return or visit it imaginatively through those who already have active and concurrent connections.

Interviewees who have had a recent hunger to know more about their tribal roots get closer to satisfying that appetite via whanaunga in the Wellington diaspora. Lisa connects to her Kahungunu-home through the social realm of kin relationships which are in part, preliminary steps to her physical journey there. She explained:

"The interaction with my friends who are from the same tribe, I think that is more of a recent development, maybe in the last...six years - like an awakening. And the interaction, it's more of a social interaction. But then within the social interaction, we will talk about home, or what's happening at home, or...did you know such and such, something happened to someone, sometimes issues, or sometimes we'll talk a little bit about whakapapa and how we're linked. But then the most recent is when we went home. Yeah. We went home at New Years, and 
that was the start - 'cause I haven't been back for long...to try and make regular trips back-home...I mean, I've been back-home a few times before then."

Lisa's experience with her cultural and place roots demonstrate how in the diaspora, sometimes starting and maintaining social relationships are precursors to discovering and harbouring physical relationships with ancestral-home. Talking about home with her Kahungunu friends and family in Wellington and elsewhere outside of Kahungunu rohe prepared and assisted Lisa to return there and to nurture a multi-dimensional relationship with Kahungunu.

\section{Home in Kahungunu Place: Connections and Reconnections}

Connections to Kahungunu roots reflect an unbroken relationship validated mainly through whakapapa. Indeed, Carter states, "The function of whakapapa is to anchor groups to known landscapes, and to establish the ongoing basis from which tribal mana (authority and power), identity, and activity in the present can be validated by the past" (2006:34). The tribal mana, identity and activity of my interviewees are enacted, for many, by returning to their Kahungunu marae and place.

\section{i. Going Back-Home: It's for the Kids}

The desire to go back-home for some Kahungunu in Wellington is aided by the fact that they have children and want to expose them to the home culture of their parents and tippuna. Thus, maintaining connections to home is just as much for the next generation as it is about the parents, their nostalgia for home and the social responsibilities they feel towards it. Cellia stated:

"Bringing up [children in Wellington], yeah that's something that worries me about...our baby is he's...born in town, you know, he's lived his two years in town, so...he hasn't had my upbringing...I do worry about him being a bit townish."

Cellia

Projecting living the next decade at least in Wellington means that Cellia contemplates the kind of cultural identity and place identity her child will have and fears he will be somewhat disconnected from her home - and his - in Wairoa. Some interviewees 
expressed a pre-occupation with children knowing their Kahungunu-home, but also with being culturally influenced by it. This demonstrates that just because Kahungunu rohe is not too geographically and culturally distant from Wellington, as it would be in international contexts, it is still distant enough to cause concern that one's children will be 'different' from them. Tamati keeps his connections with home alive so that his children know where to go to when they are ready. He said:

“That's why I go home, to keep my ahi kā roa...Keep the fire burning, keep it burning so that my kids know where to come home to over time."

Tamati

Residing in the Wellington diaspora means the added responsibility of constantly reconnecting to ancestral place to keep the memory, knowledge and continuity of it as home alive throughout the generations, despite not living there.

Tending to impaired links with home and making connections to it for one's children are important ${ }^{104}$. Some Kahungunu in Wellington who did not grow up with a physical relationship to their ancestral tūrangawaewae felt disadvantaged, and it was an experience they hope does not replicate in their children's lives. Jamee expressed:

"I wanna make it a [sic] annual thing of going back once-a-year sort of thing. And take my kids back up there and show them where their koro grew up and where he went swimming and stuff...Yeah, I'm strategising to organise, make it a [sic] annual thing to go back-home, 'cause I wanna make those links with my marae... and the people back there."

Jamee

Jamee provides an example of reconnecting to one's marae despite one's parents previously cutting-off links to it. He demonstrates that connections to home may not be important in some generations, but may indeed re-surge and manifest in the lives of future generations seeking to re-connect. Maintaining generational continuity with backhome is important for Jamee. His link to his Kahungunu home is one that he wishes to see strengthen in time and carry over into the lives of his children and future descendants, no matter where they might be. This may imply that the re-connective thirst for home is

$104 \quad$ I do not mean to imply that connections to Kahungunu roots are only ever impaired or never broken and then mended. However, the experiences that my interviewees shared focused more upon the impairment of those links, rather than on them being broken. 
to be quenched in part by the desire to empower one's children with knowledge and experiences of home in Kahungunu.

\section{ii. Going Back-Home: When the Time is Right}

For some interviewees who were born and grew up outside of their ancestral-home in Kahungunu territory, going back-home was a rare feat or one that simply never eventuated until much later in life. Some interviewees were kept away from their Kahungunu roots as a result of parents or grandparents leaving home, producing a cumulative effect on their children. Consequently, they believe themselves to have been socio-culturally disadvantaged, and seek to resuscitate that relationship to their tribalhome in adulthood, when the circumstantial conditions in their life are ripe to make that connection. Jamee's experience attests:

"I went back up home to Nūhaka, where Dad's from - the first time I've been up there. I went up there earlier this year. And just being there and knowing that my father was brought up in this area, and it's the area of Kahungunu, area of Rongomaiwahine...It just gives me a sense of pride... [and of] mana."

Jamee

Jamee continued at another point in the interview:

"It was a lonely experience 'cause I wanted my Dad to be there, but he passed away last year...[S]o I took it on my on two feet to go back, and...investigate it, and...learn more about it...It's making a link... I met a cousin who lives up there, up where we're from, and I made that connection with him, and...I want to make more connections as well."

Jamee

For Jamee, the physical home of his father was a missing piece in the puzzle of his own cultural identity as Kahungunu and of his place identity in Kahungunu. The passing of his father was an incentive for him to reconnect his father to home, and in turn, to connect himself with the place and the people there as well. Going home for Jamee was just as much about bringing his father home, as it was about bringing himself there, too. It is a connection that could not be rushed, but that nonetheless has been made and is sought to be cultivated over time, and in spite of physical distance and past grievances. 
Other interviewees grew-up physically distant from their Kahungunu tūrangawaewae not because their parents intentionally kept them away from it, but because the course of much of the whānau life was led far beyond the tribal territory and posed practical difficulties in exposing their children directly to home. Jorgette was born and raised in Christchurch with little opportunity to go to her Kahungunu-home in Takapou. Yet, life's circumstances have now led her to slowly, but surely, find her way there. She expressed:

“[B]asically as my father's gotten more reconnected it's sort of had a knock-on effect of reconnecting the rest of us, probably more me because I live with my dad. And I'm probably of an age now where it sort of goes into my head a little bit more."

Jorgette

Connecting with Kahungunu place for Jorgette has been dependent upon the reconnective journeys of other family members, whose journeys get entangled with her own. She continued:

"Now that I know a little bit more of the history...I know where my grandparents lived, I know where their original house was... So, I do feel comfortable and I do feel like I'm from there [Takapou] which is good... [O]nly a few of them [whānau] live in Takapou. That's quite interesting how most of them just want to. They have this kind of nostalgic link, yet they don't live there. And really... would probably struggle to live there 'cause there's no work there... It's a good feeling being there... People have this wonderful, huge loyalty to Takapou which it seems to me has to do with their experiences there rather than what the actual place has."

Jorgette

Forming a lived connection with a physical relationship to Takapou has meant a semantic transition of home for Jorgette. Takapou has gone from being a theoretical home, to one that is tangible, multi-dimensional and full of family history that she can reference through the landscape and through the stories carried in it and by the people there.

Global or translocal experiences outside of one's tribal domain are necessary in order to appreciate home, as well as for the personal growth of tribal members. AT spoke of its importance in her own 'forming', and passes little judgment on those who dwell and 
spend much of their life in Wellington, or elsewhere outside of Kahungunu. She is secure in the fact that they will eventually return home, and return to contribute to the well-being of home. AT expressed:

"I left home because my father said to me, 'You need to go out and broaden your horizon.' ... so I was encouraged...to go outside of the village and I did...I guess personally for me... when I left home I didn’t really leave home... Within my heart that is home. I just physically have taken time out, you know, from... Kahungunu, from Rongomaiwahine. And I think for me that there will be a time when you'll always go back but...it has to be your time. And whether the 9,000 of us that live here in Wellington is [sic] rowing that waka, that's okay... because their marae, their hapū will always be with them; will always be in them. It will never leave them until they are ready to go home and do what they have to do. So even if they join other kapa haka groups and they interact with other tribes and marry into other tribal affiliations, their Kahungunutanga or their maraetanga or their hapūtanga will always be within them and one day they will go back. Or not necessarily them - it might be their children who will go back and find out about their Kahungunutanga... Each person living here has got their own journey and when they reach that time they will go home. To what, I don't know. They might go home to retire. They might go home to make a business. But they will always head back to where their grassroots are at some stage in their life. But it will never leave them."

AT described home as being not only embodied in place, but as being an emotional and spiritual state that the individual carries within. It is a belongingness that is perpetually there, regardless of one's awareness to the fact. She implies that the fires of home for the 'wandering' Kahungunu are housed within. It is a connection that lives on through the people. Thus, the relationship and association people have to place cannot be defined in narrow ways that condemn one to remain entrapped within spatial boundaries (of understanding). AT's experience is that routed journeys are needed just as much as rooted journeys. But, its order is of no importance, just that both types of paths are eventually walked and their lessons realised. 


\section{iii. Going Back-Home: Tūrangawaewae and Kaitiakitanga}

Some interviewees addressed the meaning of ahi kā (roa) and their role in assuring its survival into the future, despite physical distance from it. Jorgette confirmed:

"I think ahi kā is about...making sure that the tūrangawaewae exists...as well as okay and exists into the future for those who want to...identify with that place and also look after it and give to it...[Y]ou can't expect to take anything from your tūrangawaewae apart from knowledge that that's where you come from. You can't expect too much from it if you don't give anything to it...It's literally where you stand...I think standing on it, knowing it and making sure that you're contributing to it is what that's all about."

Jorgette

Within Jorgette's perception of ahi kā (roa) is the idea of reciprocity. Although one can claim a tūrangawaewae without knowing it personally, as Jorgette states, one cannot expect much from it at the same time without giving to it and caring for it as it is a relationship sustained through acts of exchange for mutual benefit and survival. Similar to Carter's identification of kaitiakitanga, one's relationship with ancestral tūrangawaewae is characterised by responsibilities to ensure the health, continuity and growth of one's tribal home base. Although one may not physically dwell upon or frequently visit one's ancestral-home, it is a relationship that exists beyond physical grounds, but whose quality and well-being is dictated by acts of giving to it nonetheless, where it stands. Jorgette continued:

"[T]he way I see my tūrangawaewae is it's just there and I can always just go back there...I'm at this stage in my life where I have to know it and I have to know that it's doing well and that it's protected...so that it remains there, but I don't actually have to always be on it."

Jorgette

Physical distance does not necessarily equate to emotional and social disconnectivity or permanent disruption in the relationship with one's ancestral tūrangawaewae. Jorgette is concerned with knowing of, claiming and caring for her tūrangawaewae, but without her permanent physical presence upon it. 
For those who do not know their tūrangawaewae personally, encountering it for the first time may conjure dilemmas in regards to roles and appropriate behaviour. Jamee stated:

"Just like when I went back up home at the beginning of this year to my marae there, and I thought, 'Oh, Jeez, do I get welcomed on or what?' I wasn't too sure. But, of course I don't 'cause it's my marae, it's my land. I could just walk on through, no problem 'cause...I am tangata whenua there already even though I've never been there most of my life...I think I just got a stronger link with backhome these days."

Jamee

Jamee's experience of going onto his marae for the first time and being treated as tangata whenua demonstrates his intrinsic belonging to the place and to it being a perpetual home, no matter where he was before or is afterward. Because of his (re-)connected link with back-home, his relationship with Nūhaka has became stronger and is more secure as it went from being one of mystery, distance and abstraction to one of knowledge, acceptance and belonging. Jamee expressed his inevitable connection to his dad's tūrangawaewae:

"I think it's always there...you just gotta reconnect that with back-home...I can't deny it's part of me anyway, my tūrangawaewae. I'm a part of it anyway through blood through my dad, so I think...I do have tūrangawaewae with my links backhome, definitely...because of my Dad."

Jamee

[Interview: And how about with your links here (in Wellington)?]

"Well, can you have two? \{Laughs\} I don't know. I think on a culture side, definitely I have a tūrangawaewae back-home in Nūhaka ... I'd probably add here [in Wellington] as well to be honest."

Jamee

At the same time Jamee connects the concept of tūrangawaewae to Nūhaka, he also acknowledges belonging to Wellington in a similar, but not equal fashion. For Jamee and others raised and/or dwelling in Wellington for many years, areas within the nation's capital become naturalised forms of tūrangawaewae, similar to what Smith $(2007: 257$ - 
258) describes as one adopting atraditional tūrangawaewae through the process of historical connectivity and affinity to place. Jamee testified to having at least two tūrangawaewae that are distinct in form, substance and meaning from the other: one, his ancestral, and the other, historic. By claiming Wellington as a tūrangawaewae, Jamee 'homes' the place that gives him an additional sense of belonging.

\section{iv. Going Back-Home: Experiences with and Responses to Being 'Othered'}

In journeying to visit one's marae, interviewees, whether they grew-up there or not, have expressed feeling differentiated by those who continue to live there. They expressed being 'othered' through labels which attach them to the city and describe them as being 'urban'. Cellia stated:

"I view myself as still rural... and they view me as urban. You know they give me heaps about 'your flash shoes'."

Cellia

Although Cellia grew up in Wairoa and goes there as often as she can, her dwelling away from home in Wellington becomes reason for people back-home to playfully bother her about her urban lifestyle. Moreover, being away from home becomes reason to designate positions and jobs on the marae accordingly. AT explained what happens when she goes home to Te Hauke:

"You just do what has to be done as if you've never left...[A]lthough they sometimes give you the real shitty jobs \{laughs\}...just to introduce you back in: 'I haven't seen you here often so you get that job'...It's their way of saying, 'Well, welcome back. The more times you come back, your chores will go up a bit'...There'll always be that welcoming presence and that welcoming smile. Although they'll give you a hard time if you've been away too long."

The experiences of my interviewees being 'othered' when at home on the marae, for the most part, are of a harmless nature. Their being 'othered' does not necessarily equate to their exclusion from the community and its functions, as many are given participatory tasks - be them menial jobs, such as peeling potatoes. They are also ways, however, to remind visiting Kahungunu as to where and with whom power resides, at home. Because the ones who live at home care for the mana of the marae, their authority to decide for the 
marae is of higher stature. Yet, it does not mean that those members who do not live there are necessarily excluded from decision-making processes. AT stated:

"At a marae meeting they will always ask for input and...guidance even though we don't live there - I mean, you're still a part of them and they're still a part of you. But at the end of the day because we will hop in our cars and drive back to whatever city we reside in, they are the ones who will always be there."

While AT feels included in the decisions made at home despite not living there, she is also accepting that the final decisions made need to come from the residents of the community as they are the one's who will most directly live with the consequences of the decisions made.

Although many experiences with being 'othered' are innocent, other interviewees expressed feeling treated unfairly and as not being completely accepted by the home community. For example, Tamati described his experience:

[Interviewer: Do you feel that when you go home you are engaged with and looked at differently because you are coming from Wellington, the urban place?]

"Yes. Yes. Yes. Yes. Very much so and it irks me and that's why I don't like that term 'urban Māori' because I think that it's very negative for our people because then when you're back-home you're made to feel like a stranger in your own land."

Tamati

While diverse perspectives were shared by my interviewees regarding the 'urban/rural Māori' divide, Tamati's opinion is one which authenticates its presence and shows how its usage is sustained by the people back-home, especially since he feels that being seen as 'urban Māori' isolates him (in a negative way) from them. Tamati's experience attests that being seen as 'urban Māori' and bringing urban Māori 'ways' back-home can perhaps threaten one's experience of belongingness and weaken one's voice back-home. According to Tamati, being in the urban, extra-Kahungunu diaspora can pose problems for those who want to take an active role in the home community and give to their tūrangawaewae. He continued: 
"Having said that, I understand also from the ones back-home the perspective they have because a lot of the Māori that go back are actually putting pressure... on those little homes when they go back to maraes [sic]...They have a typical tauiwi or Pākehā way of thinking...'My job is to sit here and be a princess or a prince and everyone's gonna wait on me because we've come home'... You see a lot of that, and that's ignorance."

Tamati

Tamati finds fault in the behaviour of some diasporic Māori who do go back-home, but who do so without the intention or openness to be part of the community by working and giving to it the way the community sees fit. Tamati possibly conflates what he describes as the ignorance of the "Pākehā way of thinking" with the negativity he sees in the 'urban Māori' term. He suggests that behaviour associated with both jeopardise the efforts made by those, such as himself, who go back to contribute positively and whole-heartedly to home.

AT, on the other hand, de-essentialises the 'urban/rural Māori' divide by stressing the importance of connections between those back-home and those in the diaspora, whose efforts to contribute to home go largely unnoticed, invalidated, or apprehended by some. She spoke of maintaining ahi kā (roa) while contributing to it from the diaspora:

"We still want to keep the fires burning, you know, and keep things alive, but sometimes I sense this kind of resentment that, 'You guys abandoned us so we're here now; we're the leaders of tomorrow'. Which in...fact, they are leaders of tomorrow but we're only trying to help them become those leaders in a bigger sense, not just within the rohe itself but outside too."

AT suggests that diasporics can play a role that strengthens the home place and community with knowledge and experiences from afar, benefiting the tribe and the land. This is not to imply that there are not roles and responsibilities that the community decides on, but that duties to home can be diversified and shaped by the experiences and skills of the individual and by his/her history, spatial environment, and context.

Tamati addressed the broader exclusionary tendencies of some interpretations of Māori customary notions, such as ahi kā (roa) and mana whenua. He implied dissecting 
the layers of Māori spatial belonging and its adjacent roles and responsibilities that are further complicated by the phenomenon of tribal-diaspora. Playing with re-interpretative approaches to mana whenua and mana tangata ${ }^{105}$, Tamati stated:

"You have to separate out then mana whenua from mana tangata... That's what I mean, we're at this juxtaposition [with] culture and there are a lot of big questions that we're not asking that we're going to be forced to ask. What about the... 120,000 Māori living in Australia, whose kids are getting all these tats and they walk around with their Aussie twang, [saying:] 'But I'm a Māori'? They still got whakapapa. So what will they become... Kahungunu ki Brisbane? You got to ask, is there less validity? ...The big question is what's more important, mana whenua or mana tangata? That's the big question. So if you come to mana whenua, okay then everyone who is outside of the rohe, you're not it. But if you come to mana tangata then that means something fundamentally different...These are fundamental questions that we need to be asking in this day and time."

Tamati

Tamati problematises interpretations of mana whenua that may exclude those who do not reside within their tribal domain. He questions whether, for example, if Kahungunu in Wellington or elsewhere should maintain their mana whenua status only through their 'presencing' on their tribal rohe. Or if in a diasporic context, the concept of mana tangata becomes more relevant in capturing how they live, represent their tribal identity and contribute to the tribe. Tamati calls for a re-examination and re-interpretation of Māori ideas on tribal association and on tribal place belonging. He implies that tribal-diasporic experiences can conjure up the possibility of excluding those who need not be excluded, especially because their activated whakapapa and their desire to contribute to their tribe ought to mean their redemption from such an act. Tamati added:

"What's more important: mana whenua - that's what the ahi kā is, or mana tangata? And if it's mana tangata then we have to realise that that means that our culture has evolved into something else... That's all of that higher level thinking that we're not doing enough of - that culture must evolve, culture must change...

105 Mead (2003:30) notes that 'mana tangata' is associated to "personal increment based on the proven works, skills and/or contributions to the group made over time by an individual". 
We can't expect our kids to be perfect mirrors of ourselves because their environment and the factors that play on their environment and how they do things change."

Tamati

\section{Home Outside of Kahungunu Place}

"The geographic spread of membership should not be seen as threatening the power and economic base of a territory based home group" states Carter, "but as a globally connected membership. In other words, the taura here groups contain a diverse variety of skills and knowledge that could be beneficial to the development of the wider iwi collective" (2006:42; my emphasis). Kahungunu experiences globally and translocally can re-imagine and re-configure Kahungunu belonging to include connected forms of spatiality.

\section{i. Entertaining the Role of Global Routes}

Most of my interviewees lived overseas for a period of time in places such as Australia and Greece, Argentina and Korea. For the most part, their time in these places served to form them in ways that possibly would not have happened had they not left home, wherever that might have been in Aotearoa/New Zealand. Many interviewees described stepping outside of the comfort zone of home and of their local culture, and listed the benefits gained from living overseas: broadened understandings of the world, social relationships of solidarity made across place and cultural differences, and a deeper appreciation for back-home. Their experiences overseas formed them one way or the other, and for some, the places they lived internationally became types of home in their life journey. As an example, AT summoned perspectives on her life in Australia:

"I grew up a lot in Australia. I guess for me at that time I felt that Australia was more my home than New Zealand because it was in Australia where I cut my first tooth...where I learnt to be an adult. It wasn't here in New Zealand...so I've got more of an affinity...in my growing up...to Australia, not to New Zealand...It was in Australia where I first moulded myself to the person I am now." 
AT's time living in Sydney demonstrates that there are intimate connections to extratribal places (established through experiences there) that have not much to do with ancestral place, but that nonetheless can be seen as extensions of it or as inter-woven with one's roots. AT continued:

"[A]11 the other areas...cities...countries that I've lived in, they were a part of my journey. They were a part of...guiding me to who I wanted to be, what I wanted to do, where I will be going. So they were like tools for me to try and pick up all the knowledge as I travelled around and to where I am now. But in saying that Hastings is my home-home only because that's where my pito [is]."

AT described her place routes as being essential parts of her growth, and indeed are parts which do not contradict, but complement her place roots. She explained how places external of Kahungunu territory could add to the story of the Kahungunu tribe through the inter-linking paths walked by its members, making the global not only in the local, but the local very much in the global, too. For AT, her routes benefit her well-being and add to the contributions she can make to Kahungunu, whenever she is ready to return.

AT's experiences demonstrate that home is not to be conceived of solely in terms of a physical place, but as an inseparable force that is gifted through whakapapa. She stated:

"I always felt that I wasn't alone when I was travelling. I knew that my tūpuna were with me the whole time, guiding me."

Home 'moves' with AT, guiding and protecting her in her life. Because AT expressed that in her journeying she never felt parted from home, it is not only located in Te Hauke, but is embodied in the spirit of her ancestors who 'walk' with her. Thus, home is carried within and 'travels' without.

\section{ii. "No Hau e Wha": The Home that Travels}

For interviewees who have a relationship with their tribal-home, travelling to and from there is habitual and normal. Because Wellington is relatively close to Hastings, Te Hiwi frequently travels from one home to the other. He stated:

“[B]eing away from Hastings, it's actually quite normal because when I was growing up we always travelled between Wellington and back-home so I'm 
actually quite familiar just travelling back and forth...I know that three-and-ahalf-hour drive like the back of my hand."

Te Hiwi

For Te Hiwi, both places are linked to and through him and so their relation to each other is better approached by their connectivity and similarity, rather than by their separateness and pure distinction.

Jorgette spoke of (enjoying) the freedom of belonging to many different places and the privilege entailed in claiming them as home:

"Home is where my car is. \{Laughs\} ...In moving to Takapou I moved to my father's tūrangawaewae, so that will be home. But I'm probably not a person that just has one home or will ever have one home in their lifetime...I also feel at home up at the coast. And, also here in Wellington I feel at home...I feel very privileged in that sense. I've got roots. If I want to pull the whakapapa card, I know it well enough, and what's more than that, I've got living relatives who know it and it's legitimate and it's all the rest of it...I feel tied to it but not in an obligatory sense."

Jorgette

Jorgette does not experience home as a static place or a singular notion, but as connected places that she moves to and from. While she feels secure in the place roots of her father, she also identified it as but one example of a home in her life. Jorgette's idea of home is not restricted by her roots; neither is it exempt of the routes she experiences.

Not only did my interviewees identify many different places as (kinds of) home, some preferred not to identify home as located in particular places, per se, but described home as being (in) the space itself that they traverse. For instance, Challen used a metaphor of the wind to describe her sense of home, and of it symbolising her way of belonging to a range of places and people in them that have shaped her life and have become part of her. She expressed:

"I feel like the wind sometimes. Actually a couple of years ago, I decided rather than wheeling off all my whakapapa, I'd actually just say, 'No hau e wha'. I felt like I came from the wind... [F]or me that is solid to feel like the wind and to feel the flow of all those different things that flow through me ... Maybe that's what 
attracts me to this place [Wellington]: that I can stand in one place and still feel blown around."

Challen

Saying that she comes from the wind is a way that Challen acknowledges all the environmental, experiential and ancestral forces that form her. Since the wind encompasses where she has been, where she is and where she will be, it can be applied as a metaphor for the harmony of spatial roots and routes. Challen, like the wind, feels not bound to any place or area in particular but is influenced, nonetheless, by the context of environments in her course. And so, all the places that she has been to, in some way, forge a trail in her life and make their mark on her.

\section{iii. Reconciling Home Roots with Home Routes}

In this chapter we learnt that home may be common and familiar, but it is also highly personal and filled with idiosyncrasies. Through some Kahungunu diasporic experiences in Wellington, connections to Māori (types of) home are approached and analysed, in specific and relational ways, those which include but that are not limited to the social, cultural, spiritual, historic, civic, emotional and residential ways. In accommodating and synthesising all the different approaches to and kinds of home, perhaps returning to the idea of whakapapa would be helpful.

\section{Whakapapa (Part Two)}

"Whakapapa reminds us of our origin, and at the same time reminds us of the connections that stem from those origins. It reminds us that we are connected regardless of location."

$$
\text { Lynette Carter }{ }^{106}
$$

The framework and principles replete within the whakapapa system are ideal for explaining diasporic Kahungunu modes of movement and connection since whakapapa can accommodate for the layers of both spatial roots and routes. It outlines and orders a matrix of layered relationships, "formed in the past and present and [is] the foundation for the relationships that follow" (Carter 2006:42). Whakapapa is a cumulative network of social links and narratives between related people and related things, but can also be used to explain the links between related places. As whakapapa regulates relationships

106 In Carter (2006:42). 
between people and between other elements of the natural and supernatural world, it can do the same for relationships between places.

\section{i. Whakapapa of Place and Whakapapa Tūrangawaewae}

The idea behind whakapapa of place is to reconcile the supposed paradox of Kahungunu translocal and global movement with ancestral place, so that the places journeyed to become part of one's layered spatial genealogy. The idea of whakapapa of place is to bridge paths to, from and of places, for kin-related peoples, weaving together place roots and place routes in non-contradictory, non-discriminatory ways, by focusing on relations rather than on separations. The concept of whakapapa tūrangawaewae, or the genealogy of one's home bases, can perhaps be used to articulate a composite of selected places that have become a place-to-stand for the Kahungunu person or people. Unlike whakapapa of place, whakapapa tūrangawaewae discriminates, as it does not include every place experienced and lived by the person, but only those places that have become intimate reflections of socio-spatial belonging - places that are one's tūrangawaewae.

\section{ii. Whakapapa, 'Critical Thirding' and the 'Third Space of Forms'}

Whakapapa of place conjoins all spatial elements into a moving, but always present and stable sea of 'becomingness'. It invokes the notion of 'becoming' and its conjoined 'third space of forms ${ }^{\prime 107}$ since it includes and pairs ancestral roots (identity/sameness) with diasporic routes (difference/diversity). The idea of a 'critical thirdspace' (Soja 1996:5) can complement whakapapa of place and whakapapa tūrangawaewae. Soja uses a three-tiered conceptualisation of space: firstly, real, concrete space, secondly, imagined, abstract space and thirdly, the space of 'critical thirding' which is constituted of selected elements from both the former spheres, producing real-and-imagined places. Soja moves to new and different modes of spatial thinking by 'critical thirding' in which "the original binary choice is not dismissed entirely but is subjected to a creative process of restructuring that draws selectively and strategically from the two opposing categories to open new alternatives" (1996:5; emphasis in original). Soja's 'critical thirding' of space can be relevant to the idea of the 'third space forms', as well as to the layering systems of whakapapa of place and whakapapa tūrangawaewae. The usefulness of 'critical thirding' here is in its transformative capacity to move from "the categorical and closed logic of

107 See Chapter Three. 
either/or to the dialectically open logic of both/and also" (Soja 1996:60). Like in Soja's idea of a Thirdspace, Kahungunu may 'restructure' and select aspects of their whakapapa of place and whakapapa tūrangawaewae to suit time and space, making its ordering and employment subjective, relational and contextually influenced.

\section{Final Statements on Home}

In the end, Kahungunu 'forms' of home are stable and shifting, located in places that are predictable and unexpected, general and specific. Home, in the Kahungunu world, extends and expands across space-time, and is layered with interacting dimensions. We learn that to understand roots one must first go to the routes (before); and to understand routes, one must journey to the roots. Place belonging in the Kahungunu world, and specifically in a diasporic context, is a real and poetic example of alternating and cyclic roots and routes, spatial stability and fluidity, groundedness to place, and the desire for and attainment of 'reach'. Home for my Kahungunu interviewees is inherited in places somewhere, but is also made in places elsewhere, as home is a journey within as much as it is a journey in and to places without. To borrow from Maaka and Fleras' interpretation of Māori cultural identity, Māori place identity is "constructed as well as inherited, contested yet revered, textual yet contextual, practical yet discursive, lived-in yet ideal, and territorially structured yet de-localised in process" (2005:94). I hope that whakapapa of place and whakapapa türangawaewae can accommodate for the wedded presences of place identity in the lives of my Kahungunu interviewees. 


\section{Chapter Five: Social Organisation}

"It [the Iwi Authority] has to be able to deal with the facts about where our people live, what circumstances make Wairoa different from Greytown, and why a young Kahungunu person in Auckland is quite different from one in Te Hauke."

Ngāti Kahungunu person in Auckland ${ }^{108}$

"This is now our home [in Invercargill], but we are still Kahungunu... [W]e'd hope that there's someway [sic] we can contribute from where we are because the fact is my mokos [sic] will probably never live in Bridge Pa. They've got Ngai Tahu wives but they still know they're Kahungunu...How can we do that in a way where [we] can all be accountable for each other?"

Ngāti Kahungunu person in Invercargill ${ }^{109}$ "It seems obvious to me that we need..[sic] to support and serve the people where they are... [T] hey are shaped by the places where they live, and by the ideas of the city... I predict that unless we structure ourselves to cope with new realities we will be in danger of disintegration as an iwi outside our traditional rohe."

Ngāti Kahungunu person in Wellington ${ }^{110}$

\section{Ngāti Kahungunu Social Organisation}

The opening quotes pose two pressing realities for contemporary Māori society: first, they acknowledge the connected differences between tribal members in places both within and outside of their tribal territory, and second, they suggest that a centralised iwi organisation should respond to the issues formed from those connected differences. In the case of Ngāti Kahungunu, we may ask, how is NKII reaching its Kahungunu members living in Wellington? How are the unique, place-influenced stories of Kahungunu in Wellington communicated to and heard by the Iwi? What is the nature and quality of the

108 This statement was made by a Kahungunu person living in Auckland - identity unknown - in response to a review for internal change and the future orientation of Ngāti Kahungunu Iwi Incorporated, NKII (Ngati Kahungunu Constitutional Review Committee 2000:38).

109 This statement was made by a Kahungunu person living in Invercargill - identity unknown concerning expectations for the Iwi during a NKII constitutional review (Ngati Kahungunu Constitutional Review Committee 2000:12).

110 This statement was made by a Wellington-dwelling Kahungunu person - identity unknown - in response to a hui on the proposed NKII constitutional model in the late 1990's (Ngati Kahungunu Constitutional Review Committee 2000:50). 
relationship between the Iwi and their Wellington-based whanaunga? Are Kahungunu in Wellington organising around their Kahungunu identity; if so, how? Does the coupling of iwi as identity and iwi as organising paradigm (Maaka and Fleras 2005:72) in Wellington reflect the realities lived by my interviewees? The opening quotes and the experiences of my interviewees demonstrate that there is a diasporic Kahungunu community with a uniquely place-specific voice that, while different in some ways from their whanaunga back-home, still wants to be heard and included in the tribe's decision-making processes.

This chapter transitions from engaging with the Kahungunu experience in Wellington on a personal, micro-level to the communal, macro-level of social organisation. (In)formal organisational patterns of my interviewees will be explored, revealing thematic trends of organisation and belongingness to community. As well, the role and function of the Kahungunu Embassy as a specific Wellington-based tribal organisation will be highlighted. It is my intention to highlight the 'distanced' relationship between Kahungunu in Wellington and their rohe-based community, as well as determine the connected nature of that translocal relationship.

\section{i. Ra Waho: Tribal Organisation in the Domestic Diaspora}

Iwi satellite communities organised in places outside their rohe, where there is a large tribal population, are a common phenomenon in Aotearoa/New Zealand. Iwi members up and down the country formally congregate around their specific tribal identity in the diasporic areas where they reside. Generally, initiatives for these satellite communities are coming from and endorsed by some Iwi Authorities in order to reach and stay connected to their geographically dispersed members. Urban tribal groups are not peculiar to Aotearoa/New Zealand either. In the United States, for example, "with the majority of Indian people now living in cities, tribal governments have been forced to become more sensitive to their urban membership and have begun to establish offices in cities where they have significant membership" (Straus and Valentino 2001:89). Yet, as common as these expatriate tribal communities may be, there is little developed research on them, both in Aotearoa/New Zealand and abroad, engaging with issues concerning tribal identity, representation and participation. In a Māori context, Maaka and Carter are

among the few who have addressed the phenomenon of diasporic tribal organisations by studying the satellite communities of their respective iwi - otherwise known as 
"taurahere"111 - Ngāti Kahungunu in Christchurch (Maaka 1994) and Ngāi Tahu in Auckland (Carter 2006).

Taurahere, the rope that binds, is a term used to describe one's enduring connection to whakapapa and to hau kāinga from wherever one may be. Although there is little literature on its use historically, taurahere is believed by some to have described links to specific kin-groups that are maintained despite inter-tribal alliances formed through marriage, migration, et cetera ${ }^{112}$. The phrase "comes from the concept that Māori are bound by spiritual ties to their ancestors and to the land of their tribal origins" (Maaka 1994:333). The term entered the public domain through Matua Whāngai, a governmentsponsored foster-parenting programme begun in 1986 to place young offenders with members of their tribe (Maaka 1994:333, 2003:20). However, with iwi development, taurahere took on "an expanded meaning to describe associations of tribal members who lived outside their tribal territories" (Maaka 2003:20). Consequently, taurahere has become popularly known as a diasporic Māori tribal structure with membership based on descent, domicile and voluntary association. Carter (2006:42) states that the taurahere presence reflects the diversity of contemporary tribal groups and summons the need for government and iwi to rethink how they engage with tribal membership. She suggests iwi do so by reconfiguring their "thinking towards a globally connected group rather than a bounded, exclusive group" (Carter 2006:42).

Because taurahere are organisations that intend to bridge the distance between the diasporic community 'abroad' and the kin-group in the papa kāinga, there is tension as to which voice is to be represented through them: the voice of the diaspora (taurahere members) or the voice of back-home (officially, the Iwi). Many who associate with a taurahere group have a long-standing relationship with their place of residence (Carter: 2006:39), and so their perspectives, needs and concerns are shaped by that reality. Carter (2006:39) asserts that members of a taurahere have dual responsibilities: to the new

111 The concept of 'taurahere' is commonly treated as two separate words ('taura here'). However, I choose to conjoin them as a reflection of how Kahungunu use it in the NKII Constitution, and as a way to avoid confusion in the instances where the English word 'here' is used adjacently. When speaking of the Kahungunu Taurahere in Wellington, I will capitalise it to differentiate it from taurahere.

112 Email correspondence from Anahera Morehu of the Māori Studies Department at Auckland University, 21 April 2010. 
location as well as to their hau kāinga. Yet, in response to the predicament of voice, she is wary of Iwi seeking a one-way exportation of identity and governance from the hau kāinga to the diaspora. Carter states: "The way that iwi have in the past dealt with the issue of taura here membership is to try and control and manage from a centrallystructured organization, based in the home territory. This has met with limited success because members of the diasporic group operate largely autonomously from the home territory" (2006:39). Additionally, Carter (2006:37) notes that because government locks Iwi into localised governance structures, it makes it more difficult for taurahere to participate politically with their Iwi, adding to the fact that their members already lack daily tribal participation. This could imply that some taurahere are designed as apolitical tribal bodies that are erected solely as tribal convoys of one-way cultural transmission ${ }^{113}$.

Some taurahere can and do seek a political voice in the diasporic locale and within their iwi. For instance, Carter (2006) states that they can attempt to claim legal status for purposes of funding, as well as for matters of administration and representation. Yet, she asks, what then becomes of the formal relationship between the taurahere and the hau kāinga, and the reciprocal responsibilities they owe each other (Carter 2006:39). A politicised status, she might argue, defeats the intended purpose of many taurahere, that is, to culturally connect them to their iwi, not alienate them as distinct groups. Maaka on the other hand, approves of the politicised taurahere idea in principle, provided that representation reflects social reality (1994:311). He is cautious, nonetheless, of the practicality and feasibility issues for taurahere seeking legal status and recognition as distinct tribal entities, since the experiences of Kahungunu in Christchurch have demonstrated many such challenges ${ }^{114}$. He states that although "tribal groups in the city will continue to exist, at least while the first generation immigrants are still active, as

113 Some iwi approach, name and define the idea of a diasporic tribal community slightly differently. For example, Ngāti Awa does not officially refer to their extra-rohe tribal communities as 'taurahere'. Within the Ngāti Awa Charter (2005) they are recognised as 'urban hapū' which in turn may imply a (different) set of political consequences from that of 'taurahere'. Maaka (1994) notes how Kahungunu in Christchurch faced multiple problems in the late1980's/early-1990's which included:

- $\quad$ The Runanganui back-home engaging with them ambivalently;

- $\quad$ Failed attempts at establishing a Kahungunu tūrangawaewae in Christchurch;

- Government being financially and resourcefully unsupportive and non-responsive;

- $\quad$ Many Kahungunu being sensitive to forming a new tribe on Ngāi Tahu land, believing they would bend strict traditions which differentiate tribal roles through tangata whenua manuhiri positions. 
social or cultural groups... they will probably remain politically passive" (Maaka 1994:327-328). Maaka hypothesised that in the future, tribal identity will have little tangible effects on the daily life of geographically dispersed tribal members.

\section{ii. Taurahere Rūnanga: Kahungunu Outside of Kahungunu}

"[W]herever you are, wherever you live, we want to reach you, and we want you to reach us... [S]o that the resonance of our tipuna matches the rhythm and pulse of todays [sic] scattered seeds of our iwi"

Ngahiwi Tomoana ${ }^{115}$

NKII recognises the high volume of members who dwell outside of their tribal grounds, and so has established taurahere rūnanga to represent iwi members who are resident within Aotearoa/New Zealand, but who live outside of Kahungunu rohe (NKII website, Taurahere, 2006:5). Only one taurahere rūnanga is to be established for each urban area, provided there is a reasonable population of Kahungunu and that criteria set out by NKII for the formal establishment of a taurahere group is met (NKII 2006:70). Today, there are five Kahungunu taurahere rūnanga ${ }^{116}$ in Auckland, Hamilton, Wellington, Invercargill and Christchurch ${ }^{117}$.

\section{Te Rūnanga o Ngāti Kahungunu (TRONK) ki Te Whanganui-a-Tara}

TRONK ki Te Whanganui-a-Tara is the taurahere rūnanga serving Kahungunu people in Wellington today ${ }^{118}$. Currently, its organisational infrastructure consists of an elected

Consequently, the expatriate tribal organisation became solely a repository of Kahungunu culture as opposed to being a socio-political body working with and on behalf of Kahungunu in Christchurch (1994:326-327).

115 Ngahiwi Tomoana is Chairperson of NKII and his quote was extracted from the editorial section of Hoea rā: Iwi Newsletter Matariki Edition 2009.

116 Although there are currently five Kahungunu taurahere rūnanga, there are only two taurahere seats represented on the NKII board which consists of ten seats in total: one chairperson elected by the board members, six taiwhenua elected by Kahungunu registered to their respective hapū/marae district, two taurahere elected by board members, and one kaumātua elected by Kahungunu kaumātua (NKII 2006:20-21). Two taurahere representatives are appointed to represent the active taurahere rūnanga on the NKII board (NKII 2006:21).

The Christchurch taurahere is currently inactive because no one sits on the rūnanga.

The first Kahungunu taurahere in Wellington began in 1990, Te Rūnanga o Ngāti Kahungunu ki te Upoko-o-Te-Ika. It was an affiliate group of the then, Te Runanganui o Ngāti Kahungunu Inc. (see Chapter Three). During this time, the taurahere was a trust established to promote Kahungunutanga and to focus on building a sound economic base for Kahungunu people in Wellington. One of its endeavours was to emphasise employment and training schemes for Wellington-based Kahungunu. The taurahere was kept alive through a membership fee. 
chairperson and board (of up to ten members) who are elected yearly by registered and non-registered members of Kahungunu ${ }^{119}$. A major priority of the Taurahere's strategic plan is implementing Kahungunu tino rangatiratanga, through forming strategic relationships in Wellington, increasing its membership database and improving its communication strategy.

\section{i. TRONK ki Te Whanganui-a-Tara: Strategic Relationships}

Strengthening the Kahungunu network in Wellington is among the main priorities of the Taurahere rūnanga. It endeavours to do so by establishing and developing key relationships with mana whenua, other Takitimu groups, Te Puni Kōkiri (TPK), Wellington City Council and Ngāti Kahungunu Social Services (Hamilton 2009). The Rūnanga is cognisant of the mana whenua in Wellington and of its own status as manuhiri, as its agendas are realised within the bounds of that relationship ${ }^{120}$. In an interview with the current Chairperson of the Rūnanga, Bill Te Huia Hamilton, he stated:

"I think a big part of... what we do, and... we don't do it with whistles and bells, we do it quietly, is just to support the mana whenua here. Like we don't ask their permission to hold an event, but we engage with them in it, as much as possible... Kahungunu step up in various leadership roles here. But one of the things we don't do is we don't try and represent... any land interests here... ours is sort of more about looking at social and economic opportunities."

The Taurahere's role is seen by Bill to assist mana whenua and other Māori groups in Wellington by providing the Kahungunu perspective. Their relationship with the City Council's Māori unit is, in part, to network with other Wellington-based taurahere groups to establish inter-taurahere communication and alliances. Building strategic partnerships

119 Registered members are identified here as those who are members of Kahungunu listed in the NKII database, and non-registered members are Kahungunu who are not registered to the Iwi. Kahungunu of either status seem to be allowed to vote freely and informally in the Taurahere's AGM, provided they are Kahungunu and residents of Wellington.

120 Although the Rūnanga respects the mana whenua and manuhiri relationship, Bill Te Huia Hamilton stated in our interview that the relationship is quite a complex one since it is influenced by Kahungunu's history in Wellington. See Chapter Three for further information on Kahungunu in Wellington, historically. 
in Wellington is also about reaching Māori business and education networks that can serve as possible avenues for financial support ${ }^{121}$.

\section{ii. TRONK ki Te Whanganui-a-Tara: Membership Database}

Identification and registration of Kahungunu in Wellington is a huge strategic priority for the Taurahere rūnanga. Getting Kahungunu to register means the Rūnanga must identify where their people are, who they are and what their concerns and desires are so that Taurahere plans are relevant to Kahungunu in the region ${ }^{122}$ (TRONK ki Te Whanganui-a-Tara 2008:3). Yet, building its membership database is done just as much for the Iwi's sake as it is for the Taurahere as there is only one registration system (out of NKII) and as Bill Te Huia Hamilton stated in our interview, registrations are mainly collected for it. Since membership registration is a main priority for both the Taurahere and Iwi, it demonstrates that the strategic priorities of both groups are aligned and umbilical. Maaka notes that an iwi's political leverage increases the more publicly affiliated members it has. He suggests that membership with one's iwi may become a requirement in the future, versus being optional (Maaka 2003:253).

While identification and registration are important, they are not without their difficulties. As of January 2010, TRONK ki Te Whanganui-a-Tara had 403 registered members out of a reported 9,759 Kahungunu in the Wellington region (NKII website, Registration). Perhaps this suggests that many Kahungunu in Wellington are registered directly with their taiwhenua, and involve themselves with their iwi through backhome ${ }^{123}$. It could also suggest that many Kahungunu in Wellington are unaware that the Taurahere exists and of its role working specifically with and for Wellington-based Kahungunu. This leads us to explore the communication tactics deployed by the Taurahere to raise its profile and to make it not only visible but also valued by Kahungunu in Wellington.

121 In December 2008, the Taurahere received charitable status. Currently, it relies upon grants used to fund activities to keep the Taurahere functioning and slowly developing.

122 Perhaps increasing its membership database also means that TRONK ki Te Whanganui-a-Tara could have greater representation on the NKII board.

123 Kahungunu who are registered members of NKII are enrolled on its database, choosing to have their rights exercised by their taiwhenua or a taurahere rūnanga (NKII 2006:14). This raises the issue of how diasporic Kahungunu get represented: by their place of ancestry or by their place of residence. Bill is an example of a Kahungunu person living in Wellington who, while being part of the Taurahere, is registered to NKII through his taiwhenua district. 


\section{iii. TRONK ki Te Whanganui-a-Tara: Communication}

Identifying Kahungunu in Wellington, keeping them connected to their iwi and getting them involved in the Taurahere (if they choose) depends upon implementing successful communication strategies. Bill affirmed in an interview:

"Communication is a big thing... [H] ow do we reach the people who see themselves as Kahungunu and Wellingtonians or urban Kahungunu?... My generation is probably [an] emailing generation... the people older than me are post-a-letter-to-me, and the ones younger than me they're, you know, on Facebook and Bebo and... Twitter."

Presently, the communication strategies employed by the Taurahere align with NKII's strategic goals, priorities and plans (NKII website, Communication; TRONK ki Te Whanganui-a-Tara 2008:1). Traditional methods paired with novel technologies are utilised to reach Kahungunu people. These include:

- Word of mouth from face-to-face and phone communications between friends and family;

- $\quad$ A bi-monthly newsletter issued from NKII and sent to every registrant household;

- A 'Board Issues' paper sent out monthly;

- Daily iwi email sent to the NKII database;

- The official NKII website and Taurahere blog;

- A youtube channel called Kahungunu Pride;

- A bi-annual Takitimu Festival held in Hastings, and

- Yearly activities hosted by the Taurahere specifically for Wellingtondwelling Kahungunu, revolving around the Declaration of Independence, Waitangi Day, Matariki, wānanga waiata and an AGM.

All are examples of an intense push by Kahungunu Iwi to help their members get in touch with, stay connected to and develop their iwitanga wherever they might be. Challenges arise however for TRONK ki Te Whanganui-a-Tara to communicate and be active with 
their Wellington community since the Taurahere is no longer funded by NKII, but must be financially self-sustaining ${ }^{124}$.

\section{TRONK ki Te Whanganui-a-Tara: Iwi Representation}

"We have a history of travel and exploration that continues for Ngati Kahungunu today. We must be equipped to take our place in the world while maintaining our kaitiaki status at home. Where ever [sic] we are we acknowledge and celebrate our Kahungunutanga."

NKII website, Kahungunu 2026 Vision Plan-Participating Citizens of the World "New Zealand will know and recognize Ngati Kahungunu Iwi, our values and our iwi rohe."

\section{NKII website, Kahungunu 2026 Vision Plan - Making our Mark}

In its current incarnation, Kahungunu ki Te Whanganui-a-Tara attempts to extend the Kahungunu Iwi voice and vision into the Wellington diaspora. Much of the Taurahere's focus is to stay attuned to and implement NKII's 2026 Vision Plan with the intention that wherever Kahungunu reside they are following, and striving to achieve that same vision. As a result, the Taurahere avoids explicitly claiming and evolving a position of difference, and instead looks to concentrate upon implicit commonalities that aid in developing a cohesive iwi identity and community. It operates as a social vehicle for exercising Kahungunutanga by extending the idea of Kahungunu unity, and sharing in Kahungunu pride and loyalty. These are possibly examples of a current project to cast Kahungunu in the form of a modern nation-state.

\section{i. The Kahungunu Project Today: NKII and Iwi Nation-Building}

NKII currently evokes terminology of statehood which I believe serves as a counterhegemonic discourse of resistance that challenges Crown sovereignty over Kahungunu ${ }^{125}$. At this point in time, the narrative of statehood for NKII seems to be symbolic, but is being developed nonetheless through the discourse of the nation-state ${ }^{126}$. Indeed, a tribal

124 The lack of reliable funds poses challenges in developing the Wellington Kahungunu network, administering and managing the Taurahere, and seeing that its strategic priorities and goals are met.

125 The 'state' is sovereign, in and of itself. The term is used here to imply an authoritative body with territorial integrity, a governing bureaucracy and people as citizens. It has a unified identity, a common state 'language' and is represented in 'eternal' institutions. (While the state also has military power and legal jurisdiction, those and other examples of it are not relevant here).

126 A nation encompass a large group of people bound together mainly through common culture, traditions, values, language, history and territory. It generally has no political implications and can 
community 'imagined' as a "nation-like structure" (Maaka 2003:184) is a social construct and political manoeuvre not unique to Kahungunu. As discussed further in Chapter Three, "iwi, as it is understood today... [has] the form and structure of a modern nation state. The iwi becomes the authoritative voice of a number of subordinate clans and hapu arranged in rigid hierarchies of greater inclusiveness" (Maaka and Fleras 2005:78). Perhaps the idea of iwi nation-statehood is developing in a similar way to that of Kingitanga, Te Kotahitanga or the Māori Party: they are manifestations of Māori selfdetermination using models of sovereignty imported by and familiar to hegemonic systems of rule - in this case, the New Zealand nation-state ${ }^{127}$. By using the sociopolitical technologies of state rhetoric, Kahungunu possibly demonstrates that it has exhausted other methods towards its grand aim of being (recognised as) autonomous.

Kahungunu is a prime example of an Iwi which partially moulds itself after a nationstate by using symbols of statehood. Among the themes of the NKII 2026 Vision Plan (NKII website, Kahungunu 2026 Vision Plan) are for Kahungunu to be participating citizens of the world, striving for tino rangatiratanga, being culturally strong, and making their mark on the consciousness of New Zealanders. Part of being participating citizens of the world is to emphasise that they are Kahungunu citizens representing the Kahungunu iwi-nation, as opposed to being (merely or primarily) citizens of New Zealand. In attempting to create Kahungunu as a nation-state recognised as such by other nationstates, NKII plans to establish embassies wherever Kahungunu people reside in the world (NKII website, Kahungunu 2026 Vision Plan - Participating Citizens of the World). Through the principle of tino rangatiratanga, independence and autonomy are strived for so that Kahungunu are controlling their own resources, making their own decisions, being self-determining, and even asking that New Zealand government boundaries align to their iwi boundaries (NKII website, Kahungunu 2026 Vision Plan - Tinorangatiratanga).

In being culturally strong, NKII states: "Retention of our cultural identity is paramount for it is the soul of the [iwi], what makes us unique. Through concentrated effort and celebration Ngati Kahungunu traditional and contemporary culture and

exist without a state. Yet, the idea of a nation-state marries national identity and governance by a sovereign.

127 I believe NKII's intention when employing the language of the nation-state is part of a decolonising project and not one to completely and permanently re-conceptualise the iwi as a politically 'evolved' nation-state. 
language will survive and achieve national recognition" (NKII website, Kahungunu 2026 Vision Plan - Culturally Strong). NKII plans to popularise Kahungunu culture on a national scale by establishing whare wānanga, Kahungunu publications and Kahungunu sports teams, amongst other endeavours. It also plans that Kahungunu be visible and audible on an inter-national scale by:

- Making the Kahungunu cultural icon - the Paua - an internationally recognised brand;

- Erecting poupou at iwi gateways to mark Kahungunu boundaries;

- Re-instating Kahungunu place names;

- Making Kahungunu reo recognisable, and

- Forming a Kahungunu Parliament (NKII website, Kahungunu 2026 Vision Plan - Making our Mark).

All of the aforementioned serve as examples that work to influence and re-enforce the Kahungunu conception of a unified-self, intentionally assisted through the discourse of iwi-nation and statehood.

Another symbol of the link between Kahungunutanga and statehood is in the Tinhei Kahungunu Passport, launched in the Wairarapa in June 2009. The concept of Tîhei Kahungunu was born out of a marae consultation process in 2001, when NKII leaders visited all 90 Kahungunu marae to introduce a 25 -year vision. During these visits Kahungunu members gave feedback, and an overwhelming desire was shared for a compilation of Kahungunu waiata, history and whakapapa so that Kahungunu across the rohe and beyond could culturally communicate with one another and stand together as a group (Te Puni Kōkiri 2009:25). Unlike most passports which function legally to allow one to move between nation-state borders, Tīhei Kahungunu is concerned with heritage and functions as a vehicle to help Kahungunu connect to and perform Kahungunu roots while en route. It identifies one's citizenry to the Kahungunu community through whakapapa and re-interprets the idea of the passport as a cultural expression of tribal belongingness. The Kahungunu Passport is a 56-page pocket-size booklet containing Kahungunu history, whakapapa, karakia (prayer), pepeha (proverb), oriori (lullaby), mōteatea (lament), haka (dance) and hīmene (hymn) (NKII website, Panui - Tihei 
Kahungunu). It also comes with an accompanying CD with selected waiata from across Kahungunu rohe ${ }^{128}$.

\section{ii. TRONK ki Te Whanganui-a-Tara: Kahungunu Embassy}

"France has got an embassy here [in Wellington], why not Kahungunu?"

\section{Bill Te Huia Hamilton}

On June 25 $5^{\text {th }}, 2008$, the Kahungunu Embassy was blessed and opened in the Wellington $\mathrm{CBD}^{129}$, an initiative begun, headed and enacted by TRONK ki Te Whanganui-a-Tara in pursuit of NKII's 2026 Vision Plan. The idea of establishing a Kahungunu Embassy in Wellington was guided by the same nation-state discourse found within Kahungunu's 25-year plan. Because Wellington is the capital city of New Zealand and is the place where foreign governments represent themselves through the physical and diplomatic mark of an embassy, Kahungunu sees fit to do the same. The founding of the Kahungunu Embassy meant the launching of its office, which symbolises and acts as an 'ambassadorial marae', enabling "Kahungunu to reach out to its own people, to other iwi and to tauiwi including those in international contexts in the time honoured ways of manaakitanga"130 (TRONK ki Te Whanganui-a-Tara 2008:4). Although the Embassy makes a symbolic political statement of nationhood and sovereignty, it is currently and primarily a cultural tool to strengthen, extend and share Kahungunutanga beyond iwi borders and into the metropolis. It is a reflection of what Katz (2001:724) calls a "rooted translocalism" that syncs agendas in one place to those in another by working off the "contours that connect different social formations and their disparate geographies" (Katz 2001:724). Although the Embassy provides a space for Kahungunu coming to Wellington to use, it was established mainly to support and connect Kahungunu descendants in

128 The task of selecting what was to be included in Tīhei Kahungunu was officially assigned to Taumata. Piri Sciascia, Dr. Pita Sharples, Tama Huata and Dr. Rose Pere had the job of choosing what was to be in it, although other staff and a few other iwi members had input, too. They selected waiata from all across Kahungunu rohe, trying to include songs from all the different regions and main hapū. Because not every major waiata could be included in the small booklet, the Kahungunu Passport is only a first edition and volume to a project intended to grow in the near future. Perhaps it can also develop to encompass and express staples of diverse Kahungunu roots and routes. Takitimu whānau. Ariki from Rarotonga came specifically to offer blessings to the organisation and its space.

130 'Tauiwi' implies non-Māori foreigners. 
Wellington to their hau kāinga ${ }^{131}$. It provides a focus for Wellington-based Kahungunu and through its kaituitui (coordinator), ensures that its decisions are implemented, resourced and that the Taurahere's strategic plan is translated into action (Kahungunu Embassy website, About Me).

The Embassy so far proves itself to be an organised articulation that extends the homeland voice, and acts as a reflection of the Kahungunu Iwi vision of tribal nationhood. Both the idea of Kahungunu Iwi nation-building and its consequence, the Embassy, are possibly part of an essentialising project that seeks to clearly define and represent what is 'being' Kahungunu. Yet, since the Embassy also works "on behalf of the Ngāti Kahungunu presence in Te Whanganui-a-Tara to support each other and strengthen connections back-home" (Hamilton 2009), can it, as an organised cultural community that extends Kahungunutanga, simultaneously expand it through its place-specificity? In other words, by extending Kahungunutanga into Wellington through social organisation, is the assumption to be made that Kahungunu in Wellington are 'disconnected' from and 'lacking' Kahungunu cultural markers? Or, can some of those cultural markers be reimagined or added to by the experiences of Kahungunu in Wellington? While an example of an essentialising project, can the Embassy also reflect the pluralism that is Kahungunu and, from the macro-level of organised community, socially embody the concept of a 'third space of forms'. How is a Kahungunu social organisation, like the Embassy, even perceived of and desired by Wellington-based Kahungunu?

\section{The Embassy: Voices from Wellington}

Most of my interviewees had no knowledge of the concept of a taurahere community, let alone being acquainted with or involved in the Kahungunu Embassy. Although the Embassy is a new endeavour, lack of knowledge of what a taurahere group is possibly indicates a lack of awareness in the diasporic consciousness about expatriate tribal groups. In the case of the Embassy, this could imply that its communication strategies are not far-reaching enough. Or, perhaps it suggests that formally organising around a tribal

131 The Kahungunu Embassy and TRONK ki Te Whanganui-a-Tara are the same social organisation, except that the Embassy can be said to be the name of the physical space of the Taurahere.

'Kahungunu ki Te-Whanganui-a-Tara', 'Kahungunu Embassy', and 'Taurahere' are used interchangeably for the remainder of this chapter. The use of 'Rūnanga' specifically implies the Embassy's board. 
identity in Wellington may not be of great concern for many Kahungunu ${ }^{132}$. Nonetheless, varying views were offered on the voice and role the Embassy can and does adopt for Kahungunu in Wellington.

\section{i. The Issue of Voice}

Some interviewees expressed wishing to see the Embassy align with the vision and mission of NKII, functioning largely as a group that extends the Iwi voice outside the rohe, and allows diasporic members to more easily assist in implementing its goals and plans. Te Hiwi expressed that the Embassy ought to reflect the voice of the Iwi Authority: "[T]hey should be running the Embassy from [how] they're being told to from the people back-home... don't want a Ngāti Kahungunu Embassy primarily from a Wellington point of view... I think a lot of the honcho's advice should be coming from back-home which is in the Hastings area."

Te Hiwi

Te Hiwi interprets the purpose of the Embassy as an embodied expression of an iwi form of 'long-distance nationalism' (Schiller 2005) since he believes it should be an extension of the agendas of the tribal-home and of the perspectives of the 'main' tribal community. A Kahungunu Embassy told from a Wellingtonian reality may, in his opinion, defeat the purpose of establishing an iwi embassy in the first place. At worst, it may threaten the links to the hau kāinga, in effect, contradicting the place of taurahere groups for some diasporic members.

Challen, on the other hand, is suspicious of the Embassy's role as being solely an extension of monolithic interpretations and expressions of Kahungunu identity and belonging. She posed the following questions concerning the Embassy:

"How do they speak to all different members? Or is it just... the regulars preaching to the converted?"

Challen

Challen is wary of an organised Kahungunu group that extends univocal notions of Kahungunutanga which, as a result, may overshadow its inherent multivocality. Her

132 This is not to say many do not organise informally around their Kahungunu identity in Wellington. Some do, and many by default, as it is a result of interactions with family, friends and broader Māori socio-cultural networks, as well as being in situations where people may seek to express their Kahungunu identity - such as in a pōwhiri. 
interest is possibly to see a taurahere which embodies expansions of Kahungunutanga as informed by the lived realities and varied experiences and perspectives of its members. The Embassy's Chairperson, Bill Hamilton, shared that the Taurahere must reflect both home and diasporic perspectives - meaning, it must marry extensions and expansions of Kahungunu identity. However, because its strategic plans and mission are mostly fashioned from NKII's 2026 Vision Plan, perhaps there exists an imbalance in design, and in whose voice is ultimately heard and represented.

\section{ii. The Issue of Roles}

Some interviewees expressed the theoretical value of a taurahere community, specifically as a vehicle to connect with back-home. Jorgette gave her impression of the taurahere idea:

"I think they're great in so far as they're a conduit for... opportunity and information... and [that] they're a porthole to what's happening back-home 'cause that would be the advantage of making them iwi specific."

Jorgette

For Jorgette, the idea of a taurahere group is to share knowledge of and from the rohe, especially to those who do not access it easily or readily. The Rūnanga's role would be as a provider or facilitator of Kahungunu information to those who wish to be part of tribal community despite being geographically and culturally distanced from it. Cellia's opinions complement and add to Jorgette's perspectives on the potential of taurahere groups. When questioned about how the Embassy could contribute to Kahungunu life in Wellington, she replied:

"By keeping us informed of what's happening in... NKII... so that we can have our say because... Kahungunu living in Wellington, they have different needs from people living... within the tribal boundaries. And it keeps that whakawhanaunga thing going so you can have hui and meet your... whanaunga."

\section{Cellia}

As someone who already has close ties to back-home, Cellia views the Embassy as a needed tool to grant Kahungunu in Wellington access to participate in a version of the Kahungunu world despite not being on Kahungunu grounds. Additionally, the Embassy can play a valuable role in representing Wellington-based Kahungunu voices to NKII, 
which Cellia noted are unique and worthy of inclusion. It can also work to connect Kahungunu in Wellington not only to back-home, but to each other to form a distinct community that can extend, but also expand the Kahungunu point-of-view.

Not only is the Embassy a potential conduit to culturally, politically and informatively connect diasporic Kahungunu to their Kahungunu home, it can potentially and increasingly play an important social role in the lives of those in Wellington who already have current and strong links to a tribal tūrangawaewae. For Cellia, it provides a space to interact in a culturally familiar way with those from back-home, and gives her an opportunity to comfort them and ease their transition to Wellington. She expressed:

"I want to support people who are Kahungunu living in Wellington, especially people who are from Wairoa... because you know where [they've] come from and you know that they'd be freaked out because Wellington is fast, it's this big city... I'd say to people 'That's okay. You'll end up liking Wellington because I did'... the Embassy gives me a social life."

Cellia

Cellia uses the Taurahere as a support group where Kahungunu in Wellington can connect to others from back-home in attempts to help them better adjust to Wellington and, as she stated, "end up liking" it.

The Embassy has the potential to link people together on the basis of common descent, domicile and voluntary association. However, Cellia believes that Kahungunu people need to emotionally and socially give to the Taurahere, too, especially since the group's strength is dependent upon its constituent parts. She expressed:

"Some don't see how having an Embassy can benefit them and I always say... 'You haven't... seen what they could do... [U]nless you contribute you don't know what they could do'... I know someone who said, 'the Embassy... what will they do for me?' and I said, 'Oh probably bloody nothing. But when your nanny comes down for the claims... it's alright because we will hold a pōwhiri for them. We will make them a cup of tea. The Embassy will make sure nanny gets maanakied [sic]."

Cellia 
Cellia summoned the need for people to invest in community and to not view it as independent of them or in solely abstract terms. The Taurahere can realise its potential and efficiency provided Kahungunu people devote the required time and energy to enliven it. As a social organisation, it can only do as much as the people do for it, since it is an idea dependent upon people's commitment to it. Indeed, Bill expressed that the Embassy wanted and needed input, ideas and energy from the people it is there to work for.

\section{iii. A Kahungunu Place-to-Stand in Wellington}

The existence of an Embassy office as a main outpost for Kahungunu identity in Wellington allows members to better connect to diasporic Kahungunu in a culturally inviting way. Cellia stated:

“I'm really happy we've got an Embassy because now we have somewhere we can actually go, and you can ring up and leave a message, or send an email and if you can, attend a hui... [Before the Embassy] you'd have to... travel to someone's house... or you'd be at another place like Pipitea Marae... or travel to another venue like... Kahungunu Social Services."

Cellia

Maaka attributes one of the impediments of the Christchurch Kahungunu taurahere's development to a lack of material expression of Kahungunu identity: "Having no home base breaks the traditional strong association between people and place that is central to traditional Māori identity” (1994:327). The Embassy's ‘ambassadorial marae' is symbolic of a Kahungunu place-to-stand in Wellington. Although it is not a conventional marae and thus, lacks traditional demarcations of Kahungunutanga, for Cellia, having a physical space that is solely Kahungunu still has its utility and merits. Additionally, perhaps the office space works in the Embassy's favour at an inter-tribal level. A corporate-like tribal office in the Wellington CBD is a less-imposing artifice of Kahungunu identity and community than, for example, erecting a traditional Kahungunu marae in non-Kahungunu rohe might be. On a tribal level, the office keeps Kahungunu in Wellington politically and culturally safe(r).

Although an Embassy office can suffice for some, its physical location can be inconvenient for others. The Rūnanga has difficulty getting large numbers of Kahungunu 
involved in its activities and community which can be partly attributable to the distance some people need to travel to get involved. Te Hiwi suggested the Embassy go out to reach Kahungunu in neighbourhoods where many of them reside. He stated:

"I would love to get more involved in the Embassy but maybe it's just the accessibility of pānui going out to people... Once they got [sic] a good response [they can have] little offices, like maybe one in Porirua and Upper Hutt so people can actually go there and all that sort of stuff."

Te Hiwi

Te Hiwi's statement raises two issues: first, a physical, communal Kahungunu space would be purposeful in places where Kahungunu live instead of just in a centralised location in the city; and second, improved communication strategies may be needed to reach Kahungunu all around the Wellington region. Te Hiwi implies that people's absence from Taurahere hui can be due to a lack of a developed and widespread communication network, as well as to the distances people need to traverse to be a part of an organised Kahungunu community. However, both are challenges the Embassy currently finds difficulty in addressing, especially with regards to lacking dependable funds to implement and execute what may be required for the organisation to reach its fullest potential and function optimally.

\section{iv. Staying Tribally-Connected: The Rope that Binds without the Embassy}

In regards to getting more Kahungunu involved in the Embassy, AT suggested looking at other avenues diasporic Kahungunu utilise to be linked with their tribal world. She stated:

"There may be 9,000 that live here [in Wellington] but... that 9,000 don't get communication from this Taurahere. From a guess they probably get that information from wherever their home is, from wherever [their] taiwhenua is... if they choose to receive that information."

Although some Kahungunu in Wellington may not participate in Kahungunu events, AT points to the fact that that may be the result of many simply going back-home to connect to their tribal identity and find community there. Many do not need to rely on a group like 
the Embassy to connect to their Kahungunutanga because they do so directly through its source. Piri's experience confirms:

“I've been clear to our Ngāti Kahungunu people here - the Embassy people... I said, 'No, I'm not going to be a member of the Taurahere here.' I will sign and my family will sign up as Tamatea, as the taiwhenua from part of Pōrangahau. That's our place that we belong to."

Piri

Some Kahungunu do not participate in the Embassy, because like Piri it may be unnecessary since they sustain active links to back-home. Additionally, the relative geographic proximity between some parts of Kahungunu rohe and Wellington make going back-home fairly easy. AT stated:

"I've been twice to a Taurahere meeting here... To be truthful, if I didn't know Bill [I would have not known about them] and I wouldn't have the energy or the time... to go to those two meetings."

[Interviewer: Why, because it's not part of your reality here?]

"No. I think because I'm so close to home that it's only a get-in-the-car-and-drivefor-three-hours away... I'd certainly [rather] hear it from the horse's mouth."

For AT, participating in the Taurahere is not to connect with back-home, but more as a gesture of solidarity to support fellow Kahungunu in Wellington. However, what the Embassy currently offers - socio-cultural connectivity and socio-political representation - is not of any dire relevance or necessity to her. AT's lack of 'time and energy' to go to Embassy events, and Piri's distance from the Taurahere community, perhaps reflect the way that they view Wellington, as a different kind of space where their tribal identity (and expressions of it) do not need to take precedence.

On another note, in going home, AT does not necessarily flex her iwitanga, per se, but perhaps more specifically, her maraetanga. She explained:

"[I]n terms of attending Kahungunu... meetings: no. I kinda back out of those... If I can, I do attend marae meetings... on what's happening within the village... 
and then I catch up with people."

For AT, gatherings that are largely iwi-focused, as opposed to concentrating on localspecificity, do not necessarily reflect how she relates to her tribal identity. Her Kahungunu identity does not replicate the unified, centralised Kahungunu vision promoted by the Iwi Authority, but is instead based upon the realities of the people on her particular marae. Maaka and Fleras ask us to pay particular attention to the pairing of 'tribe as identity' and 'tribe as organising paradigm' (2005:72) and Maaka (1994:311) notes the necessity of the latter to reflect one's lived reality. Perhaps AT's Kahungunu identity is best reflected through her association to her marae rather than to her Tribal Authority.

\section{Contested Differences}

\section{i. Kahungunu Social Organisation: Reality in Locality}

Some interviewees provided interpretations of their iwi identity which reflect their own social reality. These examples demonstrate that local voice and representation based on difference are broadly experienced themes not restricted to expatriate communities. For example, Tamati expressed viewing the Kahungunu Passport as a good initiative but understood it as a vehicle to construct and promote a unified Kahungunu identity, irrespective of its endogenous or exogenous differences. He stated:

"[I]f you have a good read of it, it all comes back to this Kahungunu thing instead of saying this waiata came out of Heretaunga... and if you want to know about this waiata and you're from this marae here is some wānanga for that... You know they're having one of those... Tīhei Kahungunu wānanga in Nūhaka next week... it makes us angry. Where they see a threat they go in. That's what they've done with Rongomaiwahine."

Tamati

That 'Kahungunu thing' Tamati refers to is possibly akin to the idea of Kahungunu nation-building, since he expresses that it absorbs divergent narratives into its discourse of unity and of an all-encompassing identity. Tamati's frustration comes from his desire to see local tribal cultures, histories, perspectives and realities highlighted as examples of 
differences that matter, versus subsuming them under a supra-package of 'Kahungunu'. Tamati acknowledged NKII travelling wherever Kahungunu reside to promote the Passport, and of its push to develop Kahungunu iwi identity, even in places or for people where it may be secondary to other identities. Although the inception of the Kahungunu Passport came from local consultation, its use, according to some, has been as a tool to strengthen a Kahungunu identity at the expense of those local, regional and tribal differences that compose it - differences Tamati sees as threatening the current discourse of Kahungunu cohesion and sameness.

AT addressed the subsuming of Kahungunu differences by Kahungunu identity too, and pointed to the need to include those voices of difference, particularly at localised levels. She explained:

"Those taiwhenua... they had a lot of animosity towards the setting up of NKII back in the day... actually I think it still happens today... I think they felt... they would [be] left out. All the big decisions would be made in Heretaunga and they won't be consulted on... or they won't see the NKII board members... to come down to their area and talk about this and that. And also to share in the funding... [T] here's gotta be more accountability and more flexibility between the taiwhenua and the board, more communication so that the board can actually come down to the marae and hapū level."

AT identified a deficit of local inclusiveness in the Kahungunu decision-making processes. She suggested that a two-way dialogue between local and centralised levels of communication and decision-making transpire, versus one-way trends of Iwi-to-iwi.

Tamati disapproves of the Iwi-to-iwi equation. He stated:

"[O]n your own marae you have the say, but don't go down the road to the next marae and tell them how to run it... So now with Kahungunu what we've got is... everyone talks about Kahungunu the tangata, the tipuna. But what that's done is that's left our marae and our hapū in despair because we've lost all that knowledge base there. You know, it's all at this higher level."

Tamati 
Perhaps it can be determined from Tamati's statement that the idea of iwi unity has an important function, but it ought to not be treated as the sole mode of being since it can increase the probability of power getting centralised into a single institution and name. The type of Kahungunu centralisation that Tamati refers to is threatening to the diverse nature of Kahungunu identity and social organisation. It also neglects or undervalues local examples of Kahungunu mana and models of self-determination. AT's opinion aligned with Tamati's. She used Iwi communication strategies as an example:

"Kahungunu is quite a big area and communication can be fast or slow, it just depends on who's carrying the message... And the messages will get around Heretaunga, Whanganui-a-Rotu and Wairoa, not so much Dannevirke or the Wairarapa... [I]t'll be slow coming down this way, but it'll stay up in the top or in the middle-part of Kahungunu, and the other three outside it [would say:] 'Oh, we didn't hear that.' I think that [NKII's] just gotta do something real fast otherwise [local groups are] gonna start splitting apart... [Y] our main audience is out in the marae... A]t the moment they use... the iwi radio, word of mouth, pānui letters. That's fine, but I think the face-to-face is better. It's what our people appreciate more."

AT adds to the feeling that more inclusive communication, participation and representation are needed of and within Kahungunu ${ }^{133}$. She stressed the point that groups, such as those in Wairarapa, feel excluded from the Iwi, at least in regards to receiving timely information and participating in 'higher level' decision-making processes. She also suggested that modern communicative technologies should be additions to primary modes of contact - direct face-to-face engagements. This echoes what Te Hiwi and Cellia

133 NKII is aware of the qualms of communication and voice described by AT and felt by many Kahungunu. Bill stated:

"Communication is not as good as it should be... [Some] view that Heretaunga gets everything because it's close to the centre of where the office is. A lot of them see the Kahungunu office and symbol as something that belongs in Hastings - it's got nothing to do with other Kahungunu people because the reach isn't as good...And they judge that on the ability of the Iwi office to pick up on the issues they're concerned about and engage them...[I]n many ways that's what the review is all about."

Every so often NKII has a review to re-evaluate the performance of the board. However, the problems with voice and communication may not necessarily be caused by the board members, but with the type of framework employed; that is, with using the Iwi Authority as a centralised nation-state model. 
expressed earlier in regards to the Embassy going where the people reside. Yet, the role of people - themselves being present at tribal-specific events - is just as pivotal as the direct interactions expected of organised Kahungunu groups, like NKII or the Embassy.

The issue of Kahungunu being absent from organised tribal events in Wellington is not restricted to the diasporic scene. Absence from formal tribal participation and life seems to be a phenomenon gestating at the marae level, too. As well, lack of social and financial investment at the marae level is a recurrent theme. Tamati spoke of its results on local community:

"You go back-home and you go to a marae, you'll be lucky to have twenty or thirty local people in that marae doing the cooking, or [on a] paepae that's constantly full of speakers, or [have] six or seven kuia that can do the karanga, and twenty or thirty songs for the duration of the hui or tangihanga. You won't see it... That's been the result that as an iwi we're strong, but at your power-base level, your marae/hapū level, we're not."

Tamati

Tamati described the lack of human resources and development at the marae level, and of invested interest from the Iwi - the result being weakened local knowledge and authority. While he recognises a robust iwi structure and identity, he also acknowledges an unattended and unhealthy social infrastructure at the grassroots. Perhaps as a result of the growing currency of iwi identity, some Kahungunu are apathetic to local tribal involvement (whether on a marae or at a taurahere). They might assume or expect the work to be done largely from the 'higher level' of iwi organisation ${ }^{134}$. But, rather than interpret a less-active, less-productive and fragile marae-life as being caused by or linked to the processes of a strengthened iwi, the issue of weakened local tribal foundations and voice is one that requires attention nonetheless - and I propose should include the Wellington diasporic experience as a kind of localised Kahungunu voice.

\section{ii. Extra-Kahungunu Thematics}

There are reasons to associate with social assemblages that, while external to Kahungunu heritage, may complement it nonetheless. Many interviewees mentioned

134 Instead of postulating the reasons for the lack of peoples' participation and activity at some marae and taurahere hui, further research needs to be done to address these issues and to determine whether there are even discernable links between the experiences of people in both kinds of environments. 
engaging with people and groups that are passionate about interests that they themselves have. Cellia described her first few years in Wellington, gravitating to people who were of a similar background and way of thinking to hers. She stated:

"I hung out with people who spoke Māori - because [it's] a commonality - people who were from the country and other Māori [who] lived close to Wairoa, like Tūhoe, Ngāti Pōrou."

\section{Cellia}

In transitioning to Wellington, Cellia desired the company of Māori who possessed cultural elements similar to her own lived experience: command of the Māori language, familiarity with Māori rural lifestyle, and those who came from or around her region. Although she did not purposefully seek a community organised on the basis of 'being Māori', she found comfort in people who had experiences that reflected her own cultural reality. Perhaps the type of communities and social networks some Kahungunu gravitate to in Wellington reflect the identities they engage and/or privilege while in the diaspora.

Cellia's experience may reveal that other Kahungunu find community and cultural fulfilment through people and organised groups that are not necessarily Kahungunubased or oriented - or, that in some instances, may even render their tribal identity peripheral. For example, some interviewees mentioned finding community at VUW's Te Herenga Waka Marae, at Ngāti Pōneke and in other examples of urban Māori and pantribal groups - which will be discussed shortly, as well as in industry communities that reflect their line of work and interests. These examples of flexible notions of community and alternative expressions of cultural fulfilment conjure the idea discussed in Chapter Three, that diasporic space renders some identities safer to activate than others (in certain contexts). Yet, more than being culturally safer, finding cultural fulfilment outside of Kahungunu community in Wellington may also mean that some feel more comfortable in broader kinds of communities that reflect their experiences in Wellington.

\section{iii. The Politics of Belonging}

Some interviewees spoke of preferring not to engage with communities that specifically organise around ethnic (or tribal) cultural identity. For example, Jorgette described distancing herself from cultural groups that place emphasis on 'being Māori' or doing things 'the Māori-way'. She stated: 
"[There's] a lot of power-mongering within that environment and people privileging their way of knowing who they are, their understanding of Māori identity over others... So cultural groups, unfortunately, I think they're riddled with people like that and we don't get along, at all."

Jorgette

Jorgette is cautious of culturally-based group environments with people who place rules or expectations on how others are to live, experience and express their cultural identity since they often produce unwelcoming feelings of exclusion. Although she was speaking of Māori groups specifically, her aversion to them perhaps echoes what others feel in regards to engaging with other culturally-specific communities, such as the Kahungunu Embassy. For instance, Lisa expressed fear in participating in Embassy wānanga:

"[I]t would be good to learn... Kahungunu-specific dialect... that's why I want to go to that next [Embassy] hui... But yeah, I've always been a bit scared to go to those."

Lisa

Lisa's lack of involvement with the Taurahere may possibly and partly come from a fear of being judged by her community, specifically by those who possess a greater or more recognisable cultural fluency than her. Although the Embassy may not encourage singular ways of 'being Kahungunu' and expressing Kahungunutanga, the experiences of some people with other Māori groups may carry-over nonetheless. As well, participating in a culturally learned environment - perhaps learning things Kahungunu may feel they should already know - might spawn feelings of unease, distress, timidity, and avoidance of organised Kahungunu community in some.

Challen described her reservations with participating in Māori communities since her experiences have been that many people within them privilege particular ways of being over others. She stated:

"Every so often I might integrate myself into Māori communities although not very often. I feel quite uncomfortable in Māori communities."

Challen

[Interviewer: Why? Why do you think that is?] 
"I don't really know why... I found myself bound by these invisible ties or belts... I don't think there is as much unity in Māori communities as portrayed. I think actually it's a lot more vicious to be honest; and cliquey. I mean I'm part of a Māori organisation and I find it very cliquey.”

Challen

Challen described feeling primarily uncomfortable in Māori communities, since her experiences in them have caused her to feel unaccepted and alienated by being different. The rigid criteria for being part of a 'clique' - highlighted by, what Challen says are, "invisible ties" - demonstrate the power of criteria expected of members, in order for some of them to feel part of the community. One's validation of belonging is confirmed by being 'cliquey'. Yet, because Challen does not function in communities in such a manner, she circumvents Māori cultural groups, or at least from fully participating in them, in her attempts to avoid not fitting-in.

Of course, not all Māori groups place high emphasis on cultural criteria as a form of validity and belonging. Jorgette spoke of her pleasant experiences with a Māori group that was a kickboxing club:

"It was the best way really because the focus wasn't on being Māori, you just are Māori. There are just little things which remind you that we're part of a bigger thing, that we are a whānau... such as the karakia both at the beginning and at the end...You recognise the whare as you go in and... as you go out. [The instructor] flips between Māori and English. So, that's the kind of Māori environment I like to be in... the focus is on the kick-boxing, how you are going, your strength, yourself, your development, supporting one another to do their best not on just being Māori. The just being Māori bit is a given."

Jorgette

The experience of not proving her 'Māoriness', but instead of being accepted and of accepting everyone whilst working together towards a common goal - fitness - produced a more positive experience of Māori groups for Jorgette. Knowing the attributes she found positive and valuable in the kickboxing club may aid in discerning what kind of community some Kahungunu who are affected by experiences of exclusion or alienation within Māori groups may want and need. 
In regards to the Embassy, its main focus is to provide for the Wellington-based Kahungunu community, primarily through culturally-based activities, such as wānanga waiata. Consequently, because in the Taurahere context, culture is one of the main reasons to organise, many Kahungunu may benefit from a non-judgemental environment that is open, creative and fun in regards to sharing and learning cultural identity. When asked what she expects from the Embassy, Lisa stated:

"I expect them to be truly welcoming, to make us feel comfortable when we're ready to get there, ready to engage... we actually need that welcoming. Yeah, that it's okay, come in and we'll help you learn and to feel comfortable with what you're learning."

Lisa

Lisa noted that choosing to participate in an organised Kahungunu community is a personal decision dependent upon one's journey. Yet, it is also influenced by selfconfidence and trust in the community. The need to feel welcomed reflects Lisa's preference for a non-discriminatory environment which is more conducive to the brave act of inter-personal sharing and effective participation in tribal-based groups. Indeed, during my own experiences at the Embassy, many people shared similar stories and were, themselves, the architects of creating such an environment.

The inclusion of children in and by the organised Wellington Kahungunu scene is another common theme noted by some of my interviewees. Lisa expressed wishing there existed options for children in regards to learning about and sharing their Kahungunutanga:

"Kahungunu rangatahi groups outside of the rohe... I think it would be a good thing... 'cause I suppose a lot of that [Embassy] stuff is geared to the adults... all the iwi hui and stuff... that's more for grown-ups. So what I would have liked maybe when I was younger was just something that I could identify with without my mum."

Lisa

Lisa would like to see youth-based Kahungunu groups develop that help expose children to organised tribal communities in the place where they domicile without relying solely on their parents. She suggested that organised diasporic Kahungunu communities 
specifically target Kahungunu youth so as to include the perspectives and experiences of the next generation - especially those most influenced by the domiciliary environment in which they are raised.

In the future, the Kahungunu Taurahere can potentially become a distinct hapu or separate tribe that truly and only represents the specific voice of WellingtonianKahungunu $^{135}$. Tamati explained:

"With urbanisation we're now up to second generation, third generation of our tamariki who were born in Wellington who are Kahungunu. So for them, their hapū might become Kahungunu ki Te Whangaui-a-Tara. And that could be a valid hapū for them in the future, even though their mum might have come from Wairoa or Hastings or wherever."

Tamati

Tamati's perspective recognises the increasing reality of Kahungunu growing-up and living away from their hau kāinga in Wellington - possibly even making it some collective form of tūrangawaewae. However, many Kahungunu will continue to move to the capital city at some point in their life and make Wellington home. Consequently, a social organisation that can reflect varying realities may still be in demand to service and represent a wide-natured tribal community. Cellia stated what members of such a group can offer their community now:

"[They can do] whakapapa wānanga so people know who they are, where they come from and how they fit in the scheme of things. Then they also get an idea of actually who's related... The whole wānanga of learning waiata... so when you stand up as Kahungunu together, you can sing a song... So it's about creating relationships between each other... They could also visit... our older people who perhaps their children have moved out of Wellington or are busy. To take the people to them so that they're not going to the people or having to travel... let them know what we're doing... [W] e presume they are all on the internet... but of

135 Te Taurahere o Ngāti Pōrou ki Tāmaki, or the Ngāti Pōrou taurahere in Auckland, may be an example of a separate, place-specific iwi forming in the diaspora, especially as a consequence of the group not receiving any funding from Te Rūnanga o Ngāti Pōrou (Te Taurahere o Ngāti Pōrou ki Tāmaki 2008:5). 
course that's just wrong."

Cellia

A Wellington expatriate Kahungunu community that reflects a diversity of voices - old and young, (sub)urban and rural - and that flexibly accommodates for various kinds of Kahungunu difference - regional and tribal - could include those who may otherwise feel excluded. Indeed, the Rūnanga is an experiment in organised and localised attempts at socially navigating, negotiating and mediating through the unity of (these) collective differences. Here, the 'third space of forms' may be useful on a social paradigmatic level to bridge the needs of upholding Kahungunu identity and reflecting Kahungunu diversity, so as to speak equally from and to both.

\section{Tension of Voice: Possible Resolutions}

What I understand as a tension of Kahungunu voice in the taurahere idea is not only due to the diverse perspectives and experiences of its members in the capital city and region. It has to do with the Taurahere trying to balance being a community that reflects both the 'Kahungunu iwi-nation' and Wellington-based Kahungunu who desire to be part of a domiciliary-based tribal community. A re-consideration of identity and purpose may be needed of Kahungunu ki Te-Whanganui-a-Tara so that the groups' strategic plans and mission are more adequately aligned with what Kahungunu people need from it, and to how it sees itself - either as an ambassadorial voice that speaks on behalf of those backhome, or as a diasporic group representing those in Wellington. Indeed, it can be and do both, yet the answer might need to be guided by what Kahungunu in Wellington who associate to it require and want. If it is to be a combination of Iwi and local voice, it will possibly see:

1) The same tensions noted on local tribal and marae levels;

2) The continued tensions regarding ambivalence or exclusion felt by some in Wellington and,

3) The need to reconcile its explicit difference within a sincere project of tribal cohesion and unity.

A clear self-identity from the Taurahere may attract the audience that can most gain from its type of community. Although its current role is largely to give what is perceived to be 
'lacking' of Kahungunu in Wellington, the Taurahere's identity could be allowed to evolve further.

To increase communication to and participation of Kahungunu means that the Taurahere continue to reflect the realities lived by its people. The Embassy can possibly attract a greater percentage of Kahungunu through events that reflect their 'Wellington personality'. For example, hosting concerts, sports tournaments, fitness programmes, dating events for single Kahungunu, volunteer services (possibly for Kahungunu elderly), family and youth-oriented activities, and so forth ${ }^{136}$; things that are not traditionally Kahungunu per se, but that nonetheless appeal to the Wellington side of who they are, and by adding a tribal 'twist' that reminds them of that identity, too. The initiatives the Embassy currently takes are needed and of great value, yet additional approaches can only serve to enrich what they are already doing.

\section{Organised Kahungunu 'Forms'}

To conclude, can a theory of Forms - that which attempts to strategically and coherently unite identity and difference, tribal home and diaspora - be applicable on the level of a (trans)local tribal social organisation such as the Embassy? Can the Embassy be both a culture-based and place-based project, simultaneously and successfully? While it currently may be an example of "multi-scale, network-oriented...strategies of localization" (Escobar 2001:139), to which place is it to be 'localised'? A diasporic Kahungunu project of localisation may be to two differing centres - on the rohe and in Wellington. Or, perhaps the metaphor of taurahere can be used to explain that the 'rope that binds' Kahungunu, connects them not necessarily to fixed locales or centres back on the tribal rohe or even in the diaspora, but to a vast and growing tapestry of linked and 'moving' centres. The Embassy currently faces a challenging, yet important road to institutionally embody the 'forms' of Kahungunu. The Kahungunu Taurahere is a powerful idea that encompasses a huge potentiality for experimentation and growth, a process which Kahungunu, like those I interviewed, can contribute much to.

136 The suggestions for Embassy outreach provided here emerged from the interviews and from the researcher. 


\section{Chapter Six: Conclusion}

\section{Conclusion}

\section{i. Summary}

In this thesis, I attempted to establish the various ways that some Kahungunu in Wellington today articulate, maintain and transform their Kahungunu identity by problematisng the themes of iwi identity, home and social organisation in their daily lives. Prior to doing so, I introduced the relationship between myself and the research, and provided the thesis genealogy in Chapter One. Chapter Two continued to situate the work by explaining the thesis methodology, and it foreshadowed problematising binary juxtapositions in the politics of identity and belonging. In Chapter Three, I argued that Diaspora theory can help to position 'rooted' and 'routed' ways of articulating what is Kahungunu, while a theory of a 'third space of forms' could possibly reconcile manifestations of Kahungunu identity with Kahungunu difference. I maintained that while Kahungunu identity might be constant, it is never a finished or complete product since it intermingles with internal and external examples of difference that move individuals in a perpetual state of 'becomingness'. Chapter Four captured the dynamic nature of home for my interviewees and how understanding that dynamism is necessary, especially since 'home' is pivotal for providing a sense of belonging to them. Ideas around whakapapa of place and whakapapa tūrangawaewae were highlighted as ways to possibly accommodate for the many (kinds of) places that are and can become home - Wellington included. The chapter focused on the connections, rather than on the separation between Kahungunu people and the places that form them. It expanded the concept of a 'third space of forms', spatially. In Chapter Five, I explored the role and potential of a Kahungunu social organisation, the Kahungunu Embassy, on the lives of Wellingtonbased Kahungunu who may wish to associate with it. In this chapter, I attempted to extend a theory of Forms from an individual level to a collective level of social organisation. I argued that as a taurahere group, the Embassy has the challenge of balancing Kahungunu identity and agendas from back-home with the experiences, needs and concerns of Kahungunu lives 'forming' predominantly in Wellington. Each of the main chapters played a role in focusing and elaborating on a pivotal element of 
'be(com)ing' Kahungunu; that is, what Piri Sciascia identified as constituting his Kahungunu identity: whakapapa, a place to stand, and belongingness to a group ${ }^{137}$.

\section{ii. Closing Remarks}

My interviewees have complex understandings of and relations to 'be(com)ing' Kahungunu. They are complex because they are dynamic, creative, challenging and adaptable - facets which they embody and express in their everyday lives. As described in Chapters Three, Four, and Five, Kahungunu membership is exclusive. That exclusivity is associated to how identity, spatiality and belongingness are generally perceived by the Iwi and internalised by some Kahungunu. Yet, while it is exclusive, it need not exclude the unconventional and divergent processes that influence and reflect how its members live. I hope this thesis stimulates further reflection on how socio-historical circumstances and currently lived experiences away from a tribal-home add depth to the way inclusiveness and differences within the group can be imagined. The realities of some Kahungunu, as articulated in this thesis, are indicative of what Te Ururoa Flavell has stated, that "we must never lose sight of the value that can be gained through opening our eyes to different ways of being" (2006:2). To keep our eyes shut and our ears closed to the significance and insight of the different ways of 'be(com)ing' Kahungunu may lead to unnecessarily isolating people, ideas and experiences who can otherwise embody a microcosmic example of the splendour in living together, differently.

137 I further elaborate on Piri Sciascia's comment in Chapter Three. 


\section{References}

Alasuutari, Pertti, 2004. Social Theory and Human Reality. London: Sage.

Aluli-Meyer, Manulani, 2008. Indigenous and Authentic: Hawaiian Epistemology and the Triangulation of Meaning. In Norman K. Denzin, Yvonna S. Lincoln and Linda Tuhiwai Smith (eds), Handbook of Indigenous and Critical Methodologies. Los Angeles: Sage, pp.217-232.

Anderson, Benedict, 1983. Imagined Communities: Reflections on the Origin and Spread of Nationalism. London and New York: Verso.

Appadurai, Arjun, 1988. Putting Hierarchy in Its Place. Cultural Anthropology, 3(1):3649.

Arksey, Hilary and Peter Knight, 1999. Interviewing for Social Scientists. London: Sage.

Asher, George and David Naulls, 1987. Maori Land. Wellington: New Zealand Planning Council.

Babbie, Earl, 1998. The Practice of Social Science. Belmont: Wadsworth. $8^{\text {th }}$ edn.

Ballara, Angela, 1990. Te Whanganui-a-Tara: Phases of Maori Occupation of Wellington Harbour c. 1800-1840. In David A. Hamer and Roberta Nicholis (eds), The Making of Wellington 1800-1914. Wellington: Victoria University Press. 1991. The Origins of Ngāti Kahungunu. Unpublished Ph.D. thesis, Victoria University of Wellington. 1998. Iwi: The Dynamics of Māori Tribal Ogranisation from c. 1769-1945. Wellington: Victoria University Press.

Barcham, Manuhuia, 1998. The Challenge of Urban Maori: Reconciling Conceptions of Indigeneity and Social Change. Asia Pacific Viewpoint, 39(3):303-314. 2000. (De)Constructing the Politics of Indigeneity. In Duncan Ivison, Paul Patton and Will Sanders (eds), Political Theory and the Rights of Indigenous Peoples. Cambridge: Cambridge University Press, pp.137-151. 2004. The Politics of Māori Mobility. In John Taylor and Martin Bell (eds), Population Mobility and Indigenous Peoples in Australia and North America. London: Routledge, pp.163-183. 
Bedford, Richard, Robert Didham, Elsie Ho and Graeme Hugo, 2004. Maori Internal and International Migration at the Turn of the Century: An Australasian Perspective. New Zealand Populations Review, 30 (1\&2): 131-141.

Best, Elsdon, 1919. The Land of Tara and They Who Settled It: The Story of the Occupation of Te Whanga-nui-a-Tara (The Great Harbour of Tara), or Port Nicholson, by the Maoris. New Plymouth: Journal of the Polynesian Society.

Biggs, Bruce, 1989. Humpty-Dumpty and the Treaty of Waitangi. In Ian Hugh Kahwaru, Waitangi: Maori and Pakeha Perspectives of the Treaty of Waitangi. Auckland: Oxford University Press NZ, pp.300-311.

Bishop, Russell and Ted Glynn, 1999. Researching in Maori Contexts: An Interpretation of Participatory Consciousness. Journal of Intercultural Studies, 20(2):167-182.

Borell, Belinda, 2005. Living in the City Ain't So Bad: Cultural Diversity of South Auckland Rangatahi. Unpublished Masters thesis, Massey University.

Bourdieu, Pierre, 1992. The Practice of Reflexive Sociology (The Paris Workshop). In Pierre Bourdieu and Loïc J.D. Wacquant (eds), Invitation to Reflexive Sociology. (eds.) Chicago: University of Chicago Press, pp. 217-260.

Brown, Leslie and Susan Strega, 2005. Transgressive Possibilities. In Leslie Brown and Susan Strega (eds), Research as Resistance: Critical, Indigenous and AntiOppressive Approaches. Toronto: Candian Scholars' Press, pp.1-17.

Brubaker, Rogers and Frederick Cooper, 2000. Beyond "identity". Theory and Society, 29:1-47.

Butcher, Margot, 2003. What is Maori? Who is Pakeha? In North \& South. Issue 209:3647.

Buttimer, Anne, 1980. Home, Reach, and the Sense of Place. In Anne Buttimer and David Seasmon (eds), The Human Experience of Space and Place. London: Croom Helm, pp.166-187.

Byrnes, Giselle, 2004. The Waitangi Tribunal and New Zealand History. Melbourne: Oxford.

Carter, Jacq, 1998. None of us is what our Tūpuna were: When "Growing Up Pạ̄keha" is “Growing Up Māori”. In Witi Ihimaera (ed.), Growing Up Māori. Auckland: Tendum, pp.253-267. 
Carter, Lynette J., 2003. Whakapapa and the State: Some case studies on the impact of central government on traditionally organized Māori groups. Unpublished Ph.D. thesis, University of Auckland. 2005. 'Naming to Own: Place Names as Indicators of Human Interaction with the Environment'. An International Journal of Indigenous Scholarship, the Journal of Ngā Pae o Te Māramatanga, 1(1):7-25.

2006. "Home" and "Location": The Problem of Place as an Ethnic Identifier. International Journal of the Humanities, 4(3):33-44.

Castree, Noel, 2004. Differential geographies: place, indigenous rights and 'local' resources. Political Geography, 23(2):133-167.

Clarke, Richard L. W., 2006. From Dialectic to Différence: Rethinking Creolisation in the Later Work of Stuart Hall. Shibboleths: Journal of Comparative Theory, 1(1):3755.

Clifford, James, 1994. Diasporas. Current Anthropology, 9(3):303-338. 2007. Varieties of Indigenous Experience: Diasporas, Homelands, Sovereignties. In Marisol de la Cadena and Orin Starn (eds), Indigenous Experience Today. Oxford: Berg, pp.197-223.

Cram, Fiona, 2001. Rangahou Māori: Tōna tika, tōna pono - The validity and integrity of Māori research. In Martin Tolich (ed.), Research Ethics in Aotearoa New Zealand: concepts, practices, critique. Auckland: Longham, pp.35-52.

Douglas, Edward M.K., 1983. Mana whenua, mauri tangata: exploring the relationship between Maori identity and the land. Dunedin: Pacific Science Congress.

Dufoix, Stéphane, 2008. Diasporas. Berkeley: University of California.

Dunbar, Christopher, 2008. Critical Race Theory and Indigenous Methodologies. In Norman K. Denzin, Yvonna S. Lincoln and Linda Tuhiwai Smith (eds), Handbook of Indigenous and Critical Methodologies. Los Angeles: Sage, pp.85-99.

Durie, Mason, 2003 Ngā Kāhui Pou. Launching Mãori Futures. Wellington: Huia. Escobar, Arturo, 2001. Culture sits in places: reflections of globalism and subaltern strategies of localization. Political Geography, 20:139-174. 
Flavell, Te Ururoa, 2006. Gen. Debate: Flavel 'Bridging Cultural Spheres'. [Internet.] [Retrieved 7 May 2010.] Available from http://www.scoop.co.nz/stories/PA0609/S00145.htm.

Fixico, Donald L., 2000. The Urban Indian Experience in America. Albuquerque: University of New Mexico Press.

Forbes, Jack D., 2001. The Urban Tradition among Native Americans. In Susan Lobo and Kurt Peters (eds), American Indians and the Urban Experience. Walnut Creek: AltaMira Press, pp.5-25.

Fuss, Diana, 1989. Essentially Speaking: Feminism, Nature \& Difference. New York: Routledge.

Giddeons, Anthony, 1990. The Consequences of Modernity. Cambridge: Polity Press.

Gilroy, Paul, 1993. The Black Atlantic: Modernity and Double Consciousness. Cambridge: Harvard University Press.

1994. Black Cultural Politics: An Interview With Paul Gilroy by Timmy Lott. Found Object, 4:46-81.

Grace, Patricia, Irihapeti Ramsden and Jonathan Dennis, 2001. The Silent Migration: Ngāti Pōneke Young Māori Club 1937-1948. Wellington: Huia.

Guerin, Pauline, Linda Waimarie Nikora and Mohi Rua, 2006. Tūhoe on the Move: Regional Mobility. New Zealand Population Review. 32(2):65-90.

Hall, Stewart, 1990. Cultural Identity and Diaspora. In Jonathan Rutherford (ed.), Identity: Community, Culture, Difference. London: Lawrence \& Wishart, pp.222237.

1992. The Question of Cultural Identity. In Stewart Hall, David Held, and Tony McGrew, Modernity and its Futures. Cambridge: Blackwell, 1992, pp.273-325. 1995. New cultures for old. In Doreen Massey and Pat Jess (eds), A Place in the World: Places, Culture and Globalization. Oxford: Oxford University Press, pp.175-213.

2002. The West and the Rest: Discourse and Power. In Susanne Schech and Jane Haggis (eds), Development: A Cultural Studies Reader. Oxford: Blackwell, pp.5664. 
Hamer, Paul, 2007. Māori in Australia. Ngā Māori i Te Ao Moemoeāa. Wellington: Te Puni Kōkiri.

Hamilton, Te Huia Bill, 2009. Chairperson's Report. Unpublished paper presented at Ngati Kahungunu Embassy AGM, Wellington, August 22, 2009.

Harris, Aroha, 2007. Dancing with the State: Maori Creative Energy and Policies of Integration, 1945 - 1967. Unpublished Ph.D. thesis, University of Auckland. 2009. "Sharing Our Differences Together": Whakapapa of Experience in PostWar Auckland. Unpublished paper presented at AIATSIS National Indigenous Studies Conference, Canberra, October 01, 2009.

Heidegger, Martin, 1969. Identity and Difference. Translated from German by Joan Stambaugh. New York: Harper \& Row.

Hubbard, Phil, Rob Kitchen, Brendan Bartley, Duncan Fuller, 2002. Thinking Geographically: Space, Theory and Contemporary Human Geography. London: Continuum.

Ihimaera, Witi, 1998. 'Introduction'. In Witi Ihimaera (ed.), Growing Up Māori. Auckland: Tandem, pp.11-16.

Ingold, Tim, 2009. Against Space: Place, Movement and Knowledge. In Peter Wynn Kirby, Boundless Worlds: An Anthropological Approach to Movement. New York: Berghahn Books, 29-43.

Innes, Robert Alexander, 2009. "Wait a Second. Who Are You Anyways?" The Insider/Outsider Debate and American Indian Studies. American Indian Quarterly, 33(4):440-461.

Irwin, Kathie, 1992. Towards theories of Māori feminism. In Rosemary Du Plessis, Feminist Voices: Women's Studies Texts for Aotearoa/New Zealand. Oxford University Press, Auckland, pp.1-21.

Jacobs-Huey, Lanita, 2002. The Natives are Gazing and Talking Back: Reviewing the Problematics of Positionality, Voice and Accountability among "Native" Anthropologists. American Anthropologist, 104(3):791-804.

Kahungunu Embassy, n.d. About Me. [Internet.] [Retrieved 2 June 2009.] Available from: http://www.blogger.com/profile/06109723888759380086. 
Kalra, Virinder S., Raminder Kaur and John Hutnyk, 2005. Diaspora \& Hybridity. London: Sage.

Katz, Cindi, 2001. Vagabond Capitalism and the Necessity of Social Reproduction. Antipode 33 (4):709-729.

Keenan, Erin, 2009. Stories of Continuity, Time of Change? Māori Oral Histories of Urbanisation, 1945-1970. Unpublished paper presented at AIATSIS National Indigenous Studies Conference, Canberra, October 01, 2009.

Kidman, Joanna, 2007. Engaging with Māori communities: An exploration of some tensions in the mediation of social science research. Auckland: Ngā Pae o te Māramatanga.

Kirby, Peter Wynn, 2009. Lost in "Space": An Anthropological Approach to Movement. In Peter Wynn Kirby (ed.), Boundless Worlds: An Anthropological Approach to Movement, New York: Berghahn Books, pp.1-27.

Ladson-Billings, Gloria and Jamel K. Donner, 2008. Waiting for the Call: The Moral Activist Role of Critical Race Theory Scholarship. In Norman K. Denzin, Yvonna S. Lincoln and Linda Tuhiwai Smith (eds), Handbook of Indigenous and Critical Methodologies. Los Angeles: Sage, pp.61-83.

Lattuca, Lisa R., 2001. Creating Interdisciplinarity: Interdisciplinarity Research and Teaching among College and University Faculty. Nashville: Vanderbilt University Press.

Lilomaiava-Doktor, Sa'iliemanu, 2009. Beyond "Migration": Samoan Population Movement (Malaga) and the Geography of Social Space (Vā). The Contemporary Pacific, 21(1):1-32.

Maaka, Roger, 1994. The New Tribe: Conflicts and Continuities in the Social Organization of Urban Māori. The Contemporary Pacific. 6 (2):311-336. 2003. Perceptions, Conceptions and Realities: A Study of the Tribe in Maori Society in the Twentieth Century. Unpublished Ph.D. thesis, Canterbury University. and Augie Fleras, 2005. The Politics of Indigeneity: Challenging the State in Canada and Aotearoa New Zealand. Dunedin: Otago Press. 
Massey, Doreen, 1994. Space, Place and Gender. Minneapolis: University of Minnesota Press.

1999. Power-geometries and the politics of space-time. Heidelberg: University of Heidelberg.

McDowell, Morag and Duncan Webb, 1998. The Treaty of Waitangi. In Morag McDowell and Duncann Webb (eds), The New Zealand legal system: structures, processes and legal theory. Wellington: Butterworth, pp.189-233.

McEwen, Jock, 1972. Migrations to and settlements of the Wellington area: a series of 4 lectures. Wellington: Department of Anthropology, Victoria University.

McIntosh, Tracy, 2005. Maori Identities: Fixed, Fluid, Forced. In James H.Liu, Tim McCreanor, Tracey McIntosh and Teresia Teaiwa (eds), New Zealand Identities: Departures and Destinations. Wellington: Victoria University Press, pp.38-51.

Mead, Hirini Moko, 1997 . Landmarks, Bridges and Visions: Aspects of Māori Culture: Essays. Wellington: Victoria University Press. 2003. Tikanga Māori: Living by Māori Values. Wellington: Huia. and Groove, 2001. Ngā Pēpeha a Ngā Tïpuna. The Sayings of the Ancestors. Wellington: Victoria University Press.

Mendoza, S. Lily, 2002. Between the Homeland and the Diaspora: The Politics of Theorizing Filipino and Filipino American Identities. New York: Routledge. Meredith, Paul, 2000 . Seeing the 'Māori Subject': Some Discussion Points. In Ani Mikaere and Stephanie Milroy (eds), Ki te ao mārama: tenth anniversary hui- $\bar{a}-$ tau: conference proceedings. Hamilton: Maori Law Society, pp.36-45.

Morehu, Anahera, 2010. Taura here search. [Email]. (Personal communication, 21 April. 2010).

Morgan, George, 2006. Unsettled Places: Aboriginal People and Urbanisation in New South Wales. Kent Town: Wakefield Press.

Morseu-Diop, Noritta Pele, 2008. The Challenges of Indigenous Qualitative Research within a Mainstream Australian Academic Context: A Torres Strait Islander Perspective. Zenadth Kes I, Torres Strait Islander, 1:54-63.

New Zealand Ministry of Justice, 2001. He Hīnātore ki te Ao Māori. A Glimpse into the Māori World: Māori Perspectives on Justice. Wellington: Ministry of Justice. 
Ngati Kahungunu Constitutional Review Committee, 2000. Ma Te Rango Te Waka, Ka Rere. The Report of the Ngati Kahungunu Constitutional Review Committee. Hastings: Ngati Kahungunu Iwi Incorporated.

Ngāti Kahungunu Iwi Incorporated, n.d. Communications. [Internet.] [Retrieved 16 November 2009.] Available from: http://www.kahungunu.iwi.nz/index2.html. n.d. Kahungunu 2026 Vision Plan. [Internet.] [Retrieved 16 November 2009.] Available from: http://www.kahungunu.iwi.nz/index2.html. n.d. Kahungunu 2026 Vision Plan - Culturally Strong. [Internet.] [Retrieved 16 November 2009.] Available from: http://www.kahungunu.iwi.nz/index2.html. n.d. Kahungunu 2026 Vision Plan - Making our Mark. [Internet.] [Retrieved 16 November 2009.] Available from: http://www.kahungunu.iwi.nz/index2.html. n.d. Kahungunu 2026 Vision Plan - Participating Citizens of the World. [Internet.] [Retrieved 16 November 2009.] Available from: http://www.kahungunu.iwi.nz/index2.html. n.d. Kahungunu 2026 Vision Plan - Tinorangatiratanga. [Internet.] [Retrieved 16 November 2009.] Available from: http://www.kahungunu.iwi.nz/index2.html. n.d. Registration. [Internet.] [Retrieved 16 November 2009.] Available from: http://www.kahungunu.iwi.nz/index2.html. n.d. Taurahere. [Internet.] [Retrieved 16 November 2009.] Available from: http://www.kahungunu.iwi.nz/index2.html.

n.d. Tïhei Kahungunu. [Internet.] [Retrieved 16 November 2009.] Available from: http://www.kahungunu.iwi.nz/index2.html. 2006. Constitution of Ngati Kahungunu Iwi Incorporated. Hastings: Ngāti Kahungunu Iwi Incorporated.

Nikora, Linda Waimarie, Bernard Guerin, Mohi Rua and Ngahuia Te Awekotuku, 2004. Moving Away From Home: Some Social Consequences for Tūhoe Migrating to the Waikato. New Zealand Ppulation Review. 20(1\&2):93-109.

O’Regan, Hana, 2001. Ko Tahu, Ko Au: Käi Tahu Tribal Identity. Christchurch: Horomaka.

Pere, Rangimarie Turuki, 1991. Te Wheke: A Celebration of Infinite Wisdom. Gisborne: Ao Ako Global Learning. 
Poata-Smith, E. S. Te Ahu, 2004, The Changing Contours of Maori Identity and the Treaty Settlement Process. In Janine Hayward and Nicola Wheen (eds), The Waitangi Tribunal. Wellington: Bridget Willieams Books, pp.165-183.

Roberts, Jude, 2006. Layer Upon Layer - Whakapapa. Cambridge: Wotz Wot.

Sardar, Ziauddin and Borin Van Loon, 2004. Introducing Cultural Studies. Royston: Icon Books.

Schiller, Nina Glick, 2005. Long-Distance Nationalism. In Melvin Ember, Carol R. Ember, and Ian Skoggard (eds), Encyclopedia of Diasporas: Immigrant and Refugee Cultures Around the World. Vol. I: Overview and Topics. Yale: Springer, pp.570-580.

Simpson, Mīria, Patrick Parsons, Ngāti Kahungunu Iwi Incorporated and National Library of New Zealand, 2003. Ngā Taumata: A Portrait of Ngāti Kahungunu He Whakaahua o Ngāti Kahungunu 1870 - 1906. Wellington: Huia, National Library of New Zealand and Ngāti Kahungunu Iwi Incorporated.

Slack, Jennifer Daryl, 1996. The Theory and Method of Articulation in Cultural Studies. In David Morley and Kuan-Hsing Chen (ed.), Stuart Hall: Critical Dialogues in Cultural Studies. London: Routledge, pp.112-127.

Smith, Jonathan A., Paul Flowers and Michael Larkin, 2009. Interpretative Phenomenological Analysis: Theory, Method and Research. London: Sage.

Smith, Linda Tuhiwai, 1999. Decolonizing Methodologies. Research and Indigenous Peoples. London: Zed.

Smith,Takirirangi, 2007. Whakapapa Korero, Tangata Whenua and Turangawaewae: A Case Study of the Colonisation of Indigenous Knowledge. Unpublished Ph.D. thesis, University of Auckland.

Soja, Edward,1996. Thirdspace: Journeys to Los Angeles and Other Real-And-Imagined Places. Cambridge: Blackwell.

Spivak, Gayatri Chakravorty, 1999. A Critique of Postcolonial Reason: Toward a History of the Vanishing Present. Cambridge: Harvard.

Statistics New Zealand, n.d. Iwi - New Zealand Standard Classification. [Internet.] [Retrieved 10 April 2010.] Available from: 
http://www2.stats.govt.nz/domino/external/Web/carsweb.nsf/94772cd5918085044 c2567e6007eec2c/24c382c1c1d4ba31cc256a41007d0cd6?OpenDocument. 2001. New Zealand: An Urban/Rural Profile. [Internet.] [Retrieved 20 March 2010.] Available from:

http://www.stats.govt.nz/Publications/BusinessPerformanceEnergyAndAgricultur e/urban-rural-profile.aspx.

2006. Iwi (total responses) by regional council for the Māori descent population, 2006 Census. [Internet.] [Retrieved 19 May 2010.] Available from:

http://www.stats.govt.nz/Census/2006CensusHomePage/QuickStats/quickstatsabout-a-subject/maori.aspx. 2008. Iwi Profiles: Ngāti Kahungunu, 2006 Census. [internet.] [Retrieved 8 June 2010.] Available from: http://www.stats.govt.nz/Census/about-2006-census/iwiprofiles/2006-census-iwi-profiles.aspx.

Stevenson, Brendan, 2004. Te Hoe Nuku Roa: A Measure of Cultural Identity. He Pukenga Kōrero: A Journal of Māori Studies, 8(1):37-46.

Straus, Terry and Debra Valentino, 2001. Retribalization in Urban Indian Communities. In Susan Lobo and Kurt Peters (eds), American Indians and the Urban Experience. Walnut Creek: AltaMira Press, pp.85-95.

Sullivan, Courtney, 2008. Mai i Aotearoa: The effects of living in Australia on Māori identity. Unpublished Honours dissertation, University of Otago.

Swadener, Beth Blue and Kagendo Mutua, 2008. Decolonizing Performances: Deconstructing the Global Postcolonial. In Norman K. Denzin, Yvonna S. Lincoln and Linda Tuhiwai Smith (eds), Handbook of Indigenous and Critical Methodologies. Los Angeles: Sage, pp.31-43.

Teaiwa, Teresia K., 2001. L(o)osing the Edge. The Contemporary Pacific, 13(2):343357. 2010. Discussion on Articulation Theory. [Conversation.] (Personal communication, 29 April 2010).

Te Puni Kōkiri, 2009. Kahungunu Passport and CD. In Kōkiri, Issue 15:25. 
Te Rūnanga o Ngāti Awa, 2005. Charter of Te Runanga o Ngati Awa. [Electronic Report.] [Retrieved 30 September 2008.] Available from: http://www.ngatiawa.iwi.nz/cms/view/runanga-operations.aspx.

Te Runanga o Ngati Kahungunu ki te Whanganui a Tara, 2008. Draft Strategic Plan 2008. [Unpublished report.] Wellinton: Te Rūnanga o Ngāti Kahungunu ki Te Whanganu-a-Tara.

Te Whenua, Toitu, 1959. The Struggle Against Fragmentation. In Te Ao Hou. The New World, 28:43-47. [Retrieved 4 April 2010.] Available from: http://teaohou.natlib.govt.nz/journals/teaohou/issue/Mao28TeA/c21.html.

Tomoana, Ngahiwi, 2009. Mihimihi. In Hoea rā: Iwi Newsletter Matariki Edition 2009. [Internet.] [Retrieved 08 September 2009.] Available from: http://www.kahungunu.iwi.nz/index2.html.

Treaty of Waitangi (Fisheries Claims) Settlement Act 1992.

Trujano, Carlos Yescas Angeles, 2008. Indigenous Routes: A Framework for Indigenous Migration. Geneva: International Organization for Migration.

van Meijl, Toon, 1995. Maori Social-Political Organisation in Pre- and Proto-History: On the evolution of post-colonial constructs. Oceania, 65(4):304-22. 2006. Multiple identifications and the dialogical self: urban Maori youngsters and the cultural renaissance. Journal of the Royal Anthropological Institute, 12:917933.

Wacquant, Loïc J.D., 1992. Toward a Social Praxeology: The Structure and Logic of Bourdieu's Sociology. In Pierre Bourdieu and Loïc J.D. Wacquant (eds), Invitation to Reflexive Sociology. Chicago: University of Chicago Press, pp.1-59. Waitangi Tribunal Report, 1998. Te Whanau O Waipareira report, WAI 414. Wellington: GP.

Walker, Ranginui, 1982. Development From Below: Institutional Transformation in a Plural Society. In Ian Shirley (ed.), Development Tracks. Palmerston North: The Dunmore Press, pp.69-89. 1989. Maori Identity. In David Novitz and Bill Willmott (eds), Culture and Identity in New Zealand. Wellington: GP, pp.35-52. 
Ward, Alan and Janine Hayward, 1999. Tino Rangatiratanga - Māori in the Political and Administrative System. In Paul Havemann, Indigenous People's Rights in Australia, Canada and New Zealand. Oxford: Oxford University Press, pp.37899.

Watts, Michael John, 1999. Collective Wish Images: Geographical Imaginaries and the Crisis of National Development. In Doreen Massey, John Allen and Philip Sarre (eds), Human Geography Today. Cambridge: Polity, pp.85-107.

Webster, Steven, 1998. Patrons of Maori Culture: Power, theory and ideology in the Maori Renaissance. Dunedin: University of Otago.

Whaanga, Mere, n.d. Ngāti Kahungunu tribal area. [Internet.] [Retrieved 20 March 2010.] Available at: http://www.teara.govt.nz/en/ngati-kahungunu/1/1.

Whimp, Graeme, 2008. Interdisciplinarity and Pacific Studies: Roots and Routes. The Contemporary Pacific. 20(2): 397-421.

Williams, Raymond, 1989. Resources of Hope: Culture, Democracy, Socialism. London: Verso.

Winitana, Mei, 2008. [Electronic Journal.] Contemporary perceptions of mana wahine Māori in Australia: A diasporic discussion. MAI Review. 3(Research Notes 4):1-8. [Retrieved 9 December 2009.] Available from: http://www.review.mai.ac.nz/index.php/MR/issue/view/11.

Woodward, Kath, 2002. Understanding Identity. London: Arnold.

Young, Raymond, 1998. Pathways as Metaphors of Movement: A Study of Place, Mobility and Embodiment in Fiji. Unpublished Ph.D. thesis, Victoria University of Wellington.

\section{Interviews}

AT Ada Tangiora, 2009. Interview, September. Wellington.

Bill Te Huia Hamilton, 2009. Interview, September. Wellington.

Cellia Joe, 2009. Interview, August. Wellington.

Challen Wilson, 2009. Interview, August. Wellington.

Jamee Maaka, 2009. Interview, August. Wellington.

Jorgette Maaka, 2009. Interview, September. Wellington.

Lisa Lewis, 2009. Interview, August. Wellington. 
Piri Sciascia, 2009. Interview, November. Wellington.

Tamati Olsen, 2009. Interview, October. Wellington.

Te Hiwi Preston, 2009. Interview, August. Wellington. 


\section{Appendix A}

\section{$\underline{\text { Ngāti Kahungunu Tribal Area }}$}

This map shows the main areas of the Kahungunu rohe, highlighting Wairoa (North), Heretaunga (Central) and Wairarapa (South). The map is from Mere Whaanga and can be found at Te Ara - the Encyclopedia of New Zealand website.

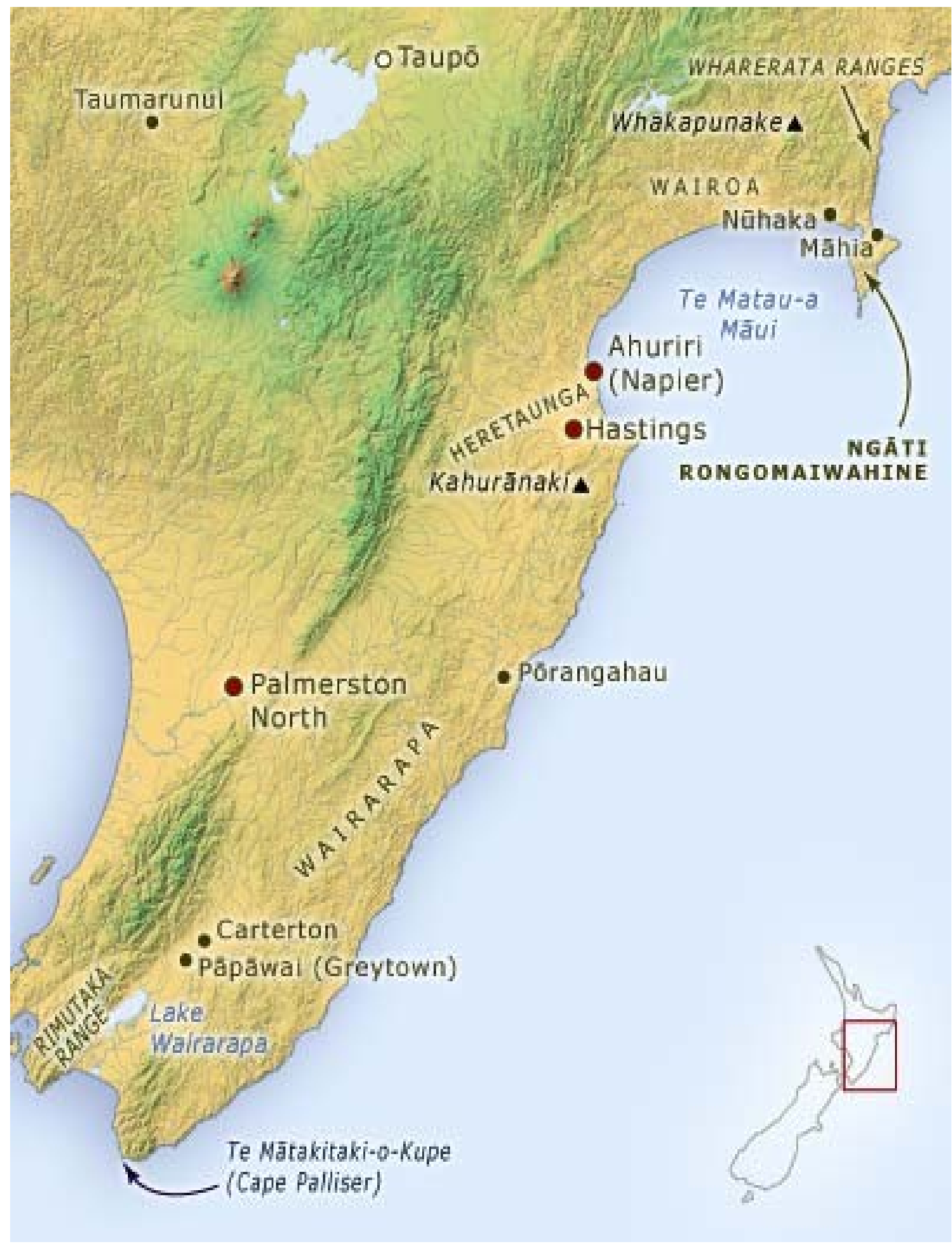




\section{Appendix B}

TE WHARE WANANGA O TE ÜPOKO O TE IKA A MĀUI

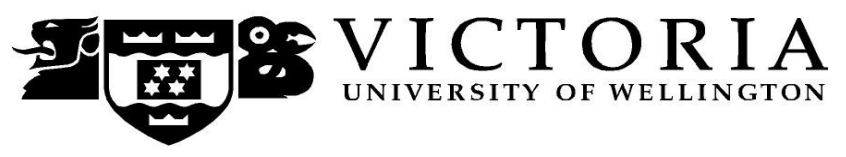
MEMORANDUM
Phone 0-4-463 5827
Fax 0-4-4635209
Email_Jenny.neale@vuw.ac.nz

\begin{tabular}{|c|c|}
\hline TO & Christina Gonzalez \\
\hline $\begin{array}{l}\text { COP } \\
\text { Y TO }\end{array}$ & Maria Bargh \\
\hline $\begin{array}{l}\text { FRO } \\
\text { M }\end{array}$ & Dr Jenny Neale, Acting Convener, Human Ethics Committee \\
\hline DATE & September 19, 2008 \\
\hline $\begin{array}{l}\text { PAGE } \\
\mathrm{S}\end{array}$ & 1 \\
\hline $\begin{array}{l}\text { SUBJ } \\
\text { ECT }\end{array}$ & $\begin{array}{l}\text { Ethics Approval } 15873 \text { Contextualizing Urban Indigeneity in } \\
\text { Maori-State Relations }\end{array}$ \\
\hline
\end{tabular}

Thank you for your application for ethical approval, which has now been considered by the Standing Committee of the Human Ethics Committee.

Your application has been approved from the above date and this approval continues until December 31 2009. If your data collection is not completed by this date you should apply to the Human Ethics Committee for an extension to this approval.

Best wishes with the research.

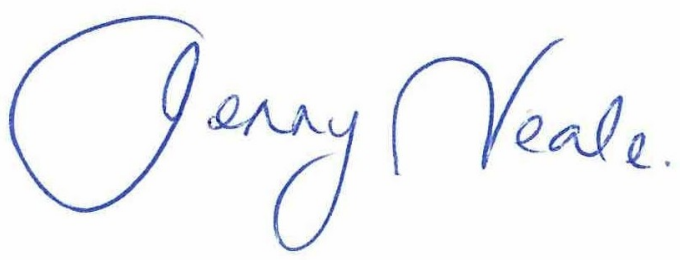

Jenny Neale

Acting Convener 


\section{Appendix C}

VICTORIA UNIVERSITY OF WELLINGTON

Te Whare Wananga o te Upoko o te Ika a Maui

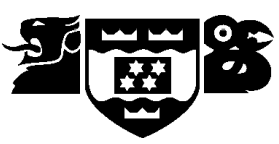

Faculty of Humanities and Social Sciences

\section{QUESTIONNAIRE SHEET}

Researcher: Christina González

Supervisors: Dr. Maria Bargh and Dr. Roger Maaka

Masters Thesis, VUW: Being Ngāti Kahungunu in the City: Māori Social Organisation in Wellington

PLEASE PRINT CLEARLY THE REQUESTED INFORMATION BELOW:

Name:

Email:

Mobile:

PLEASE ANSWER THE FOLLOWING QUESTIONS BY CHECKING THE BOX OR FILLING-IN THE BLANK SPACE:

1) What is your gender? $\quad \square \quad$ Female $\quad \square \quad$ Male

2) What is your age?

3) What is your profession?

4) To which iwi (region specific e.g. Ngāti Kahungunu ki Wairoa) and hapū do you selfidentify?

5) What other, if any, ethnic groups do you affiliate to?

6) What town(s) or city(-ies) were you raised in (between the ages of 0 to 18)?

7) Where have you lived throughout Aotearoa New Zealand? 
8a) Have you lived overseas? $\quad \square \quad$ No $\quad \square \quad$ Yes

8b) If so, where have you lived?

9) For how many years have you resided in Wellington?

10) Would you self-identify as Wellingtonian? $\quad \square \quad$ No $\quad \square \quad$ Yes

11) Do you self-identify as urban (in whatever way you understand the term)?

$\square$ No $\quad \square \quad$ Yes

12) Are you a registered member of Ngāti Kahungunu Iwi Incorporated?

$\square \quad$ No $\quad \square \quad$ Yes

13) Are you a registered member of Ngāti Kahungunu Embassy (in Wellington)?

$\square \quad$ No $\quad \square \quad$ Yes

14a) Are you a member of any Māori cultural groups and/or socio-political institutions

$\square$ No $\quad \square \quad$ Yes

14b) If so, to which groups do you affiliate?

15) Are you interesting in participating in a face-to-face interview concerning Ngāti

Kahungunu identity in Wellington during the month of August, 2009?

No $\quad \square \quad$ Yes

16) Do you have an interview-style preference?

One-on-one interview

Joint interview ( 2 interviewees, simultaneously)

Focus group (2+ interviewees, simultaneously)

No preference

NGA MIHI KI A KOE 


\title{
Appendix D
}

\author{
VICTORIA UNIVERSITY OF WELLINGTON \\ Te Whare Wananga o te Upoko o te Ika a Maui
}

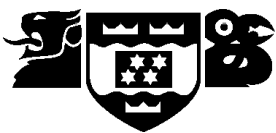

Faculty of Humanities and Social Sciences

\section{PARTICIPANT INFORMATION SHEET}

Researcher: Christina González

Supervisors: Dr. Maria Bargh and Dr. Roger Maaka

Masters Thesis, VUW: Being Ngāti Kahungunu in the City: Māori Social Organisation in Wellington

Tēnā koe,

I am Puerto Rican (Boriqua) from the Bronx and Brooklyn in New York City. Currently, I am enrolled as a Masters student in Māori Studies at Victoria University of Wellington (VUW) to undergo thesis research on Ngāti Kahungunu identity in Wellington. My work seeks to understand how some Kahungunu articulate, transform and/or maintain their identity while living away from their tribal lands, in Wellington. Because I am a daughter of an immigrant mother, indigenous to the island-nation of Puerto Rico, a colony of the United States, I personally understand the effects of colonisation and diaspora upon one's lived culture, and the social mobility and organisation that ensue.

This project is motivated by a commitment to understand the realities lived by Indigenous and historically colonised peoples from within an urban, non-traditional setting in order to deepen understandings of ourselves within contemporary contexts and to strengthen relations within and between our communities. I hope that my study contributes to Ngāti Kahungunu by sharing the contextual experiences of their tribal identities, and by unraveling particular themes and possible patterns to encourage greater reflection on the way that representation unfolds intra-tribally.

I am guided by methodologies and research ethics which mean I will take care that the interview is conducted in a culturally sensitive and morally appropriate manner. I sought and received Human Ethics Approval from VUW to interview you for the purposes set out by this project.

My thesis is divided into two main parts:

1) Individual understandings and expressions of Ngāti Kahungunu cultural identity in Wellington, and

2) Collective articulations of Ngāti Kahungunutanga through social groupings such as the Ngāti Kahungunu Embassy. 
The information that will be elicited will concern your life as Ngāti Kahungunu, as experienced in Wellington. The questionnaire sheet you fill out will help me better prepare for and tailor the interview for you, although it will be guided by broad themes and specific, open-ended questions. The thesis will probe and explore identity through the following topics:

1) Migration and/or diaspora,

2) Being Māori,

3) Being Ngāti Kahungunu,

4) Living as 'urban' or Wellingtonian,

5) Inter-hapū and pan-tribal/inter-tribal relations, and

6) Socio-political representation.

Should you be interested in collaborating in my project, I will arrange a time and location that is suitable for you to have a one-on-one interview that will last anywhere between 60 to 90 minutes. The session will be recorded using a portable digital voice recorder. The recorder will be used so that I may review and transcribe the information. I will securely store the recorded interviews for a period of no longer than three years from the time of documentation in a password-sensitive computer. Afterwards, I will destroy the material or return it to you. Only my two academic supervisors and I will have access to the interviews. The information gathered from the interviews will be used for both community and scholarly purposes; to analyse for the thesis and present to the Ngāti Kahungunu community and to (Maori) academics. With any information produced and released, you do have a choice in being named/ identified.

Finally, should you feel at any time the need to withdraw from this study, you may do so at any time before the data has been analysed; more specifically, anytime two to three weeks after the interview. You do not have to provide any reasons or explanations for your termination. In addition, you have the opportunity to review audio transcripts before I begin to assess them.

Thank you for your time and interest in this study. If you have any questions, concerns or would like further information in regards to this project, please do not hesitate to contact myself or my supervisors:

Researcher:

Email:

Phone:

Supervisor:

Email:

Phone:

Supervisor:

Email:

Phone:
Christina González

christinamarie.gonzalez@gmail.com

0-21-134-4365

Dr. Maria Bargh (Lecturer of Māori Studies at VUW)

maria.bargh@vuw.ac.nz

0-4-463-5465

Dr. Roger Maaka (Dean of Māori Studies at EIT)

rmaaka@eit.ac.nz

0-6-974-8888 ext-5488 


\section{Appendix E \\ VICTORIA UNIVERSITY OF WELLINGTON \\ Te Whare Wananga o te Upoko o te Ika a Maui}

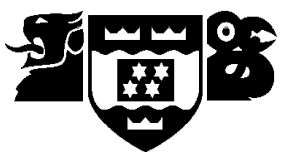

Faculty of Humanities and Social Sciences

\section{PARTICIPANT CONSENT FORM}

Researcher: Christina González

Supervisors: Dr. Maria Bargh and Dr. Roger Maaka

Masters Thesis, VUW: Being Ngāti Kahungunu in the City: Māori Social Organisation in Wellington

I have been prepared with information about the content and purpose of the study in which I am partaking, as well as the role the information I provide might serve. I was given an opportunity to pose questions in regards to the research and have them addressed by the researcher (Christina González) clearly and to my satisfaction. I have the right to withdrawal my participation from the project, before initiation of data analysis.

I understand that the interview will be conducted using a portable digital voice recorder so that the information can be transcribed later into written form. The data provided will only be utilised by the researcher, although her supervisors (Dr. Maria Bargh and Dr. Roger Maka) may have access to it so as to provide assistance to her in the process of analysis.

It has been brought to my attention that after three years time, the electronically recorded information I supplied will be destroyed or returned to me (upon request).

I am aware that my participation in this research is strictly voluntary. Additionally, because the interview is confidential, I understand that my identity will not be revealed (unless otherwise noted by the participant) in any published work(s) done by the researcher.

I understand that I can request a summary of the work and its results upon completion from the researcher.

Please Circle

I consent to have the interview recorded using a voice recorder.

Y N

I understand that the opinions that I provide in this interview will be used in the study and may be published. 
I would appreciate receiving a summary of the research.

After three years time, I would like all material from my interview to be destroyed. Y N

After three years time, I would like all evidence of my interview to be returned to me. Y N

I agree to being identified (i.e. name) in published works by the researcher. Y N

I agree to all the conditions set out in this consent form.

Y N

I agree to participate in this project.

Y N

Signed:

Name of Participant:

\section{(Please print clearly)}

Date:

Email:

Postal Address:

Daytime Phone:

Researcher:

Christina González

Email:

christinamarie.gonzalez@gmail.com

Phone:

0-21-134-4365

Supervisor:

Email:

Phone:

Dr. Maria Bargh (Lecturer of Māori Studies at VUW) maria.bargh@,vuw.ac.nz 0-4-463-5465

Supervisor:

Dr. Roger Maaka (Dean of Māori Studies at EIT)

Email:

Phone: rmaaka@eit.ac.nz 0-6-974-8888 ext-5488 